\title{
Local David Versus Global Goliath: Populist Parties and the Decline of Progressive Politics in Italy*
}

\author{
Matteo Cavallaro ${ }^{\dagger}$
}

\author{
Working Paper No. 144
}

\author{
January $9^{\text {th }}, 2021$
}

\begin{abstract}
This paper analyzes the role of local spending, particularly on social welfare, and local inequality as factors in the Italian political crisis following the adoption in 2011 of more radical national austerity measures. We employ two different methods. First, we develop an original database of municipal budgets. There we show that even the lowest level of social welfare spending, that offered by Italian municipalities, though also hit by austerity, was still able to moderate this national shock. We test three operationalizations of local spending: aggregate current expenditures, aggregate current expenditures on social services, and current expenditures disaggregated by function. We show that municipal current expenditures, particularly on social spending, significantly affected the post-2011 share of votes for the progressive coalition. The results also show that social spending, especially on education, significantly moderated the combined effect of national austerity and the economic crisis on voting for populist radical right parties, while no significant results appeared for populist parties in general. Local inequality appears to significantly enhance vote shares of populist radical right parties and populist parties in general. We caution that, although significant, the effect is not strong: that local policy and economic conditions can moderate national shocks but cannot reverse them.
\end{abstract}

\footnotetext{
* I am grateful for useful comments from Thomas Ferguson, David Flacher, and participants at the Trento Economics Festival in 2018. Thanks also to the Institute for New Economic Thinking for financial support.

$\dagger$ Post-doc researcher, University of Lausanne.
} 
The second analysis relies on survey data to ascertain the individual-level mechanisms behind the role of local welfare. The paper argues that local economic inputs influence voters' position on non-economic issues. Our results, however, do not identify any significant individual-level channel of transmission, be it cultural or economic.

\section{https://doi.org/10.36687/inetwp144}

JEL codes: D72, H72, P16

Key words: populism, austerity, political change, elections, inequality and distribution 


\section{Introduction}

In the western world, the decade since the great financial crisis is characterized by high political volatility, the dealignment and realignment of many political systems, and, in general, a populist Zeitgeist (Mudde and Kaltwasser 2017). Italy is one country where all of these processes hit harder than elsewhere. The party system reborn at the beginning of 1990s has significantly changed and, as we will argue, is now characterized by an unstable populist ascendency in which differing versions of populism contend with one another (see Section 2). Following the 2018 parliamentary election, the two main (populist) ${ }^{1}$ parties that did the best by comparison to 2013, the Movimento 5 Stelle (Five-star Movement - M5S hereafter) and the radical right Lega (the League) ${ }^{2}$ joined forces and launched what they called a Governo del Cambiamento ("Government of the Change").

This is not the first time that populist parties entered national governments - Italy, Austria, and the Netherlands all had populist parties as part of governing coalitions in the last 25 years - but these usually happened in coalition with some non-ideologically populist parties. As such the alliance between the M5S and the League was the first 'fully populist' government in the Old Continent. The alliance was short-lived: the government ended in August 2019, after just one year, and the M5S found a new ally in the center-left Partito Democratico (Democratic Party - PD from now on).

But since the 2007-2009 economic crisis and the acceleration of austerity policy in 2011 Italian elections show a remarkably strong presence of populist parties, as we can see in Figure 1 that summarizes the electoral performances of different party families since 2006.

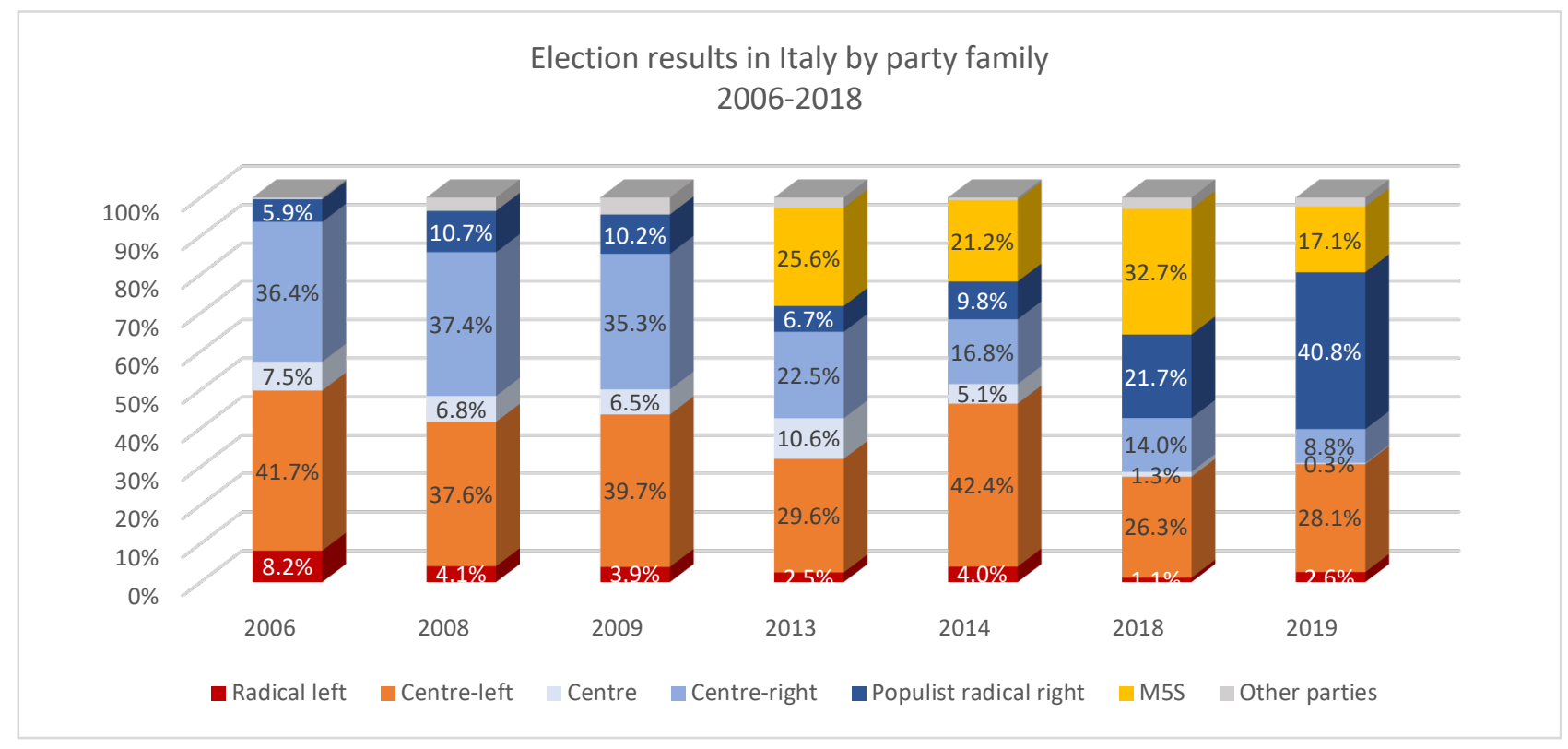

Figure 1. Election results by party family between 2006-2018

\footnotetext{
${ }^{1}$ While, as we will see, the definition of populism is still debated, there is no debate on the populist nature of the two political forces that ran Italy between 2018 and 2019 (Mudde and Kaltwasser 2017).

${ }^{2}$ No longer 'Northern League' following the rise of Matteo Salvini as party leader.
} 
Italy appears as a stronghold for populist movements, in particular of the right, with an important role reserved to the Five Star Movement, a political actor that is neither clearly right-wing nor left-wing (Conti and Memoli 2015; Bordignon and Ceccarini 2013). At the same time, the country that, during the 70s, had the strongest Communist party in Western Europe, sees leftist forces at their lowest point following the 2018 Parliamentary elections. Much like what we saw elsewhere (e.g. 2016 US presidential election, when the Democrats lost in the Midwest while obtaining their best results since 1936 in California), the decrease of center-left and social-democratic forces was uneven. The map of the 2018 election differed markedly from the usual electoral geography that characterized the Italian Second Republic up to then, as the center-left gained in the more affluent cities by comparison with previous elections. This shift is widely regarded as the latest development of a longer-term realignment of Italian politics (Cavallaro, Diamanti, and Pregliasco 2018).

The evidence of the importance of the economic crisis of 2008-09 in triggering all this is compelling, as Figure 1 suggests. The rise of populist forces and the crisis of Italian progressives seem to start just after the economic crisis of 2008-2009. This process closely resembles that of other countries and, not surprisingly, sharply different explanations have been proposed to understand this shift. Debates between economic and cultural approaches are currently intense (see section 3). Among the economic readings of the phenomenon, different authors point to the role of economic modernization, either in terms of automation of production (Im et al. 2019) or international trade (Colantone and Stanig 2018; Malgouyres 2017). In addition, an important recent line of inquiry relates to the role of the welfare state: as trade creates winners and losers, redistribution is posited to be a key element mitigating the differences between the two (Rodrik 1997). However, another consequence of increased trade openness, according to Rodrik (1997) is that it becomes harder to compensate people's losses since capital becomes increasingly mobile, heading towards countries/regions with lower levels of taxation. As a consequence, national governments have increasing trouble financing social security and redistribution.

During the 2007-2009 economic crisis a common reaction across the Western world was to adopt austerity policies and fiscal consolidation. Instead of remedying the distributional conflict opened by globalization (and other factors of modernization, such as automation), the combination of the Great Recession and austerity probably contributed to the rise of income inequality in the western world (Ball et al.2013; Woo et al.2013). The political crisis that different western countries experienced, with the rise of populist parties of various kinds and the crisis of established (and, in particular, social democratic) parties, could be linked to such conflict, as inequality increased as a result of financial globalization (Jaumotte, Lall, and Papageorgiou 2013; Furceri 2015). On this reading, the "losers of modernization"3 (Rydgren 2007), often identified with industrial workers and less educated people, feel left behind by their national governments and turn to populist parties. At the same time, social democratic and progressive forces face an uneasy strategic decision between losing their

\footnotetext{
${ }^{3}$ The literature has a wide definition of "losers": they could be so in absolute or relative terms and it could also simply be a perception rather than a real "loss".
} 
historic core electorate and making inroads into the new generations and progressive parts of the "winners" (Abou-Chadi and Wagner 2020; Rennwald 2020).

If recent changes experienced by western political systems are effectively linked to a distributional conflict, then one could expect redistributive policies, and notably social welfare spending, to act as moderators and inequality as an enhancer of crises. In other words, we can imagine the welfare state as a parachute for all those that saw their social status worsened (in relative or absolute terms) or menaced by the globalized economy. By cutting this parachute, Western governments increased the anxiety and frustration that is commonly identified as a core element for populist sentiments, especially on the right (Rydgren 2013).

In this context, the Italian political system would appear to be an important case study. Italy too experienced major austerity measures (see Section 4) and, as previously noted, the end of the Second Republic coincides with the accelerated fiscal consolidation decided by Monti's government in 2011, and supported in Parliament by parties of both the center-left and the center-right. The most vehement opposition were those parties that the literature tends to identify as populist. Indeed, within a single country, the shock represented by austerity measures on national welfare is mostly national and therefore fairly evenly distributed across the country. As such it appears desirable to test the general idea that more redistribution and lower inequality could counteract the crisis of left-wing parties and the rise of populist forces. In other words, we want to see if David, that is local welfare and a more equal local economic environment, could, if not kill, at least slow down Goliath, the combination of the Great Recession and national austerity measures.

Given the problems of testing hypotheses on a national scale, we reversed our reasoning from head to toe: if redistribution and equality are indeed a parachute able to moderate the political crisis that followed the one - two punch of austerity and the Great Recession, then even the smallest of parachutes, local welfare and the local economic environment, might act as a moderator, slowing down the process that in many countries has led to the crisis of social democratic forces with the rise of populist parties. ${ }^{4}$

Once again, the Italian system offers an interesting opportunity to test this hypothesis as it has various forms of local welfare that vary between regions and municipalities and whose extensions differ across the country. Moreover, cuts to local government funding were an integral part of the austerity measures implemented after the 2007-2009 crisis. But the cuts were not applied everywhere as municipalities prioritized different forms of social spending. Indeed, each area adjusted to the shocks represented by austerity and the crisis in its own way. ${ }^{5}$ In a national economic environment characterized by the implementation of austerity measures, how municipalities adapted their strategies might help explain the new geography:

\footnotetext{
${ }^{4}$ As we will see in section 5, operationalizing what "local" means is not always obvious. By local economic environment we mean an area where a voter most likely spends the majority of her time and has most of her social interactions. As we will see when discussing our data, Italy offers an interesting statistical case to operationalize such a concept.

${ }^{5}$ Both austerity and the economic crisis have as a consequence a decrease in the available funding, either because of lower transfers or in the form of lower receipts from taxation.
} 
local welfare could have acted as a moderator, slowing down the national dynamics that promoted the of populist parties and the troubling decline of center-left forces.

In this paper we test how local economic policy was able to lessen the national dynamics in the context of post-crisis Italy. In doing so, we rely on an original collection of budgetary data of Italian municipalities covering the 2006-2019 period as well as on survey data obtained through a survey developed for 2019 European elections.

The article is structured as follows: we outline the main features of the post-crisis Italian political system in section 2 and highlight the main concerns of our paper: the crisis of the Italian center-left and the rise of populist forces. In section 3 we sort through the main explanations for this worldwide phenomenon and we derive our hypotheses that relate to the role of local welfare and local inequality. In section 4 we summarize the main characteristics of Italian austerity and how it affected local spending. Section 5 describes the dataset and the main choices in the construction of our variables, while section 6 reviews our methodology. In section 7 we set out the results and assess our hypotheses. Finally, we discuss the implications of our findings and point out the limitations of this study in section 8 .

\section{The Italian political system after the Great Recession: an unstable populist ascendency in the context of a crisis of progressive parties}

In this section, we briefly review the most recent evolution of the Italian political system and trace the key turning points that eventually led Italy to become an 'unstable populist ascendency'.

\subsection{The Italian political system comes in from the cold.}

Before the 1990s, the Italian political system appeared as a fairly good example of the frozen systems discussed by Lipset and Rokkan (1967). The party system was centered around one major actor, the Democrazia Cristiana that was able to stay in power for almost fifty years. The end of the Cold War provoked a first thaw in the Italian political landscape and brought about the end of the so-called First Republic. Before the birth of the Second Republic, the country experienced a transition period in which power was in the hands of 'technocratic' governments; at the same time new actors emerged (the center-right Forza Italia led by Silvio Berlusconi, the radical right secessionist Lega Nord) while older parties took the chance to profoundly change their ideological appeal (the Communist Party turned into the Partito Democratico della Sinistra in 1991 while the neo-fascist Movimento Sociale Italiano joined the center-right and toned town its more nostalgic tones, becoming Alleanza Nazionale). The Italian Second Republic was clearly different from the previous one and was characterized by a bipolar political system and alteration between center-left and center-right. This lasted until the economic crisis of 2007-2009. In a context of high uncertainty and ever-increasing interest rates looming on the large Italian public debt, in 2011 center-left and center-right parties reached a parliamentary agreement to support a new 'technocratic' cabinet led Mario Monti. Unbeknownst to many at the time, the Second Republic died, and a new transition period followed. 


\subsection{The birth of an imperfect tripolar system and the unstable populist hegemony}

In the wake of the Great Recession and the adoption of austerity measures, the Italian political system experienced a troubled period as it abandoned the bipolar configuration of the 1994-2008 Second Republic to enter years of high electoral volatility (Chiaramonte et al. 2018). In the 2013 parliamentary elections a new actor, the populist ${ }^{6}$ M5S ("Five Star") party emerged between center-left and center-right and obtained a plurality of the votes in the country. As no coalition was able to obtain a parliamentary majority, the center-left allied with part of the center-right, a choice that would lead to three different cabinets, all with members of the center-left PD. As Berlusconi's Forza Italia was initially part of this renewed bipartisan alliance, the only political forces consistently in opposition since 2011 were the two main populist parties: the League and the M5S. The results of the Italian elections on March $4^{\text {th }}, 2018$ saw these forces emerge as the main winners, while the center-left alliance obtained its worst electoral vote in the history of the Republic. As no coalition was able to obtain a parliamentary majority, an agreement between former competitors had to be found. This led to the experiment of the first 'full'-populist government with the M5S and the League joining forces in a cabinet led by Giuseppe Conte, considered to be close to the M5S. The experiment was, however, short-lived and ended in the summer of 2019. Since then Italy has been run by a new coalition built around the M5S and the PD.

To summarize, the post-crisis Italian political system is characterized by an imperfect tripolarism (Diamanti 2016; Chiaramonte and Emanuele 2013), with two major poles represented by the center-right and, interchangeably depending on the moment, the Five Star Movement and the center-left. As noted by Oesch and Rennwald (2018,1), tripolarism seems to be a prerogative of national politics in Europe in the twenty-first century, though it has appeared with varying degrees of quickness. According to the authors, a feature of these political systems is that: "The two dominant poles of the 20th century, the parties of the left and center-right, are faced with a third pole, that of the radical right." This arrangement partially corresponds to the Italian situation. Three diverging factors deserve to underlined: (i) the party that can be most easily associated with the "radical right", the League, is an integral part of the center-right coalition, (ii) it is difficult to place the M5S within the main political branches in Europe; it represents a pole of its own, and (iii) populist parties in Italy appear stronger than elsewhere. Indeed, the results of the 2019 European elections show that Italy is the Western European country where these forces scored the highest and the only one where they obtained, combined, more than fifty percent of the votes.

As none of the populist actors has a clear and established lead, despite their holding a plurality of the votes in 2013 and a majority in the 2018 and 2019 national elections, we define this period as an unstable populist ascendency: more Italian voters clearly favor these forces, but with no clear and definite winner among them. Within this populist Zeitgeist, progressive forces appear to face a difficult situation. With the exception of the 2014

\footnotetext{
${ }^{6}$ We adopt here the same definition of populism provided by Mudde and Kaltwasser (2017, p.12 ): "a thincentered ideology, which is based not only on the Manichean distinction between 'the pure people' and 'the corrupt elite', but also on the defence of popular sovereignty at any cost".
} 
European election (held during the so-called "honeymoon" after Renzi became Prime Minister in February 2014), the main party of the center-left, the PD, was never able to obtain more than $26 \%$ of the votes, representing its lowest point in pre-crisis Italy. Center-left forces as a whole stayed below the $30 \%$ of the votes in 3 out of 4 national elections. The crisis of progressive parties then appears as the second leg of the current Italian political system. ${ }^{7}$

\subsection{A slowly changing political geography}

The reshaping of Italian political system, with the rise of populist parties and the crisis of progressive forces, has been accompanied by substantial changes in the geographical distribution of voting preferences (Bordignon, Ceccarini, and Diamanti 2018). In particular, compared to 2013 elections, the center-left experienced strong losses in rural areas, while it was actually able to increase its votes in the more affluent city centers of the big and populous cities, as well in those areas with a higher share of people with a tertiary degree (Truglia and Zeli 2020; Cataldi and Emanuele 2013; De Sio 2018). This does not completely reverse Italian political geography: in Table 1 we show the correlation matrix of PD results at the municipal level in the four latest general elections ${ }^{8}$; the connections between 2006 and today's map are still there, but at each election the correlation becomes weaker.

\begin{tabular}{l|lll}
$\begin{array}{l}\text { ELECTION } \\
\text { YEAR }\end{array}$ & $\mathbf{2 0 0 6}$ & $\mathbf{2 0 0 8}$ & $\mathbf{2 0 1 3}$ \\
\hline $\mathbf{2 0 0 6}$ & 1.000 & & \\
$\mathbf{2 0 0 8}$ & 0.8690 & 1.000 & \\
$\mathbf{2 0 1 3}$ & 0.7898 & 0.8146 & 1.000 \\
$\mathbf{2 0 1 8}$ & 0.6270 & 0.6417 & 0.7431 \\
\hline
\end{tabular}

Table 1. Correlation matrix of municipal level results by year for center-left PD.

Changes appear to go in a certain way: the center-left is becoming stronger across those territories inhabited by people usually interpreted as the winners from modernization, while the M5S and the Lega better represent the losers (although of different kinds, see Chiaramonte and De Sio 2019; Levi and Patriarca 2020). Indeed, Italy does not appear to be the only country showing such a pattern and, in a way, it did so later than other countries. In France, the strength of populist radical right parties in formerly pro-communist areas exposed to de-industrialization was already documented in the 1990s by (Perrineau and Mayer 1996). In the UK, Johnston et al. (2018) show how the geographical distribution of voting

\footnotetext{
${ }^{7}$ Interestingly enough, the electoral troubles faced by the PD have not translated in an exclusion from public offices. On the contrary, despite the dip in public support, progressive parties have actually been able to enter different ruling coalitions for 8 years in the last decade, but never following a clear electoral success and mostly because of the instability of the Italian institutional framework.

${ }^{8}$ We stop at 2006 elections because the 2001 electoral system was fairly different from the one in use after the 2005 electoral reform.
} 
preferences has changed since the end of 1980s. Moving to the US, Johnston et al. (2017) argue that, although the map of 2016 Presidential election cannot be regarded as a radical break with previous elections, there are differences worth noticing as the geographical polarization between Democrats and Republicans increased and the "trend towards or away from the Republican norm was significantly influenced by the counties' socio-economic and demographic characteristics, independent of their previous partisan leanings." Among these characteristics, education and the presence of a large minority are both important elements. Van Hamme et al. (2018, 290), in an extended analysis of the evolution of center-left electoral geography in Europe, come to similar conclusions: there is, to a certain level, an hysteresis as historically left places are still more left-leaning than the average, but with important variations indicating a clearly socio-demographically defined trend. In particular, they note that: "most European metropolitan areas are more Left leaning than the country where they are located (and more Left leaning than their affluent suburban areas), and this trend is reinforcing itself. [...] [T] his general conclusion covers important changes in the nature and even the intra-metropolitan geography of the Left, in relation to tertiarization and metropolitanization processes."

As we will see in the next section, socio-economic and demographic factors are at the core of the main explanations for both the rise of populist parties and the crisis of social democracy in the Western world.

\section{Explaining populism's success (and indirectly the crisis of center-left) in a political economy approach: from globalization to the welfare channel}

In the previous section we presented today's Italian political system and argued that it can be interpreted as an unstable populist ascendency. Today's Italian landscape is also characterized by the crisis of its progressive forces and we highlighted a slow but constant change in the country's electoral geography. We now turn to the main literature in political science and economics to understand the main explanations for the changes discussed in section 2 .

\subsection{The unfreezing of Western political systems between economic and cultural} explanations

While recent successes might lead us to consider the rise of populist parties and the crisis of social democratic parties as a very recent phenomenon, other analysts of the restructuring of Western political systems argue that we are in the midst of a long-term process (Inglehart and Norris 2016; Eatwell and Goodwin 2018; Piketty 2018). ${ }^{9}$ Indeed, according to Inglehart and Norris (2016, p. 25), systems experienced a decrease in the relevance of class cleavages as "the electorate had shifted from class-based polarization toward value-based polarization."

\footnotetext{
${ }^{9}$ Interestingly, studies on the re-alignment of political systems almost never focus on social democratic or progressive forces and mainly concern populist parties of the right (little space is dedicated to other populist forces). Still, despite these forces being either absent or in the background, it is possible for us to draw important lessons on the crisis of the center-left too by looking at the extremely rich literature on the rise of right-wing populism.
} 
As such, while in 1960s the political space was mostly structured around economic issues, today post-materialist/cultural issues (the terminology varies across authors) represent the main cleavage. The mechanism behind this restructuring, according to Inglehart and Norris (2016), is deeply rooted in the speed of cultural change between generations that occurred starting from the end of the 1960s coupled with the massification of education. In particular, as far as populist parties are concerned "long-term processes of generational change during the late twentieth century have catalyzed culture wars, for these changes are particularly alarming to the less educated and older groups in these countries. It is not an either/or story, for the two sets of changes may reinforce each other in part, but the evidence in this study suggests that it would be a mistake to attribute the rise of populism directly to economic inequality alone. Psychological factors seem to play a more important role" (Inglehart and Norris 2016, p.30).

There is, however, no clear consensus on Inglehart and Norris' (2016) post-materialist reading. And empirical data too appears to offer ambiguous support for their thesis. Rodrik $(2020,2)$, for example, points out that "observational studies tend to favor the economics argument, while survey experiments give greater credence to culture." While true, it should be noted that the picture coming out of survey analysis is also blurred when it comes to defending the 'cultural backlash' argument. As other studies (Rydgren 2012; Oesch and Rennwald 2018) pointed out, class voting might not have disappeared (as Inglehart and Norris seem to suggest); rather, we are experiencing a change in the way class voting works, with working class voters moving away from social-democratic parties towards populist radical right parties. Indeed, different analyses (Bornschier 2018; Lucassen and Lubbers 2011; Bornschier 2010; Mudde 2007) claim that even in presence of class voting the main drivers concern post-materialist values (e.g. immigration as cultural threat, traditionalism, and identitarianism) rather than materialist (e.g. demand for more redistribution or protectionism).

The conflict between cultural and economic readings of populism, however, is often more apparent than real. Elchardus and Spruyt (2012) note that cultural values can be explained by feelings of deprivation related to one person's economic situation. Ferguson et al. (2020, 120) look at survey data on the 2016 US presidential election and argue that "the social and the economic were intertwined, both in Trump's rhetoric and in the minds of many voters." Similarly, Guiso et al. $(2017,41)$ argue that "populism does not have a cultural cause, but rather an economic insecurity cause, with an important and traceable cultural channel." Using survey data, they show the presence of a strong indirect effect of economic grievances that are drivers for important changes in political trust and in attitudes towards immigration. There would therefore seem to be a channel connecting the economy to voting preferences via cultural values and this channel has become particularly important as globalization strengthened.

\subsection{The role of globalization and economic crises}

A similar approach linking economic and cultural explanations together is also proposed by Piketty (2018). In a study on the evolution of political conflict in Britain, France, and the US, he finds evidence of long-run changes in the main political cleavages. In particular, in the 
1950s-1960s political cleavages and class/income cleavages were extremely close: loweducated and low-income voters disproportionately supported left-wing parties, while the richest half of the population voted for right-wing parties. Today, the system moved to a "multiple-elite" party system "whereby each of the two governing coalitions alternating in power tends to reflect the views and interests of a different elite (intellectual elite vs business elite)" (Piketty 2018,5). Piketty identifies two mechanisms behind this shift: mass-education and globalization. Differently from Inglehart and Norris (2016), the role of education is both "cultural" (i.e. the cognitive instruments provided by education modify an individual's interpretation of the world, regardless of her position in society) and "economic" (i.e. education directly influences an individual's position on the labor market and her exposure to the different processes [trade integration, migration flows, and automatization] that characterize contemporary capitalism [Beramendi and Kitschelt 2016]). As for globalization, the main argument is that, while global trade might have generated positive returns at the aggregate level, these positive gains are not equally spread across the population. This inequality generates 'losers' either in the absolute term (their living standards worsened during the period) or in relative terms (while their living standards improved, they did so at lower rate than the rest of the population).

As a consequence, most of the research on the rise of populist parties focuses on the role of trade. Colantone and Stanig (2018) underline that the rise of right-wing populist (and, generally speaking, nationalistic) feelings is closely related to trade shocks. They do so by analyzing the impact of Chinese import competition on election results at the regional level in 15 European countries between 1988 and 2007, as well as using data from individual-level surveys such as the ESS. They show that right-wing populist parties as well as nationalistic feelings are more likely to increase in those regions that are more exposed to import shocks. They then argue that the core constituency of this "economic nationalism" are the losers from import competition, that they define geographically (or, to use their term, socio-tropically), rather than on class basis, as "not only displaced manufacturing workers in industries most exposed to international competition, but also agents exposed indirectly to the adjustment costs of trade: for instance, residents of manufacturing regions hit by possibly long-term economic decline." (Colantone and Stanig 2018, 11).

Trade is not the only economic element that current research identifies behind the rise of populist (in particular right-wing populist) movements: the role of the 2007-2009 economic crisis, rises in inequality, and the adoption of neoliberal policies have all been proposed as possible explanations. As far as the crisis is concerned, Algan et al. (2017) shows that in post-crisis elections the variation in regional unemployment was a significant predictor of trust in institutions, which is one of the main individual-level predictors of a populist voting preference. These results were confirmed in other studies by Dustman et al. (2017) and Foster and Frieden (2017).

Rising inequality is also often cited as an important factor in explaining the unfreezing of political systems in Western countries. Eichengreen (2018) offers an example of such an approach and, in his accounts of the 2016 US Presidential election and the UK Brexit referendum, he identifies growing economic differences as a major explanatory factor. Pastor 
and Veronesi $(2018,34)$ propose a similar reasoning and argue that "countries with high inequality, high financial development, and trade deficits are especially vulnerable to antiglobal backlash". They then assess their claims in light of the 2016 US Presidential election and conclude that the reasoning seems to fit rather closely what happened.

\subsection{Welfare state reforms and neoliberal policies}

Various studies point also to an active role of neoliberal economic policies (even if many articles do not call them by this name). Jesuit et al. (2009) find a connection between uncompensated labor market shocks and support for the radical right. Vlandas and Halikiopoulou (2016) come to similar conclusions as they focus on the mediating effect of labor market institutions in particular in terms of employment protection legislation (EPL) and unemployment benefits. They analyze the last three European parliamentary elections and find that the presence and intensity of unemployment benefits is a significant predictor of right-wing populist parties support. Unemployment benefits seem to act directly, but also indirectly through limiting the effect of unemployment rates: "where unemployment benefits are generous, unemployment has no association with far right support, but where they are not, unemployment correlates with higher support for the far right. EPL only has an indirect association conditional on unemployment benefits: where unemployment benefits are low, EPL mediates the impact of unemployment; but where unemployment benefits are generous, there is no mediating impact of EPL." (Vlandas and Halikiopoulou 2016, 24). Vlandas and Halikiopoulou's results for unemployment benefits point towards a complex relationship between social protection and the rise of populist parties, in particular populist parties of the right. In line with this approach, Cavaille and Ferwerda (2018) support the existence of a "welfare channel" that shapes the extent of the distributional conflict between native and immigrant population. This channel influences anti-immigrant sentiment by native voters, among the clearest and best-known predictors of populist radical right voting preferences. They therefore hypothesize that the welfare state might play a mediating role for native/foreign distributional conflict, influencing electoral outcomes. They test this hypothesis by means of an analysis of public housing in Austrian municipalities and Viennese wards and find that "wards with at least $60 \%$ of adults in public housing increased their support for anti-immigrant parties by 5.0 percentage points" (Cavaille and Ferwerda 2018, 23) following the implementation of the EU directive that obliged Austrian municipalities to open public housing to immigrants. In their analysis, they also offer a disaggregated approach showing that the effect is stronger when it comes in the form of inkind transfers (such as the access to public housing) than when it is in-cash (e.g. rent subsidies). The authors also relate their results to austerity policy that did not adjust the supply of public housing to the dimensions of the new audience, thus exacerbating the distributional conflict. Ferguson et al. (2020), while not directly assessing austerity, offer an interesting insight on the role of public investments: in their assessment of the 2016 US presidential election, they find that the percentage of structurally deficient bridges at the congressional district level was a significant predictor of an increase in GOP votes in 2016 from 2012. As they argue, structurally deficient bridges are "a subtle but powerful indicator of the inability or unwillingness of state or local governments to fund infrastructure repairs. 
Such fiscally starved districts tended to shift votes toward Trump" (Ferguson et al. 2020, 115).

Austerity measures are clearly cited as reasons behind the victory of the "Leave" in the Brexit Referendum of 2016. Indeed, while "Brexit" cannot be reduced to the triumph of a populist movement, the referendum was strongly supported by the main British right-wing populist party, the UKIP, and prominent populist spokespersons. (Eatwell and Goodwin 2018) report it as an example of 'national populism.' As with the cases we have already discussed of populist parties, the roots of the 'Leave' at the 2016 British referendum appear to be in globalization and austerity policy. The key evidence in support of this idea was provided by Fetzer (2018) who argued that an area's level of exposure to fiscal consolidation has a causal effect on the local share of votes obtained by UKIP, which is in turn a major explanation of the local share of "Leave" votes at the Brexit referendum. The author concludes that the Referendum "could have resulted in a victory for Remain, had it not been for austerity" (Fetzer 2019). He then goes on to show that cuts to different types of social services were linked to different degrees of increase in UKIP scores. This choice resonates with both Vland and Halikiopoulou (2016) and Cavaille and Ferwerda (2018) and offers an important addition to our reasoning: in analyzing the moderating role of any type of welfare policy (in our case, local welfare), it is important to disaggregate it into different channels, either based on the form (in-kind/in-cash) or the scope (e.g. education, public housing etc.) to identify possibly different subchannels.

\subsection{Explaining the crisis of the Italian political system: economic observational} studies

Looking at the Italian case following the previous discussion, and in light of the long history of populist and radical right parties that have characterized Italy (Tarchi 2008), one would expect a large literature analyzing the Italian case through the lens of political economy. But research on Italian populism, and in particular on the economic roots of its success, is actually limited. To our knowledge, only one published article and two working papers address the role of economic policy in shaping the current Italian political system. The first one by Caselli et al. (2020) focuses on trade. Similar to Colantone and Stanig (2018), they find import competition from China to have contributed to the electoral outcomes of right-wing populist parties and the overall effect appears to work through the mediation of local labor markets. However, their analysis ends before the Great Recession, as they cover the 19942008 period, and consider only globalization as driving factor.

While trade integration is a major, and interesting, phenomenon, we consider that it represents only part of the explanation: indeed, one might argue that the problem rather than lying in the role of trade, lies in the lack of a large enough welfare state able to redistribute the gains of trade integration. We already know from studies such as Vlandas and Halikiopoulou (2016) or Fetzer (2018) that economic institutions can act as important moderators. The second study on the Italian case goes in this direction. Albanese, Barone, and De Blasio (2019) analyze the effect of EU funds on populist votes in Italy at 2013 national elections. They adopt a parametric spatial regression discontinuity design at the municipality level and focus on municipalities at the border between regions belonging to 
the Convergence Objective (that received on average more money) and other regions (that received on average less money). Their results show that municipalities that had access to more EU funds exhibit a statistically significant decrease in the vote share of populist parties. They also show that EU transfers are significantly and negatively related to populist votes regardless of their form, as there is no difference between investment and consumptionoriented funds. Once more, these results indicate the importance of differences in local redistribution policies to explain the geographical variation of electoral results. However, the authors did not include local welfare in their analysis and focused on EU funds only. Finally, Bloise, Chironi, and Pianta (2019) analyze how the regional economic structure relates to voters' turnout and votes shares of mainstream parties, the League, and the M5S in the 19942018 period. They find that where the League did well, territories experienced a downward pressure on the income of the middle classes and household wealth, while M5S did better in the poorest zones of the country, characterized by higher levels of precarious employment (if not straight unemployment) for the youth.

To summarize, the literature on the rise of populist parties appears to be divided on the actual role of the economy, as different authors emphasize a 'cultural backlash' rather than the reaction of the economic losers. Observational analyzes support an economic reading of the phenomenon: globalization, mostly via trade shocks, seems to play a role in explaining the geographical distribution of these parties. Moreover, the rise of populist parties also appears to be moderated by the national/subnational economic structure either in terms of institutions (Vlandas and Halikiopoulou 2016), inequality (Eichengreen 2018, Pastor and Veronesi 2018), and government spending austerity (Fetzer 2018; Albanese Barone, and De Blasio 2019). Survey experiments, on the other hand, seem to point towards cultural rather than economic grievances as main drivers. Rodrik (2020) and, empirically, Guiso et al. (2020), however, argue that there is only an apparent contradiction between these results. Indeed, one's position on non-economic issues or the salience of the issues in determining a voting preference might well be determined by the economic environment in which the individual lives.

\subsection{Hypotheses: the moderating role of local welfare in a changing political system}

We can now formulate the hypotheses that we want to test in the paper. Our reasoning is as follows: from previous research we know that economic explanations do offer an important element in understanding the changes that Western political systems have been experiencing in the last decades. In the Italian case we already know that trade exposure offers part of the answer (Caselli et al. 2018) and we therefore decide to investigate the "welfare channel", where redistribution acts as a moderator for the different distributional conflicts generated by globalization and the economic crisis. The "welfare channel" might be in play in the Italian case as well.

It is rather straightforward to note that the rise of populist parties and the crisis of the Italian center-left follows at least chronologically the adoption of national measures of austerity of various kinds. As we focus on a single country, however, we cannot really use national data to test the hypothesis of welfare as a moderator for the electoral success of populist parties/electoral decrease of center-left forces. In contrast to what Fetzer (2018) was able to 
do for the UK, we lack estimates of the local cost of austerity measures that could be used. We therefore decide to go down in the hierarchy and focus on local welfare. In line with the "welfare channel" hypothesis, local budgets might have acted to cushion the national shock.

But what exactly do we mean by local? We refer to the area in which a voter likely spends most of her time and has most of her immediate, social connections. Italy, as we will discuss in the next section, offers a specific statistical unit built around these interactions that allows us to take account of what Colantone and Stanig (2018) identified as the sociotropical behavior of voters. If the amount of local public services in the zone where a voter lives her everyday life affects her voting choices, than we would expect that areas where municipalities had higher post-austerity levels of per-capita expenditures would have better absorbed the national shock, thus increasing the voting percentages for center-left parties and decreasing those for populist parties. Following the literature, we also know that this effect might vary depending on the type of public service that is actually being financed, and we distinguish between social spending (or, in this paper, local welfare) and other spending. When data allows, we can also distinguish between what type of social service is financed, to have a more fine-grained analysis of the mechanism. Thus, as far as local welfare is concerned, our hypotheses are that, following the 2007-2009 economic crisis and the adoption of national austerity measures:

1a. Voting percentages for center-left parties have been higher in areas where per-capita local expenditures have been higher.

1b. Voting percentages for populist parties have been higher in areas where per-capita local expenditures have been lower.

2a. Voting percentages for center-left parties have been higher in areas where per-capita local social spending has been higher.

2b. Voting percentages for populist parties have been higher in areas where per-capita local social spending has been lower.

3. The relationships postulated in hypotheses $1 a-1 b$ and $2 a-2 b$ vary depending on the type of welfare expenditures.

In section 3 we also highlighted the importance, at least at the theoretical level, of inequality (Eichengreen 2018, Pastor and Veronesi 2018) as a predictor in the rise of populist parties. Indeed, we do already know from Bloise and Chironi that inequality is a predictor for M5S and League scores at a regional level. However, Italian regions can be as large as some European countries (e.g. Lombardy) and, while the observations are interesting, they do not say much about the day-to-day economic context in which most voters live. Here, we focus on local inequality and ask ourselves whether a more equal local context might have acted as a moderator for the rise of populist parties and the decline of the center-left. As such, we argue that, following the 2007-2009 economic crisis and the adoption of national austerity measures: 
4a. Voting percentages for center-left parties have been higher in areas where local inequality has been lower.

4b. Voting percentages for populist parties have been higher in areas where per-capita local inequality has been higher.

Finally, we turn our attention to the individual level mechanisms explaining voters' choices. We argue that the effects of the local economic environment act through individual-level values on different topics. From the literature surveyed in section 3, we know that there is a debate on the current relevance of economic issues as individual determinants. As part of the literature seems to argue that attitudes on non-economic issues, rather than economic ones, are the main drivers of populist voting we test this hypothesis. But, following Guiso et al. (2020), we argue that an individual's position on non-economic issues might be determined by the economic environment in which he or she resides.

5a. A voter's position on the economic dimension significantly predicts a person's voting preference.

5b. The current level of local expenditures and their variations compared to before the economic crisis are a significant predictor of an individual's position on both economic and non-economic dimensions.

Having stated our main hypotheses, we now turn our attention to the main characteristics of the Italian economy during the 2006-2018 period. In the following section, we discuss the different types of austerity adopted at the national level before outlining the evolution of local government spending in Italy and the main functions of local welfare.

\section{Crisis, Austerity, and the role of local government in Italy}

In order to understand how local welfare might have acted as a moderator for the political consequences of national austerity, thus lessening the crisis of center-left parties or the rise of populist parties in certain areas of the country, we first summarize what happened to the Italian economy before and after the Great Recession. We then look at how austerity operated in subnational spending in Italy at various levels.

\subsection{Italian austerity: a not-so-new story that accelerated following 2011}

The history of Italian economic stagnation is open to debate and starts well before the 20082009 economic crisis. As Storm (2019) shows, much of the economic slowdown that Italy has been experiencing is rooted in policies that actually were adopted some decades earlier, as Italian governments of different political leanings sought to transform the Belpaese into the Eurozone's poster child, shifting blame to the EU and external constraints for decisions taken in Rome rather than in Brussels. Italy in fact ran a budget surplus in each year following the signature of the Maastricht Treaty, with the exception of 2009 budget. This was the combined result of lower interest rates, a positive effect of the increased economic integration at the European level (Saraceno 2020), and the containment of public expenditures. Despite being the country with longest streak of primary surpluses among the five biggest countries 
in the EU, Italian public debt kept growing. As such, when the economic crisis started in 2007, Italy's public debt to GDP ratio was the highest in the EU according to Eurostat data. After an initial relative loosening of government expenditures, which led to a primary deficit in $2009^{10}$, Italian governments reacted to the crisis with new forms of fiscal consolidation that led to a sharp decrease in public expenditures compared to 2009 peak: as the GDP was falling, so was government spending, with the aim of keeping public debt under control. This was particularly true after 2011, as a consequence of the rise to power of a technocratic cabinet led by Mario Monti, supported by the main parties of the left and of the right. Cuts were particularly concentrated on social protection: according to Pavolini et al. (2015), after 2009 social expenditures decreased by $0.9 \%$, compared to a decrease of $0.6 \%$ at the EU level. As such, while in 2008 per-capita expenditures on social protection were at $80 \%$ of the EU4 average, they were just $72 \%$ of the EU-4 average in 2018 (Storm 2019). As the crisis hit, austerity thus actually accelerated.

The decrease in government spending, in particular on social spending, did not happen only through cuts; even sectors that experienced a nominal growth actually saw their budgets decrease in real terms as often planned increases came in at paces lower than inflation. According to the Italian think tank GIMBE (2019), this is what happened to the Italian national health service, which faces an aging population with increasingly fewer resources. According to GIMBE's report, public funding was cut by over $€ 37$ billion, of which about 25 billion happened in 2010-2015 due to cuts resulting from various financial measures and over 12 billion in 2015-2019, when fewer resources were allocated to healthcare than those required and initially planned. In absolute terms, public financing increased by 8.8 billion in 10 years, growing on average by $0.9 \%$ per year, a rate lower than that of average annual inflation $(1.07 \%)$.

Austerity measures were not limited to government current spending. Two important reforms profoundly modified the labor market. First, there was the 2011 pension reform that had both implications for the labor market and for future spending. Supported by a large alliance of parties in Parliament, while the only major parties speaking against it were 'populist' parties such as the League and the Five Star Movement ${ }^{11}$, the reform sped up the already planned transition of the Italian pension system towards a fully implemented 'notional defined contributions' model, by raising contribution rates for the self-employed whose scheme was historically less expensive the employees' one. The most controversial part of the reform, however, concerned the increase of retirement age to 66 years and 7 months coupled with the introduction of an automatic alignment of retirement to life expectancy. Following the reform: "the Italian pension system has adopted one of the least 'generous' institutional frameworks in Europe, if looking at forecasts for the expenditure level in the years to come." (Pavolini et al. 2015, p.4).

\footnotetext{
${ }^{10}$ It should be noticed that the Italian primary deficit at $-0.8 \%$ was still lower than the French one $(-4.6 \%)$ or the Euro-4 one $(-2.4 \%)$, thus indicating a more restrictive policy than that of their neighbors.

${ }^{11}$ Although lacking a parliamentary representation at the time.
} 
As national labor markets and social security both experienced profound changes following the 2011-2012 economic reforms led by Monti's cabinet, local authorities saw important decreases in their funding.

\subsection{Local welfare in times of austerity}

According to Bolgherini (2014), local authorities were "among the main victims of the global financial crisis." Indeed, the economic crisis led many European countries to revise their policy of decentralization or even to put an end to it. Often in an attempt to shift the blame (Kennett et al. 2015), central governments pushed down austerity measures via cuts to the budgets of local authorities (Kim and Warner 2020; Ferry, Ahrens, and Khalifa 2019; Gray and Barford 2018; Morris et al. 2017), a form of 'scalar dumping' (2014) also often coupled with privatizations and liberalization of local services. Italy was no exception (Di Feliciantonio 2016; Pollio 2016) and, here again, we can see a trend that started before the economic crisis and accelerated afterwards. The first signs of a revision of the decentralization process actually started as early as 2007, when the national budget law heavily reduced the number of already existing municipal agencies and hindered municipalities from setting up new ones. This law was quickly followed by a series of small reforms that, among other things, greatly reduced the number of municipal representatives and abolished the role of municipal ombudsman. However, pre-2009 reforms were clearly focused on the administration; while reforming the administration might have spill-overs on the provision of local public services, these were not targeted per se.

Data show that public employees were among the first casualties of this strategy. According to Bolgherini (2014), the total number of public employees in local functions decreased by $6.15 \%$ in 3 years between $2010-2013$, with particularly harsh cuts to temporary employment, which decreased by $24.6 \%$. The situation did not improve after the (alleged) end of the Great Recession. A report by the Italian Ministry of Finance (MEF 2019) shows local government lost $13.7 \%$ of its workforce between 2009 and 2018, diminishing the number of active public employees in local functions by around 81,000 people. As such, the number of civil servants in local governments per 1,000 inhabitants decreased from 9.8 in 2009 to 8.5 in 2018.

After the crisis, however, cuts were applied directly to transfers from the central government to local authorities which then had to make choices as to which services to prioritize. As we can see in Table 2, all branches of local government experienced a decrease in their percapita spending in real terms between 2008 and $2017^{12}$.

122017 is the latest year for which the Italian national bureau of statistics (ISTAT) offers aggregate data for all branches. 


\begin{tabular}{lllll} 
LOCAL AUTHORITY & $\begin{array}{l}\text { 2008 PER CAPITA } \\
\text { CURRENT } \\
\text { SPENDING IN } \\
\text { 2010€ }\end{array}$ & $\begin{array}{l}\text { 2018 PER- } \\
\text { CAPITA } \\
\text { CURRENT } \\
\text { SPENDING } \\
\text { IN 2010€ }\end{array}$ & DIFFERENCE & $\begin{array}{l}\text { \% } \\
\text { VAR. }\end{array}$ \\
\hline REGIONS & $2,765.76 €$ & $2.566 .78 €$ & $-198.97 €$ & $-7.2 \%$ \\
$\begin{array}{l}\text { PROVINCES AND } \\
\text { MUNICIPAL UNIONS }\end{array}$ & $168.28 €$ & $125.32 €$ & $-42.96 €$ & $-25.5 \%$ \\
MUNICIPALITIES & $852.92 €$ & $843.24 €$ & $-9.67 €$ & $-1.1 \%$
\end{tabular}

Table 2. Evolution of local current expenditures by local authority 2008-2018. Source: MEF 2019.

In this context, we decided to focus on municipal-level expenditures to assess the role of local welfare as a moderator. Municipal budgets are more important than those of provinces and represent a better approximation of voters' areas of living than regions. As we are not investigating the effects of local austerity, but the effect of local welfare as a mediator for national austerity the fact that municipalities were hit less hard than regions and provinces does not have serious consequences for our reasoning. Finally, the myriad Italian municipalities and the possibility of re-aggregating them in socially connected territories offers us a better base to econometrically test our hypotheses.

\section{Data selection and methodology}

In the following paragraphs, we present the main sources of our data, discuss how we decided to re-aggregate municipal data to have a better representation of the territory where an elector actually lives, and illustrate the methodology used to test our hypotheses.

\subsection{Municipal budgets and local inequality}

In order to test hypotheses $1-3$, we collected budgetary data over the $2005-2018^{13}$ period for over 8.000 Italian municipalities. ${ }^{14} \mathrm{We}$ then took into account the different mergers to obtain a longitudinal dataset based on the municipalities of the latest election included in this paper, the 2019 European election, for a grand total of 7914 municipalities. The data was collected by using a web-scraping script in $\mathrm{R}$ and was extracted from the webpage of the 'Direzione Centrale per la Finanza Locale', the branch of the Ministry of the Interior in charge of local finance. Italian municipalities need to compile every year two reports, called 'certificati', one outlining the budget of the previous year ('certificato consuntivo') and the other with the estimates for the current year ('certificato preventivo'). To have more reliable data, we decided to rely on the former as it reports the actual spending during the year. It should be

\footnotetext{
${ }^{13}$ As we will explain later in the text, budgetary data is lagged one year with respect to election data; thus while the analysis of political data is from 2006 to 2019, balance sheets cover the 2005-2019 period.

${ }^{14}$ The number has been steadily declining because of merging and fusions.
} 
noted that the report is not unique across years; following a reform in 2015, the report changed to its current version, the so-called 'harmonized accounting' ('contabilità armonizzata'). This did not change the aggregate values, though; because the first year municipalities had to compile both the old and the 'harmonized' version, we were able to check consistency between the aggregate values of the two reports. As such, comparing aggregate expenditures across time does not lead to biases related to the changed bureaucratic procedure. However, it should be noted that data on local budgets were not always available for all municipalities due to delays and/or errors in the transmission of the information. Nevertheless, as we see in Figure 2, missing values account only for a small fraction of the total population and in the least complete year, 2018, municipalities for which data is available accounted for $97.4 \%$ of the Italian population.
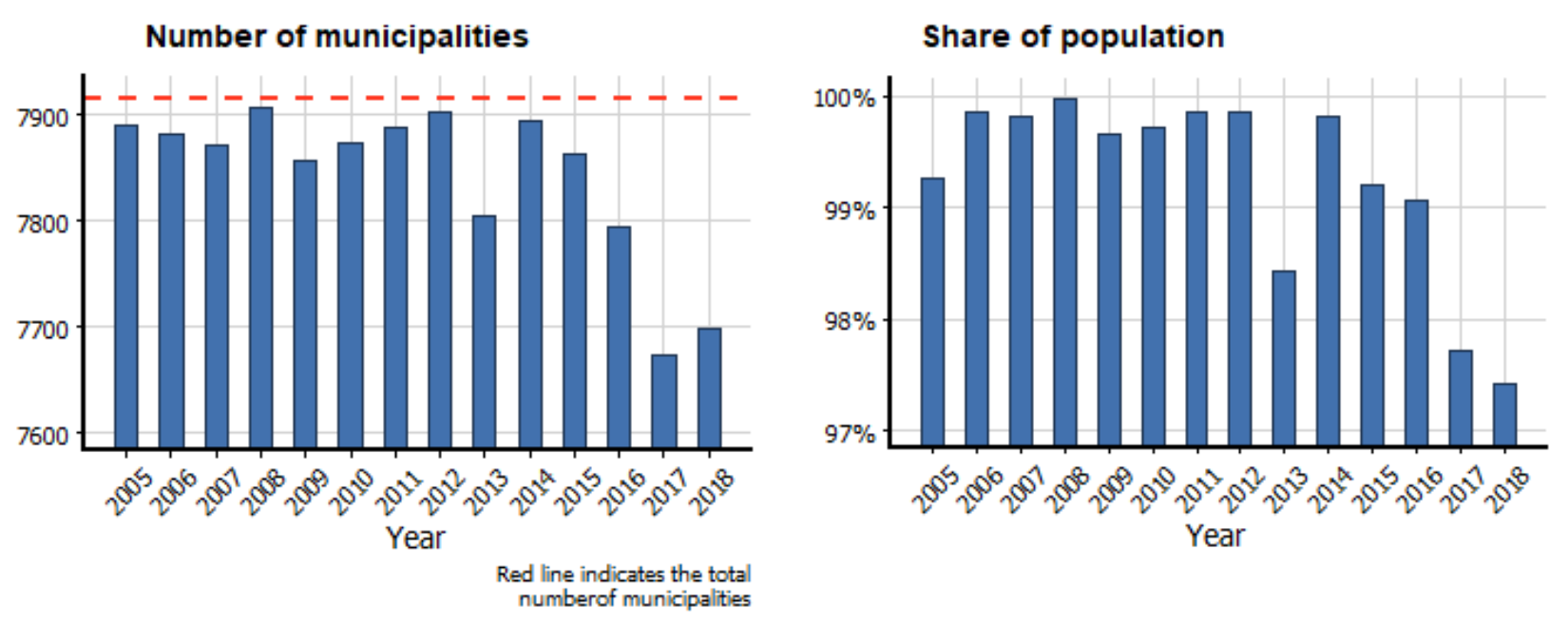

Figure 2. Number of municipal budgets and share of population by year.

Each year, Italian municipalities report three different kinds of expenditures in their balance sheet, reflecting a difference between accrual basis and cash basis: commitments ("impegni"), payments ("pagamenti in conto competenza"), and arrears ("residui"). We decided to use the sum of payments and arrears as this value reports only those payments that have effectively been made (Ferraresi et al. 2016). Finally, we decided to focus on current expenditures rather than considering all other forms of spending (like capital spending or loan reimbursement) since we expect voters to react more quickly to the financing of day-to-day public services than to long-term investments.

$\mathrm{H} 2 \mathrm{a}, \mathrm{H} 2 \mathrm{~b}$ and $\mathrm{H} 3$ focus on the function that is financed, rather than on the aggregate level of expenditures. We argue that local social spending after the economic crises might have become a significant predictor for the share of populist parties as well as center-left parties. Since Italian municipalities have little-to-no say on labor market policy, we focus on what Foster and Frieden (2019) call expenditures on services, most notably education and public transportation (which includes subsidies for local mobility to low-income people and students). While the 2015 reform did not modify the reporting of total aggregates, the same does not apply to data on disaggregated spending as the number of functions and the way spending is assigned to a certain function changed after 2015. We therefore proceeded to merge the different functions (which in the balance sheet go under the name of 'missions') 
and we distinguish between two main categories: social spending on the one hand and other spending (see Appendix). This new aggregation produces fairly good results as the differences between reporting in the harmonized version and in the old version are limited (social spending in the harmonized balance sheet is $0.5 \%$ higher than in the pre-2015 version).

$\mathrm{H} 4 \mathrm{a}$ and $\mathrm{H} 4 \mathrm{~b}$ shift attention to the moderating role of local inequality. We test these hypotheses by calculating a local Gini coefficient relying on municipal level data on individual taxable income obtained from the Ministry of Finance. Unfortunately, such data is available only since 2008, thus limiting the temporal width of our analysis for these hypotheses.

\subsection{The 'Sistemi Locali del Lavoro'}

As argued in the introduction, we are interested assessing the role of the local economy. Often, by "local" authors mean the lowest possible administrative unit: in our case, municipalities. We decided to adopt a different approach, as often people live their lives across different municipalities, and reaggregated our data into somewhat higher units that would better catch these interactions. Luckily for us we did not have to build it on our own. Italy offers three main statistical subunits to reaggregate municipalities: departments ("province'), electoral constituencies ("college" or "circoscrizioni" depending on the elections), and labor market areas ("Sistemi Locali del Lavoro" - SLLs from now on). As the Italian electoral system has been changing across the years, electoral constituencies changed too and thus could not provide a valid way to reaggregate municipalities. By contrast, both departments and SLLs are stable in number and borders across the years. ${ }^{15}$ Using municipal data it is thus possible to reaggregate municipalities in a consistent way.

However, two main elements led us to choose the SLLs. First, SLLs are statistical units identified not on administrative grounds, but based on the extent of relationships that the inhabitants of a certain area have with each other. As the Italian Bureau of Statistics (ISTAT) explains, SLLs are geographical areas "where the population lives and works and where it therefore indirectly tends to exercise most of its social and economic relations" (ISTAT 2015, 1). SLLs are identified as the areas "that maximize the level of interaction between municipalities belonging to the same SLL, expressed by the daily commuting flows' (ISTAT 2015) and tend share a similar economic structure. The second difference between departments and SLLs is represented by their number: Italy counts a total of 610 SLLs in June 2019 while departments are only 107. As such, the use of SLLs appears to be a better fit for our research: first, the larger number of units allows for better statistical modeling and, second, the way SLLs are constructed offers more solid ground for the interpretation of our results as they are identified specifically based on the interactions between the inhabitants of a certain areas using commuting as a proxy.

\footnotetext{
15 The number of departments has been changing in the 2005-2019 period, but changes concerned a limited number of departments and it would have been possible to reaggregate municipalities based on current boundaries.
} 
A contributing factor in our decision to reaggregate municipalities was the fact that some socio-economic data is not available at the municipal level for non-census years. From previous literature we know that different covariates, in particular unemployment, predict the share of votes for populist parties at both department and constituency levels (Levi and Patriarca 2020). However, data on unemployment is not available on a year-by-year basis for all municipalities as that is collected only every 10 years. As such, while municipalities could still be a good level of analysis on theoretical ground to test our idea of local welfare, they would not be the proper level of analysis from a statistical point of view as we would not be able to control for unemployment in non-census years. As such, we decided that SLLs offered us the better solution.

While the choice of SLLs does solve a major problem (the lack of up-to-date data on unemployment, a large enough number of observations, and an area designed on people's interactions), it also led to new ones. In particular, missing municipalities were not always the same for each year. This might be problematic when one relies on aggregated data and individual fixed effects since the 'individual' in one year is no longer the same in the following year. As such, for each year, we decided to keep only those SLLs whose reporting municipalities represent at least $80 \%$ of the SLL population. This slightly decreases the representativeness of our sample as it now accounts for $95.3 \%$ of the Italian population (see Figure 2) in the least complete year (2018). ${ }^{16}$
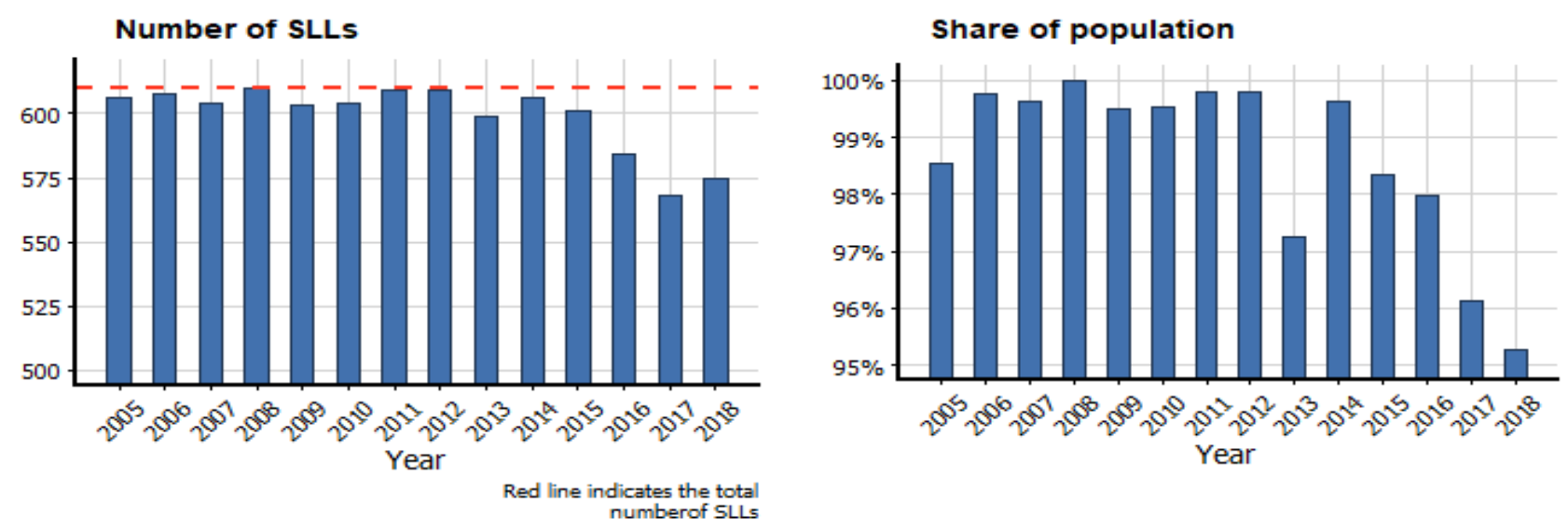

Figure 3. Number of SLLs with municipalities reporting budgets for at least $80 \%$ of the population and share of population living in reporting municipalities in considered SLLs by year.

Spending data is then divided by the population of the non-missing municipalities to obtain nominal per-capita values. Finally, we use GDP deflators as calculated by the Bank of Italy to obtain real per-capita expenditures.

Figures 4 and 5 show the evolution of average per-capita municipal expenditures by year, as well as the evolution of social spending. Consistent with what we discussed in section 4 , our

${ }^{16}$ As a robustness check, we ran the same models using only those SLLs able to pass the $80 \%$ threshold every year. The results for models 1-3 are not statistically different. 
sample shows a clear decrease compared to pre-crisis periods and especially following the 2011 change of government and the arrival of Mario Monti as Prime Minister (Fig. 5 and 6). Finally, to test our hypotheses 3, we proceeded to regroup by function and to distinguish between the following categories: education and family; law and order; industry, tourism, and agriculture; city planning and housing; environment and garbage disposal; transports; other spending. Table 1 in the appendix shows our categorization of each budgetary heading, while Table 2 in the appendix reports the descriptive statistics of our main independent variables.

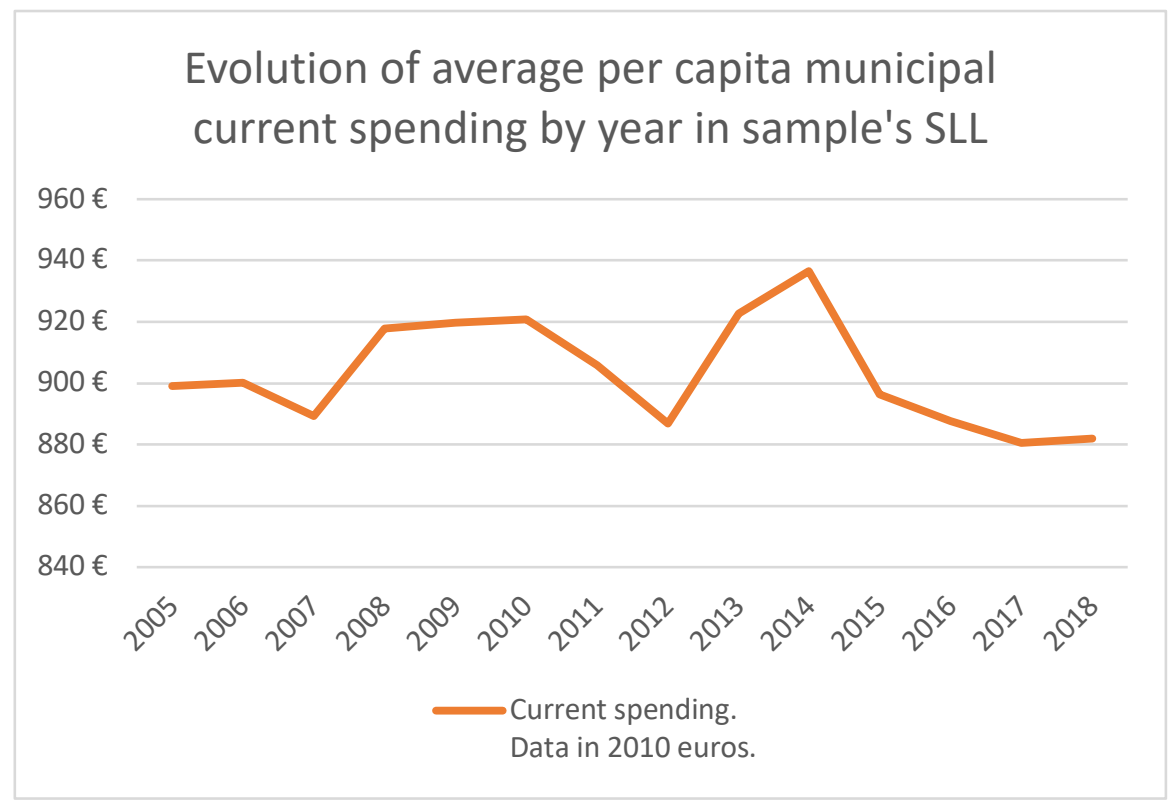

Figure 4. Evolution of per-capita local current spending in sample's SLL. Data expressed in $2010 €$.

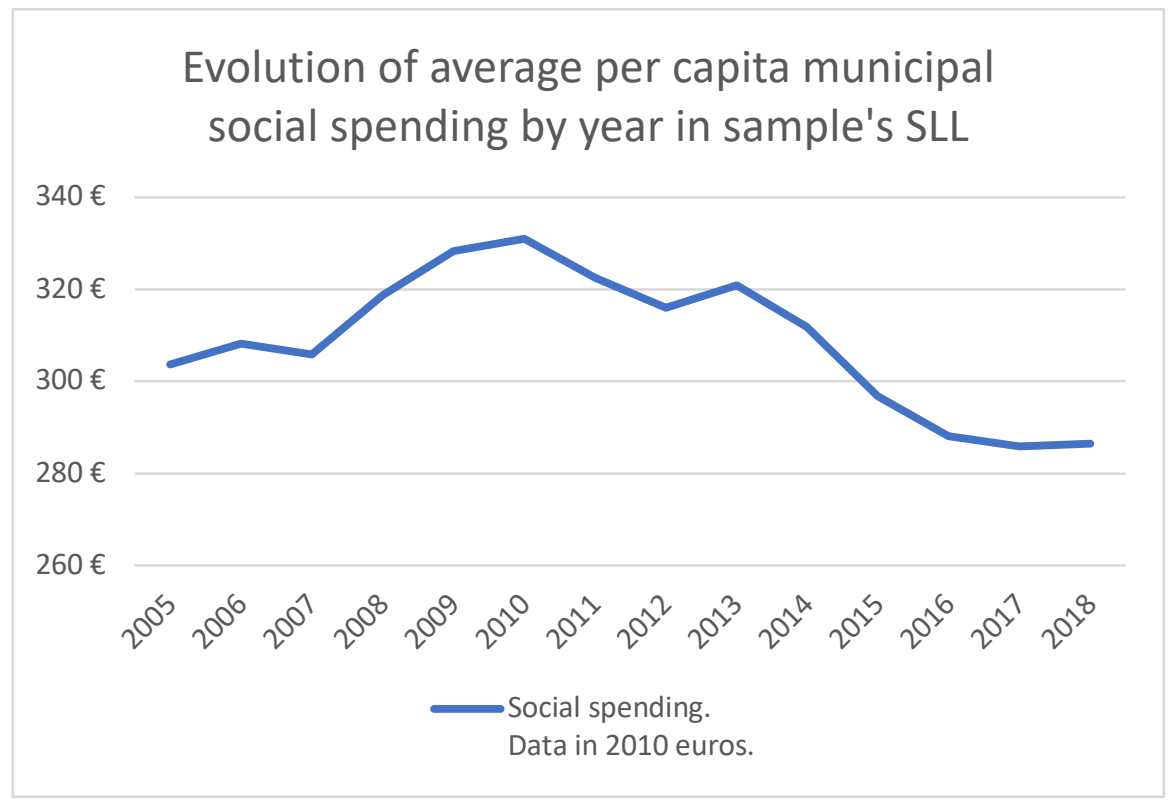

Figure 5. Evolution of per-capita local social spending in sample's SLL. Data expressed in $2010 €$. 


\subsection{Electoral data}

Voting percentages for center-left and populist parties represent the main dependent variables of our study. We collected municipal-level data for all national elections between 2006 and 2019 using the Archivio Storico delle Elezioni of the Italian Ministry of the Interior. In total, our dataset includes four Parliamentary elections (2006, 2008, 2013 and 2018) ${ }^{17}$ and three European elections $(2009,2014,2019) .{ }^{18}$ Results were then re-aggregated to the SLL level. In order to deal with the presence of missing values in the municipal-level data for local budgets, for each election at time $t$ we included only non-missing municipalities at $t-1$. We opted for this solution for two reasons: 1) we expect economic policy to have a lagged impact on political behavior and 2) all elections took place in the first half of the year, thus being temporarily close to the year that just ended.

Having constructed the dataset, we faced a non-trivial choice: as our hypotheses refer to center-left and populist parties, we needed to classify political forces. The choice is nontrivial because the Italian party system is unstable and political parties come and go at an impressive rate. We decided to construct four variables to be the dependent variable for hypotheses 1 to $4: 1$ ) vote shares as a percentage of valid votes for the center-left; 2) vote shares for the League; 3 ) vote shares for populist parties of the right, namely the League and FdI; 4) vote shares for populist parties in general, so those of 3) plus the M5S. We rely on total valid votes as the denominator, thus ignoring the possible effects of differential turnout. As far as the center-left is concerned, the main problem appeared to be the difference between the moderate and the radical left. We decided to look at how stable a list was in its alliance to center-left forces. Thus, we included in our center-left category the PD and its pre-2008 ancestor, the Ulivo, as well as all minor forces allied to the PD in each election and splits such as the experiment of Liberi e Uguali in 2018. We excluded communist forces in 2006 as they would no longer be allies of the center-left in successive elections. ${ }^{19}$

As the second leg of our study concerns the rise of populist parties, we had to perform a similar classification for them. This requires care; populism in Italy is a multifaceted phenomenon (Caiani and Graziano 2016). While there is a clear consensus on the M5S (Ivaldi, Lanzone, and Woods 2017), the situation is less obvious for other parties. One could argue, with Verbeek and Zaslove (2015), that populism has been an integral component of the Italian center-right since its founding with the arrival of Silvio Berlusconi's Forza Italia in 1994. Indeed, the "PopuList" (Rooduijn et al. 2019), one of the main sources for the study

\footnotetext{
${ }^{17}$ It should be noted that the Italian Parliament is divided in two branches and the Italian electorate is called to renew both of them together: a lower chamber (Camera dei Deputati - Chamber of Deputies) and a higher chamber (Senato della Repubblica - Senate). The electorate for the two is not the same as the voting age is higher for the Senate than for the Chamber. As such we included only data for the latter that has a larger electoral body.

${ }^{18}$ Despite a reform that took place in 2018 adding a share of single-member districts and replacing the national majority premium of the previous election, the 2006-2018 election law was still mainly a PR system. Indeed, as shown by Cavallaro, Pregliasco and Vassalo (2018), the role of candidates in single member districts was limited, thus allowing us to include 2018 in our sample.

${ }^{19}$ As a robustness check we re-ran our tests including communist parties. Nothing substantially changes in the results in terms of significance, direction or magnitude of the effect.
} 
of populism, includes under "populism" all main center-right forces. Forza Italia, its shortlived evolution, the Popolo delle Libertà, the League, and another party, Fratelli d'Italia (Brothers of Italy - FdI from now on), are all considered populist parties. However, in our opinion, it would be a mistake to mix Berlusconi's party with the League and FdI. Although always allied, the latter forces are clearly populist radical right parties, characterized by strong nativism, authoritarianism, and populism (Mudde 2007). Forza Italia positions on the three dimensions are vaguer. According to Caiani and Graziano (2016), even in regard to populism much of the discussion depends on whether one considers style and organization (on which Berlusconi's party appears as a populist party) or ideology (on which, instead, debate is more open and varies from election to election). Moreover, in many regards Berlusconi's choices during the economic crisis put his party on the opposite side of populist forces: first he supported Monti's cabinet between 2011 and 2013 and he then forged a postelectoral parliamentary alliance with the center-left in 2013 leading to a Grosse Koalitione government. Given its debatable status we did not include Forza Italia in our analysis, which focuses on populist radical right parties such as the League and FdI. We do so by considering both the electoral dynamics of the League alone, as the party was able to go from $4 \%$ in 2006 to $33 \%$ in 2019 , and then together with FdI, as a populist radical right pole.

The fourth party of interest to our study is the M5S. As previously argued, there is little controversy about the populist nature of the M5S (Ivaldi, Lanzone, and Woods 2017) and its suitability for inclusion in the study is not really disputed. What represents a problem is the timing. In our hypothesis, local welfare represented a cushion capable of absorbing the effect of national austerity measures. However, the M5S did not participate to any national election before 2013, so it appeared already after the adoption of national austerity measures. Our identification strategy (see the section 6) clearly distinguishes between a pre- and a postausterity period, thus limiting out ability to test our hypothesis on the M5S alone. Therefore, we turn our attention to populist parties in general and we add M5S scores to those of the League and FdI.

Given the peculiarities, both in terms of electoral law and party system, of the two multilingual regions, the French-speaking Valle d'Aosta and the German-speaking Trentino - Alto Adige, SLLs from both regions are excluded from our analysis.

Table 2 in the appendix reports the main descriptive statistics for our dependent variables: center-left parties, the League, populist parties of the right, and all populist parties between 2006 and 2019. For a list of all political parties and their categorization, see table 2 in the Appendix.

\subsection{Socio-demographic data}

In our tests we include socio-demographic controls. In particular, we rely on public data by the ISTAT on-line data-warehouse to obtain, at the SLL level, (1) the share of elderly population aged 65 or more; (2) the share of foreign born population; (3) population density expressed as inhabitants per squared kilometer; (4) the unemployment rate; and (5) the share of residents with a tertiary college degree. Refer to table 2 in the appendix for the descriptive statistics for our control variables. 


\subsection{Explaining the mechanism: the voting advice application survey}

Our H4 states that we expect local expenditures to influence how voters position themselves on economic and non-economic issues. In order to investigate this hypothesis, we rely on data collected using a voting survey instrument (or Voting Advice Application [VAA])called 'TrovaPartito' taken between May 12 ${ }^{\text {th }}$ and May 25 ${ }^{\text {th }}$, 2019, just before the 2019 Italian European Election.

The survey was divided in two parts: in the first part, respondents were asked their degree of agreement on a scale from 1 (complete disagreement) to 5 (complete agreement) on 28 items corresponding to different themes of discussion during the last year. The items were selected to be as close as possible in the wording to already existing questions from international surveys already fielded in Italy.

The second, optional, part of the VAA consisted of 9 additional items that would allow us to build the socio-demographic profile of the respondent. The VAA attracted many respondents and more than 300,000 people took part in the survey. Out of these, 69,722 left us enough information to build post-stratification weights. VAAs are becoming a more and more common tool to analyze politics (Garzia and Marschall 2016; Wheatley 2016). The literature underlines biases from the combined use of nonprobability sampling and web-only surveying together. The raw samples from TrovaPartito are indeed non-representative of the Italian population, favoring those who are more educated and younger, as one would expect from this type of research (Anderson et al. 2014). Moreover, different studies (Pianzola 2014; Pol et al. 2014)) found "systematic selection biases among VAA users, with the implication that VAA-generated data are not typically externally valid" (Sheppard 2018,3). As the discussion on the best way to treat VAA data is ongoing, two main suggestions seem sensible: (1) use post-stratification weighting on multiple variables with a known distribution to make the survey more representative; (2) rely on other probability samples to test the external validity of the sample distributions. Even in these cases, data from VAA would still need to be taken with a pinch of salt, since people participating in the survey do so for specific reasons that distance them from the general population. But depending on the object of the analysis this might not matter much as this would appear to be the case of political dimensionality according to Wheatley and Germann (2014). In line with other studies (Wurthmann et al. 2020), we prepared post-stratification weights to make the sample representative of the Italian population of age in terms of gender, age group, educational attainment, geographical distribution, and vote at 2018 general election. Weights were calculated using an iterative proportional fitting function in STATA (Bergmann 2011) with an upper threshold of 10 and lower threshold of 0.1 . To check the external validity of our results, we also included six of the 28 items in a CATI survey fielded between the 25/05/2019 and 26/05/2019 on a probability sample of 5,000 respondents. A comparison of the means and standard deviation of these items between the two samples shows minimal differences, although we would highlight that the VAA sample tends to prefer more "extreme" scores compared to the CATI sample, resulting in a higher standard deviation (See table 3 in the Appendix).

Finally, in order to test our hypotheses $5 \mathrm{a}-5 \mathrm{~b}$, we decided to regroup our items in 4 different dimensions that, we argue elsewhere (Cavallaro et al. 2018) structure political conflict in 
contemporary Italy. First, relying on 8 items, we identify an economic dimension of conflict that distinguishes between two poles: one of the "left"" that is more favorable to state intervention and workers' organization, and the other on the "right", more in favor to free markets. Our second dimension is built on what Hooghe and Marks (2018) call the "transnational" cleavage and contrasts people who favor greater European integration and have a positive view of immigration with those who hold negative judgments on immigration and oppose any further integration at the European level. The classic 'cultural' cleavage is at the core of our third dimension, which opposes progressive views on homosexuality, abortion, and security to more traditionalist stances. Finally, given the importance that the debate on elites seems to have in Italy (Bordignon, Ceccarini, and Diamanti 2018), we propose a 'populist' dimension. We included in the survey a group of four items on the relationship between the establishment and anti-establishments. (See table 4 in the appendix for more information about the items comprising each scale and descriptive statistics.) An individual score on each dimension is the average of the respondent's score on the $4 / 8$ items on which the scale is built. As such, each scale ranges from 1 to 5. We rely on Cronbach's Alpha to check the internal consistency of our constructs. We obtained measures above the validity threshold of 0.60 for the economic dimension, the transnational cleavage, and the cultural dimension. The threshold is not met by the establishment/anti-establishment dimension and, as such, we make limited use of these results.

While the survey included a question on where a respondent lived, it only asked for the provincia of residence as respondents would hardly be able to recognize the name of an SLL. This has some consequences on our hypothesis $5 \mathrm{~b}$ since we cannot aggregate expenditures and calculate local inequality at the same level of hypotheses 1-4. As such, we move up one level and obtain the average per-capita local spending and the local Gini coefficient at the provincial level following the same rules outlined in section 5.2.

\section{Methodology}

In order to test our hypotheses, we proceed in two stages. The first relies on observational data collected at the municipal level and re-aggregated at the SLL level. It focuses on the moderating effect of local welfare and inequality on the electoral results for the Italian centerleft and populist parties following the economic crisis and the adoption of austerity measures, as encapsulated in hypotheses 1-4. The second stage analyzes the mechanisms translating economic inputs into cultural attitudes. For this we rely on survey data and we test hypotheses $5 \mathrm{a}$ and $5 \mathrm{~b}$.

\subsection{The observational study}

As far as hypotheses 1 to 4 are concerned, the study relies on an approach similar to the one developed in Fetzer (2018) to test the effects of austerity on the votes for UKIP and in Bloise, Chironi, and Pianta (2019). In particular, we estimate the following pooled OLS regressions:

$y_{i, t}=\alpha_{i}+\theta_{t}+\beta_{1} \operatorname{Exp}_{i, t-1}+\Theta_{i, t}+\beta_{2} \mathrm{X} \mathbf{1}($ Year $>2011) \mathrm{X} \operatorname{Exp}_{i, t-1}+\rho \mathrm{X} \mathbf{1}($ Year $>$ 2011) $\mathrm{X} \Theta_{i, t}+\varepsilon_{i, t}$ 
$y_{i, t}=\alpha_{i}+\theta_{t}+\beta_{1} G I N I_{i, t-1}+\Theta_{i, t}+\beta_{2} \mathrm{X} \mathbf{1}($ Year $>2011) \mathrm{XINI}_{i, t-1}+$ $\rho \mathrm{X} 1$ (Year $>2011) \Theta_{i, t}+\varepsilon_{i, t}$

Our dependent variable $\mathrm{y}_{\mathrm{i}, \mathrm{t}}$ is the share of valid votes obtained by either the center-left, the League alone, populist parties of the right (League + Brothers of Italy) or all populist parties taken together (League + Brothers of Italy + M5S) in the SLL $i$ in year $t . \alpha_{i}$ is the SLL fixed effect used to account for any time-invariant characteristics at the SLL level, while $\theta_{i, t}$ is the regional year fixed effect at time $t$. Depending on the hypotheses that we are testing, our independent variable $\operatorname{Exp}_{i, t-1}$ is: 1a-1b)the amount of per-capita current municipal expenditures in the SLL $i$ in year $t-1 ; 2 \mathrm{a}-2 \mathrm{~b}$ ); the amount of per-capita current municipal expenditures on welfare in the SLL $i$ in year $t$ - 1 ; or 3 ) the amount of per-capita current municipal expenditures on different categories of services in the SLL $i$ in year $t$ - 1 . In equation (2), we replace the pro-capita municipal expenditures with an estimate of the Gini index, indicated by $G I N I_{i, t-1}$ in the equation, at the SLL level in order to test hypothesis 4 .

The dummy variable 1 (Year>2011) ${ }^{20}$ equals zero if the election was held before or in 2011 and 1 if the election was held after 2011, when austerity policies clearly accelerated under Monti's cabinet. This is our main independent variable. It tells us whether, after the economic crisis and the adoption of national measures of austerity, the center-left/the populist parties' scores, compared to before the economic crisis, were higher/lower in those areas where municipal spending was higher.

The last element of the equation, $\Theta_{i, t}$ is a vector of control variables that interacts with the austerity dummy in $\rho$ X 1 (Year $>2009$ ) X $\Theta_{i, t}$. The choice to interact all control variables seems to us justified since a variation in the relationship between the DV and some of the main controls (e.g. the share of people aged 65 or more) following 2009 might reflect itself in the interaction term between current expenditures and the austerity dummy. For example, let us assume that the center-left, compared to pre-2009, started obtaining better scores in SLL with a higher share of elderly population and that the share of elderly population has an impact on local expenditures (as is actually the case) leading to higher levels of municipal spending. In this case, the interaction term between the austerity dummy and per-capita local expenditures would also catch this relationship and, while significant, this might be because of a spurious correlation.

Since in our pooled regression we include together both Parliamentary and European elections, to verify the robustness of our results we re-run the model on Parliamentary elections only. Standard errors are clustered at SLL level. Finally, Figure 6 offers a visual summary of our regression strategy for hypotheses 1-4 in terms of path analysis.

${ }^{20}$ The equation does not include the base level for the 'austerity' dummy as, given the presence of year's fixed effects, it acts through the fixed effect. 


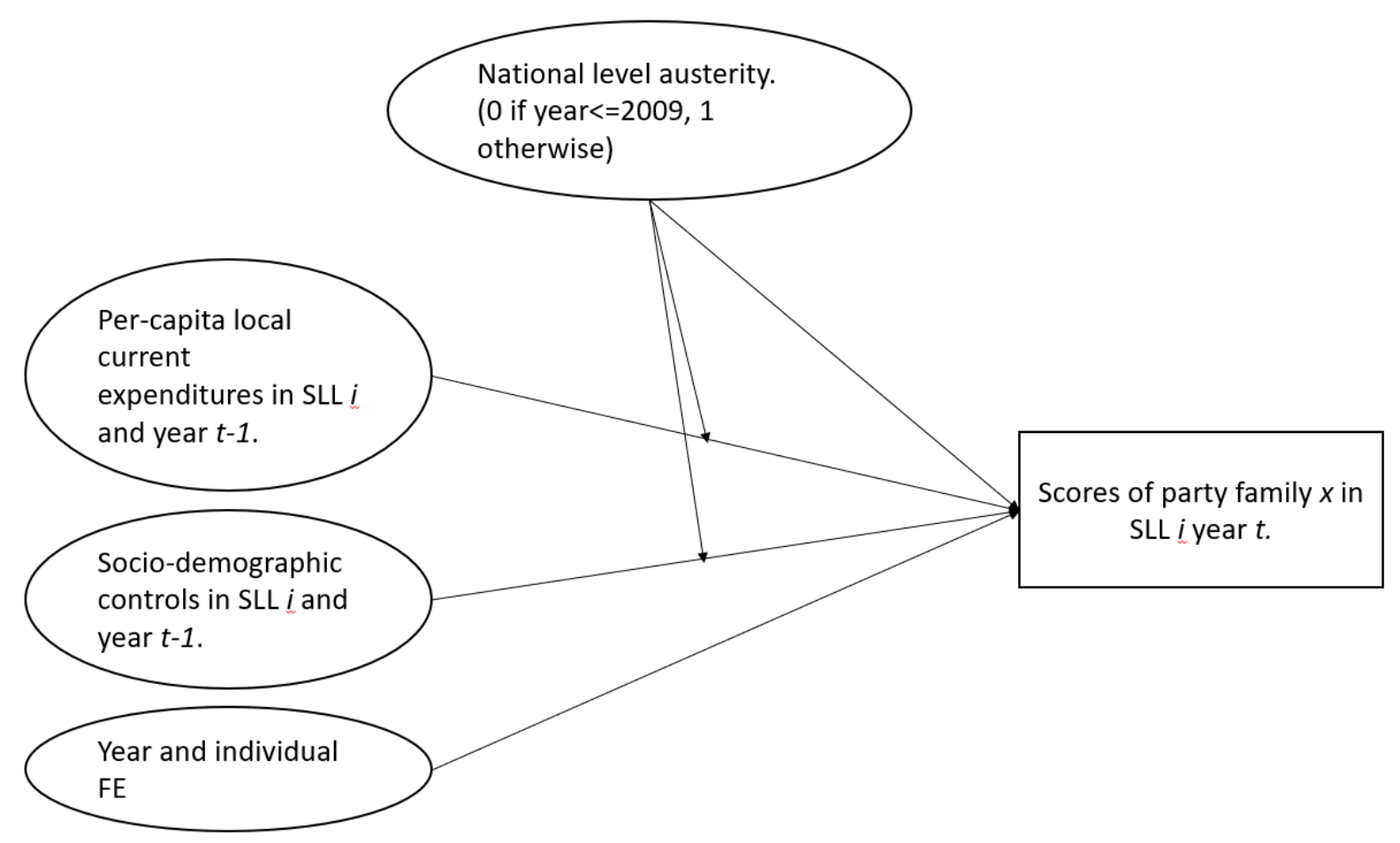

Fig. 6 - Path analysis diagram showing the moderating effect of per-capita local current expenditures on national austerity.

\section{Results for 6.1 The survey}

Our hypothesis 5a states that attitudes on so-called "cultural" issues better explain support for populist parties than attitudes on economic issues. In order to test this idea, we run a multinomial logistic regression to compare the relevance of economic and non-economic issues. Our dependent variable is one respondent's voting preference at 2019 European election and we distinguish between one of the four different center-left parties running in 2019, the League, FdI, the M5S, Forza Italia, and other parties. Our main independent variables are respondents' positions on the the four dimensions of conflict: economic, cultural, transnational, and the establishment/anti-establishment scale. In line with the relevant literature (Rydgren 2012), we also control for a respondent's age, gender, level of education, and geographical zone of residence.

Finally, in hypothesis $5 \mathrm{~b}$ we test whether one individual's position on different issues is influenced by the local economic environment in which he lives. As such, we run the following OLS regression:

$\mathrm{y}=\alpha+\beta_{1} \operatorname{Econ}_{p}+\Theta_{p}+\gamma+\varepsilon(3)$

where $y$ is a respondent's position on each of the four dimensions of conflict identified in the VAA survey; while Econ $_{p}$ is the independent variable of interest, namely either the percapita average municipal current expenditure in the respondent's province of residence or the level of inequality measured using the Gini coefficient in 2018. Since the survey was 
fielded only in one year, 2019, we decided to test as covariates not only per-capita expenditures and inequality in year 2018 but also the 2008-2018 differences. Each variable is tested in a separate model. Finally $\Theta_{p}$ represents a vector of control variables at the provincial level, namely the rate of unemployment, the share of foreign population, population density, and the average declared income, while $\gamma$ is a vector of control variables at the individual levels as in the previously discussed multinomial logistic regression.

Given the large number of models, for the sake of parsimony, in the text we will only report results concerning the main covariates of interest in graphical forms as we show either the unstarndardised regression coefficient of the average marginal effect. Full results are available in the appendix.

\section{Results}

In this section, we present our results. Given the large number of hypotheses that we need to test, the reader can find a summary of our hypotheses as well as the main results in table 3.

\begin{tabular}{|c|c|c|c|c|}
\hline Hyp. & Main DV & Main IV & Exp. sign & Results \\
\hline \multicolumn{5}{|c|}{ Local Welfare } \\
\hline $1 a$ & Center-Left scores & $\begin{array}{l}\text { Interaction term austerity } \mathrm{X} \text { per-capita } \\
\text { local spending }\end{array}$ & + & Sig. $(+)$ and robust \\
\hline \multirow[t]{3}{*}{$1 b$} & League scores & $\begin{array}{l}\text { Interaction term austerity } \mathrm{X} \text { per-capita } \\
\text { local spending }\end{array}$ & - & Not sig. \\
\hline & $\begin{array}{l}\text { Populist parties of the } \\
\text { right scores }\end{array}$ & $\begin{array}{l}\text { Interaction term austerity } \mathrm{X} \text { per-capita } \\
\text { local spending }\end{array}$ & - & Not sig. \\
\hline & Populist parties scores & $\begin{array}{l}\text { Interaction term austerity } \mathrm{X} \text { per-capita } \\
\text { local spending }\end{array}$ & - & Not sig. \\
\hline $2 a$ & Center-Left scores & $\begin{array}{l}\text { Interaction term austerity } \mathrm{X} \text { per-capita } \\
\text { local welfare spending }\end{array}$ & + & $\begin{array}{l}\text { Sig. }(+) \text { but not } \\
\text { robust }\end{array}$ \\
\hline \multirow[t]{3}{*}{$2 b$} & League scores & $\begin{array}{l}\text { Interaction term austerity } \mathrm{X} \text { per-capita } \\
\text { local welfare spending }\end{array}$ & - & Sig. (-) and robust \\
\hline & $\begin{array}{l}\text { Populist parties of the } \\
\text { right scores }\end{array}$ & $\begin{array}{l}\text { Interaction term austerity } \mathrm{X} \text { per-capita } \\
\text { local welfare spending }\end{array}$ & - & Sig. $(-)$ and robust \\
\hline & Populist parties scores & $\begin{array}{l}\text { Interaction term austerity } \mathrm{X} \text { per-capita } \\
\text { local welfare spending }\end{array}$ & - & Not sig. \\
\hline \multirow[t]{3}{*}{3} & Center-Left scores & $\begin{array}{l}\text { Interaction term austerity X per-capita } \\
\text { local spending by type }\end{array}$ & Edu (+) & Not sig. \\
\hline & League scores & $\begin{array}{l}\text { Interaction term austerity X per-capita } \\
\text { local spending by type }\end{array}$ & Edu (-) & $\begin{array}{l}\text { Edu (-), Law and } \\
\operatorname{Order}(+)\end{array}$ \\
\hline & $\begin{array}{l}\text { Populist parties of the } \\
\text { right scores }\end{array}$ & $\begin{array}{l}\text { Interaction term austerity } \mathrm{X} \text { per-capita } \\
\text { local spending by type }\end{array}$ & Edu (-) & $\begin{array}{l}\text { Edu }(-), \text { Law and } \\
\operatorname{Order}(+)\end{array}$ \\
\hline
\end{tabular}




\begin{tabular}{|c|c|c|c|c|}
\hline & Populist parties scores & $\begin{array}{l}\text { Interaction term austerity } \mathrm{X} \text { per-capita } \\
\text { local spending by type }\end{array}$ & Edu (-) & Not sig. \\
\hline $4 a$ & Center-Left scores & Interaction term austerity $\mathrm{X}$ inequality & - & Not sig. \\
\hline \multirow[t]{3}{*}{$4 \mathrm{~b}$} & League scores & Interaction term austerity $\mathrm{X}$ inequality & + & $\begin{array}{l}\text { Sig. }(+), \text { no } \\
\text { robustness checks }\end{array}$ \\
\hline & $\begin{array}{l}\text { Populist parties of the } \\
\text { right scores }\end{array}$ & Interaction term austerity $\mathrm{X}$ inequality & + & $\begin{array}{l}\text { Sig. (+), no } \\
\text { robustness checks }\end{array}$ \\
\hline & Populist parties scores & Interaction term austerity $\mathrm{X}$ inequality & + & $\begin{array}{l}\text { Sig. }(+) \text {, no } \\
\text { robustness checks }\end{array}$ \\
\hline \multicolumn{5}{|c|}{ Survey } \\
\hline $5 a$ & Voting preference & $\begin{array}{l}\text { Respondent's position on } 4 \\
\text { dimensions: } \\
\text { - Cultural cleavage } \\
\text { (libertarianism/ } \\
\text { traditionalism) } \\
\text { - Economic cleavage (state/ } \\
\text { market) } \\
\text { Transnational cleavage } \\
\text { (globalism / national focus) } \\
\text { Populist cleavage (populism } \\
\text { / elitism) }\end{array}$ & $\begin{array}{l}\text { Populist vote driven } \\
\text { by cultural concerns }\end{array}$ & $\begin{array}{l}\text { Cultural issues } \\
\text { distinguish } \\
\text { between populist } \\
\text { right and center- } \\
\text { left parties. } \\
\text { Econ cleavage } \\
\text { distinguishes } \\
\text { between types of } \\
\text { populism } \\
\text { (M5S/League) and } \\
\text { not sig. voting } \\
\text { pref. for center- } \\
\text { left parties. }\end{array}$ \\
\hline $5 b$ & $\begin{array}{l}\text { Respondent's position } \\
\text { on } 4 \text { dimensions: } \\
\text { - Cultural } \\
\text { cleavage } \\
\text { - Economic } \\
\text { cleavage } \\
\text { - Transnational } \\
\text { cleavage } \\
\text { Populist } \\
\text { cleavage }\end{array}$ & $\begin{array}{l}\text { - Local per-capita spending } \\
\text { - Average variation in local } \\
\text { per-capita spending between } \\
2008-2018 \\
\text { - Local inequality } \\
\text { - Average variation in local } \\
\text { inequality between 2008- } \\
2018\end{array}$ & $\begin{array}{l}\text { Areas that } \\
\text { experienced higher } \\
\text { cuts/saw inequality } \\
\text { increasing have } \\
\text { higher levels of } \\
\text { localism/nationalism } \\
\text { and populism. }\end{array}$ & Not sig. \\
\hline
\end{tabular}

Table 3. Summary of paper's main hypotheses and results.

\section{Hypotheses 1a-1b: local current spending}

Hypotheses 1a-b, 2a-b, 3 all concern the interaction between the austerity dummy and different types of local spending. We expected the interaction term to be significantly 
different from zero for both populist parties and the center-left but with opposite signs: positive for the center-left and negative for populist parties, where expenditures are concerned. In other words, we expect that, after the adoption of national austerity measures, the share of center-left parties should be higher in SLL where expenditures have been higher.

Figures $7 \mathrm{a}$ and $7 \mathrm{~b}$ report the average marginal effect and our results provide partial support for our hypotheses. The interaction coefficient for per-capita expenditures is significant and positive (as expected), regardless of whether we consider all national elections (Fig. 1) or Parliamentary elections only (Fig. 2). As such, after 2011 austerity, for every 100 euros of per-capita local spending in an SLL, the center-left saw its vote share increasing between $0.2 \%$ and $0.6 \%$. While the magnitude of this result is limited, we need to stress the fact that this is the effect of only one of the channels of transmission between austerity and politics and at the local, not national, level. Indeed, 100 euros represent just about $1 \%$ of the national per-capita government current spending. Interestingly, the interaction term is not significant for the League or any form of aggregation of populist parties. This seems to indicate that local expenditures first and foremost helped social-democratic and center-left forces in resisting the post-2011 political crisis, while as far populist parties are concerned local expenditures alone are not a sufficient mediator.

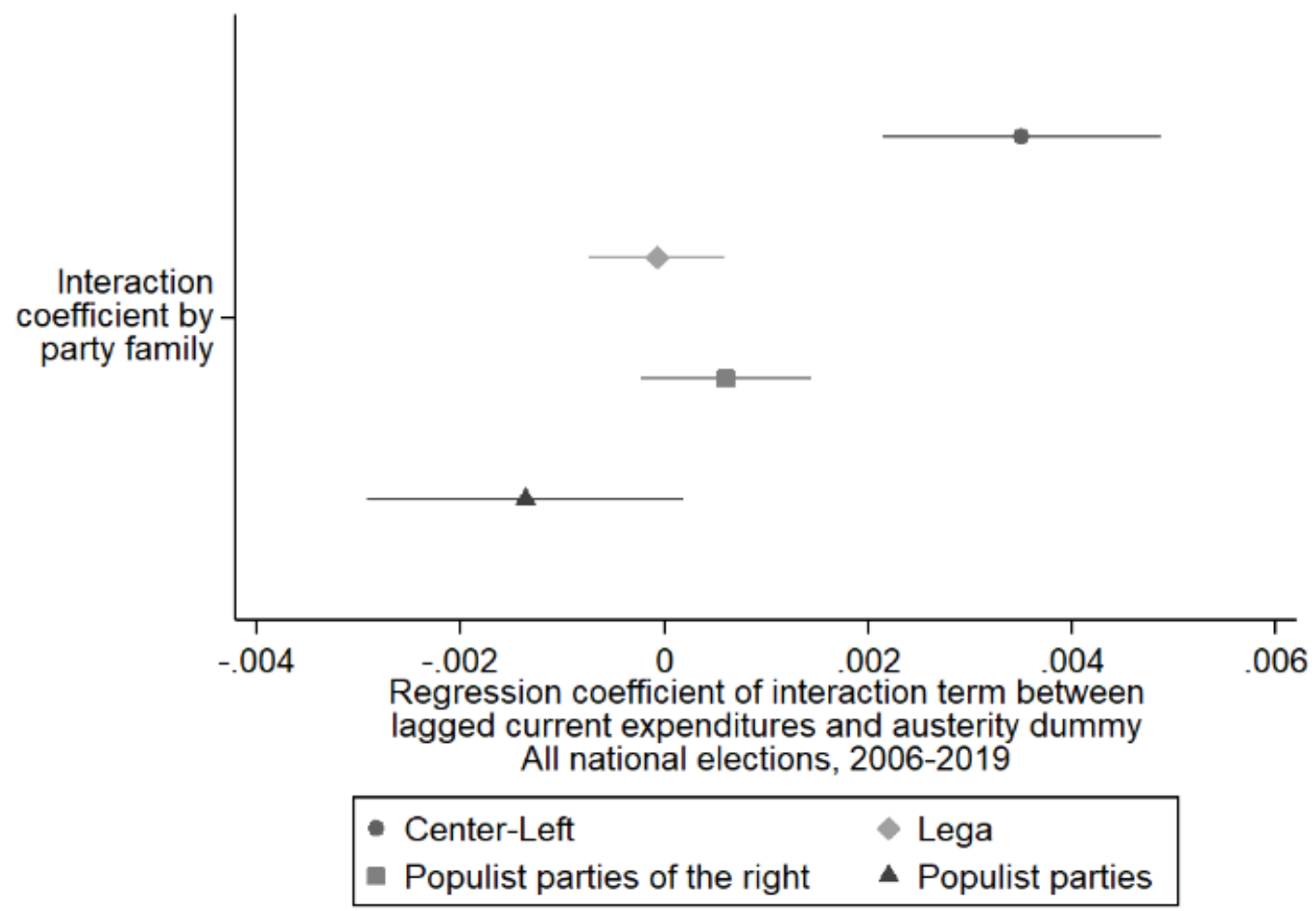

Fig. 7a-Regression coefficients of the interaction term between lagged local current expenditures and austerity dummy. 


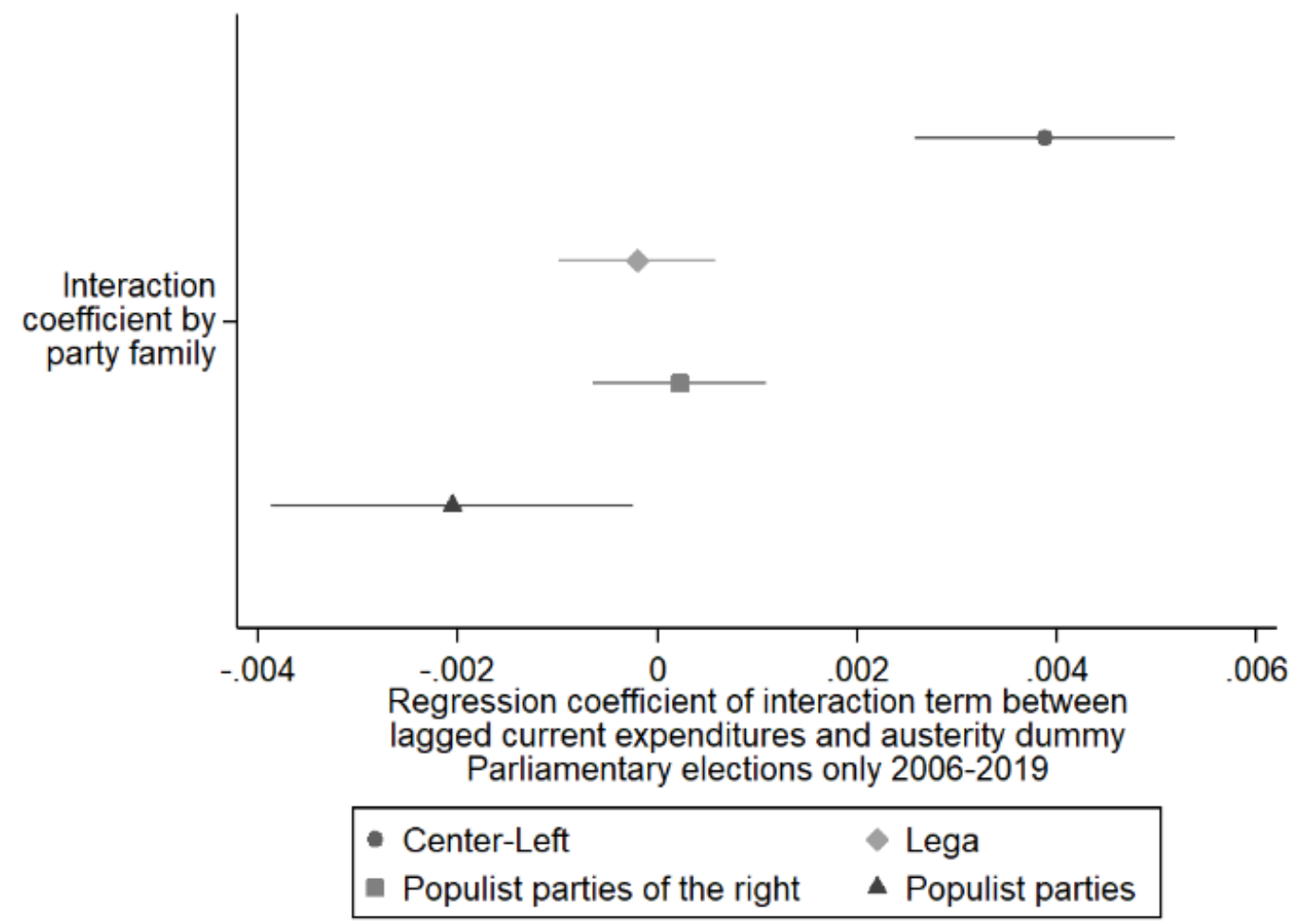

Fig. $7 b$ - Regression coefficients of the interaction term between lagged local current expenditures and austerity dummy. Parliamentary elections only.

\section{Hypotheses 2a-2b: welfare-related local expenditures}

Hypotheses $2 \mathrm{a}$ and $2 \mathrm{~b}$ focus on social spending, rather than on all current expenditures. The hypothesis is that center-left parties would be more helped by spending on social services rather than, for example, law enforcement. Results seem to confirm the hypotheses, although they appear to be less robust and are reported in Figures 8a and 8b. As we can see, following the Great Recession the center-left started being more competitive than before in SLLs where local social spending was higher. Interestingly, this time the interaction term turns out to be a significant (and negative) predictor for both the scores of the League and of populist radical right parties, although at different levels $(\mathrm{p}<0.01$ for the League and $\mathrm{p}<0.05$ for populist radical right parties). Results for the League are confirmed also when we focus on parliamentary elections only, while results for populist radical right parties are no longer significant. However, this is not the case for the center-left: while the coefficient of the interaction term is still positive, as expected, the larger confidence intervals do not allow us to distinguish it from zero at an acceptable level. An additional 100 euros per-capita spent on local social services, such as kindergartens or local transports, would translate in $-0.27 \%$ [95\% CI: $-0.55 \% /-0.01 \%$ ] of the vote share for radical right parties (League + FdI) and in a decrease of $-0.33 \%$ [ $95 \%$ CI: $-0.54 \% /-0.12 \%$ ] for the League. Finally, the interaction term in the model on populist parties in general turns out to be not significant. It would then appear that, in the Italian case, welfare-related local expenditures acted as a moderator for rightwing populism only and not populism as a whole. While the rise of the M5S might still be a 
consequence of national austerity policies, it does not seem that local welfare had any significant impact on it.

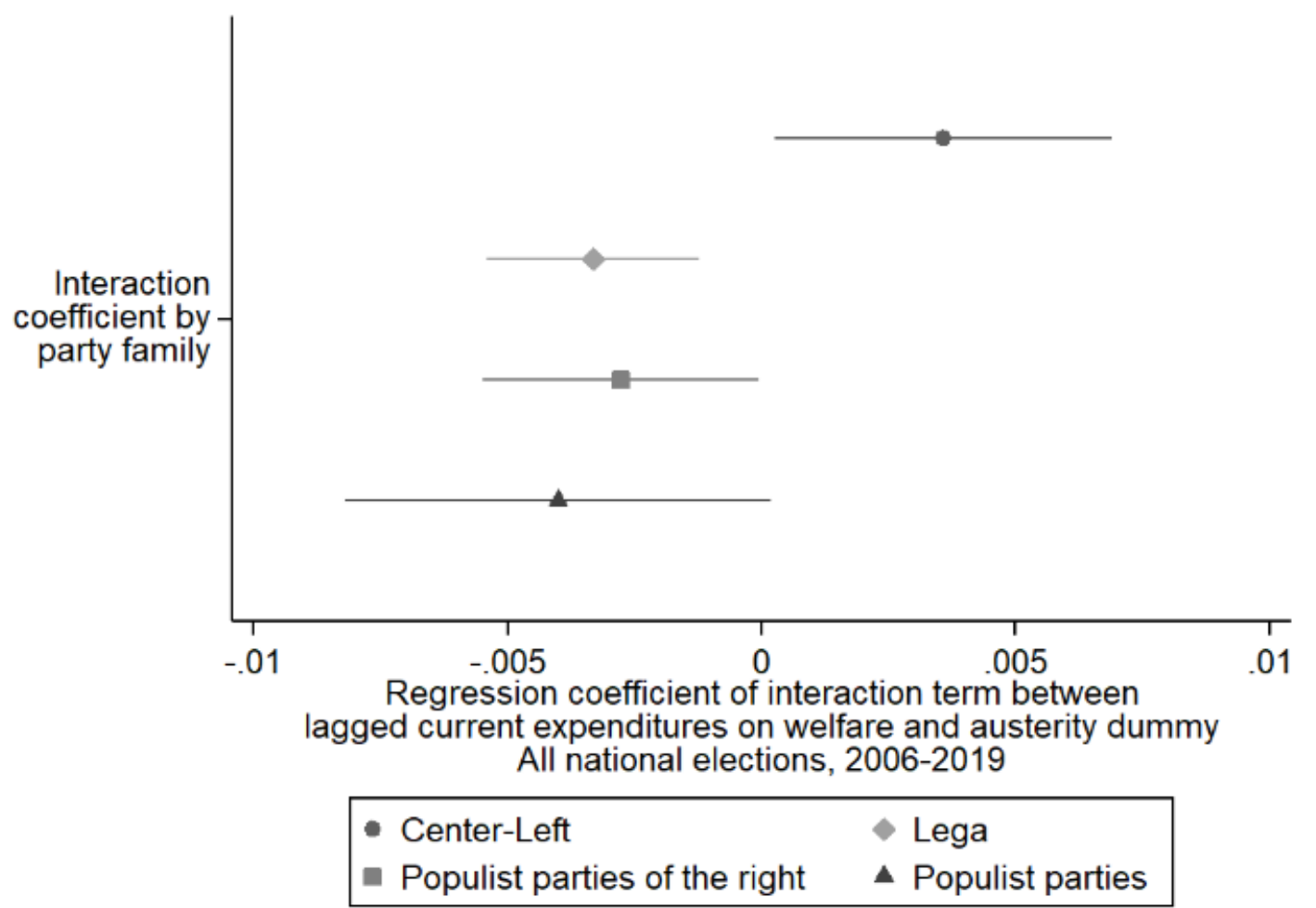

Fig. 8a-Regression coefficients of the interaction term between lagged local welfare expenditures and austerity dummy. 


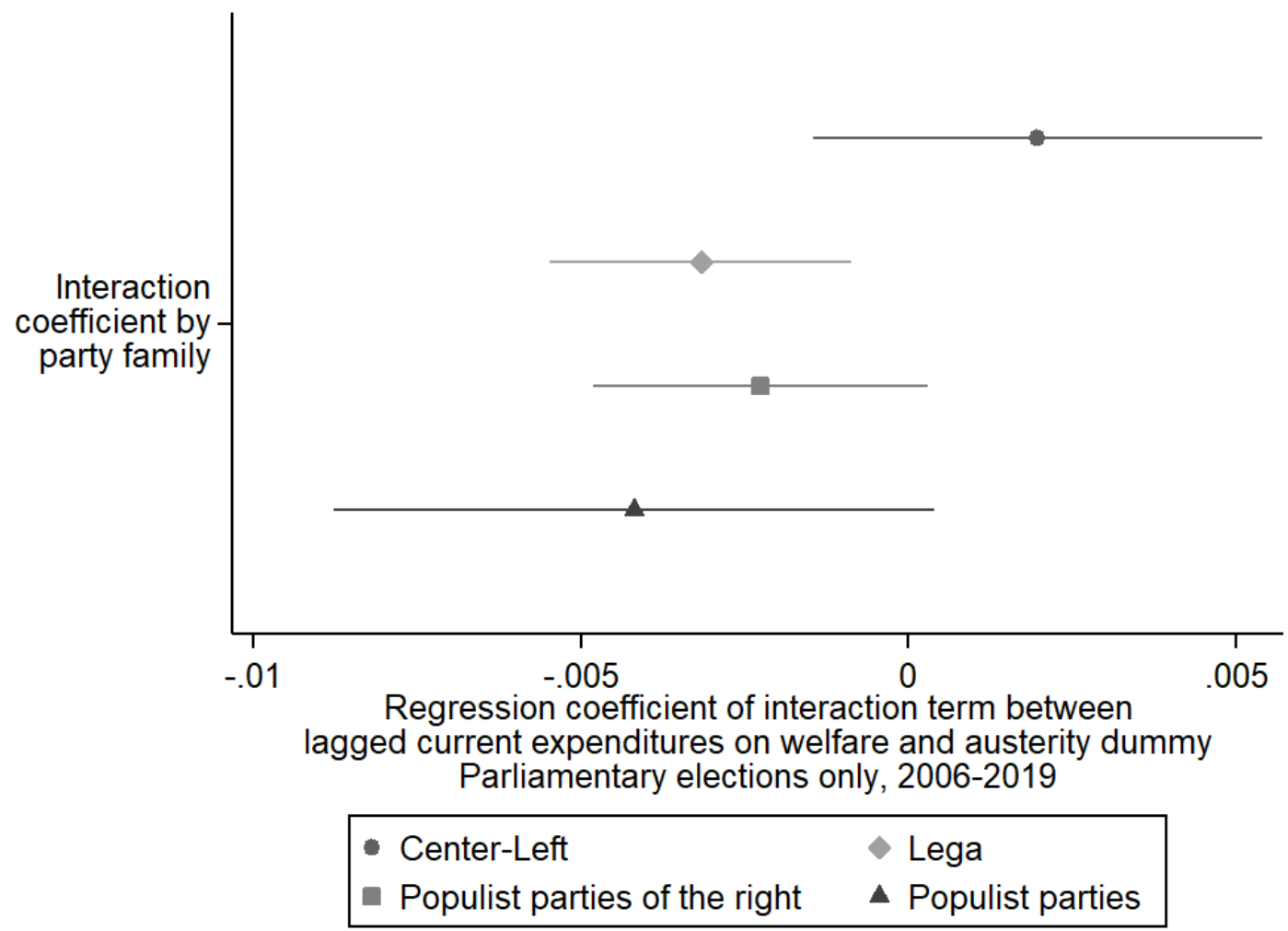

Fig. $8 b$ - Regression coefficients of the interaction term between lagged local welfare expenditures and austerity dummy. Parliamentary elections only.

\section{Hypotheses 3a-3b: type of local expenditures}

Finally, according to hypotheses 3 we expect to see significant differences depending on the exact type of service financed by local spending. Figures $3 a-3 b$ report results for the interaction term. While we are not able to observe a significant difference between pre- and post-2011 effects on any type of spending for center-left scores, results do show that the League and populist parties of the right performed worse in those areas where municipal spending on family and education were higher, compared to pre-austerity elections. These results are robust when European elections are excluded from the sample and the analysis focuses on Parliamentary elections only. At the same time, post-2011 right-wing populists' performance appear to be better in areas in which municipalities prioritized police funding as well as supply-side policies (subsidies to local agriculture and tourism for example, but the result is not robust once we focus on Parliamentary elections only). The League postcrisis increase would also appear to be negatively influenced by local spending on housing and public transport, thus actually pointing toward a more generally positive effect of social spending as a whole. 


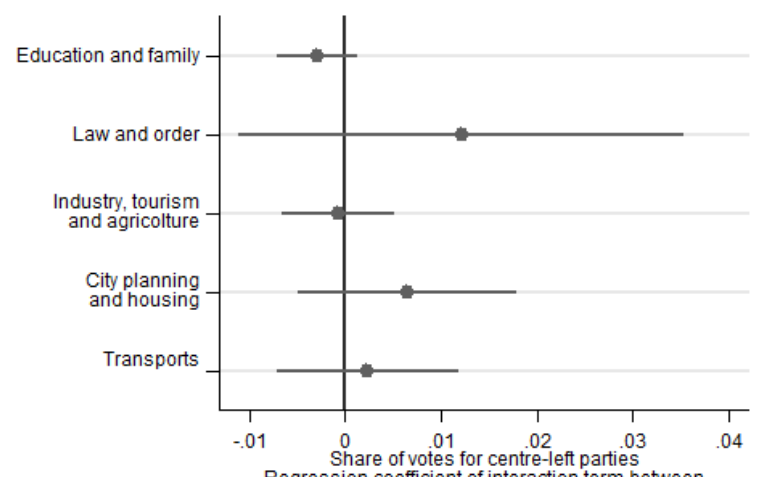
Regression coefficient of interaction term between
lagged local current expenditures by type and austerity dummy
All national elections.

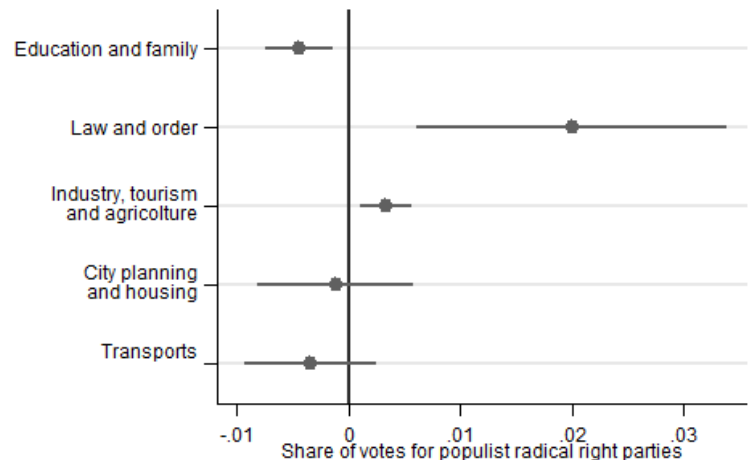

Share of votes for populist radical right parties Regression coefficient of interaction term between
lagged local current expenditures by type and austerity dummy All national elections.

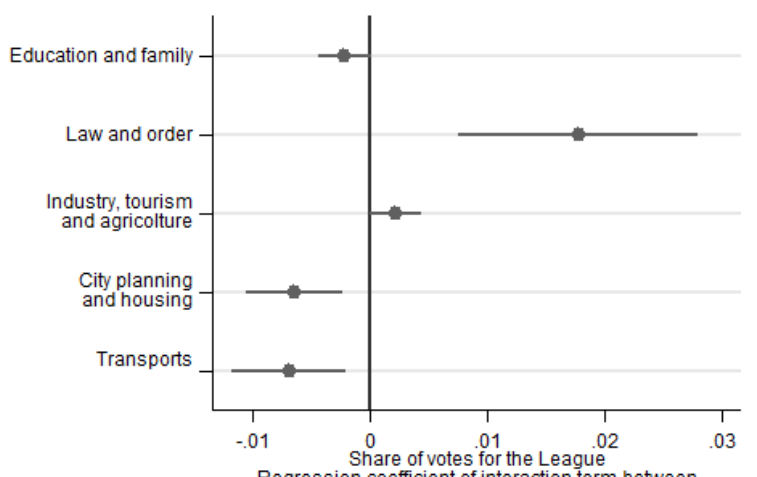

Regression coefficient of interaction term between
lagged local current expenditures by type and austerity dummy All national elections.

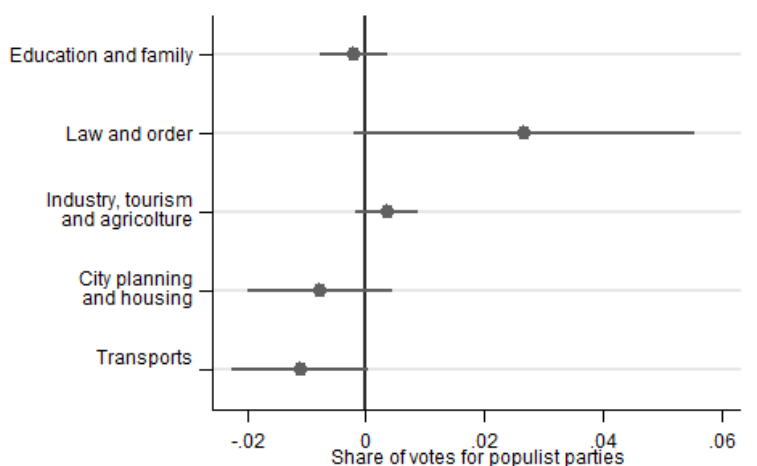
lagged local current expenditures by type and austerity dumm

Fig. 8a-Regression coefficients of the interaction term between lagged local welfare expenditures and austerity dummy. 

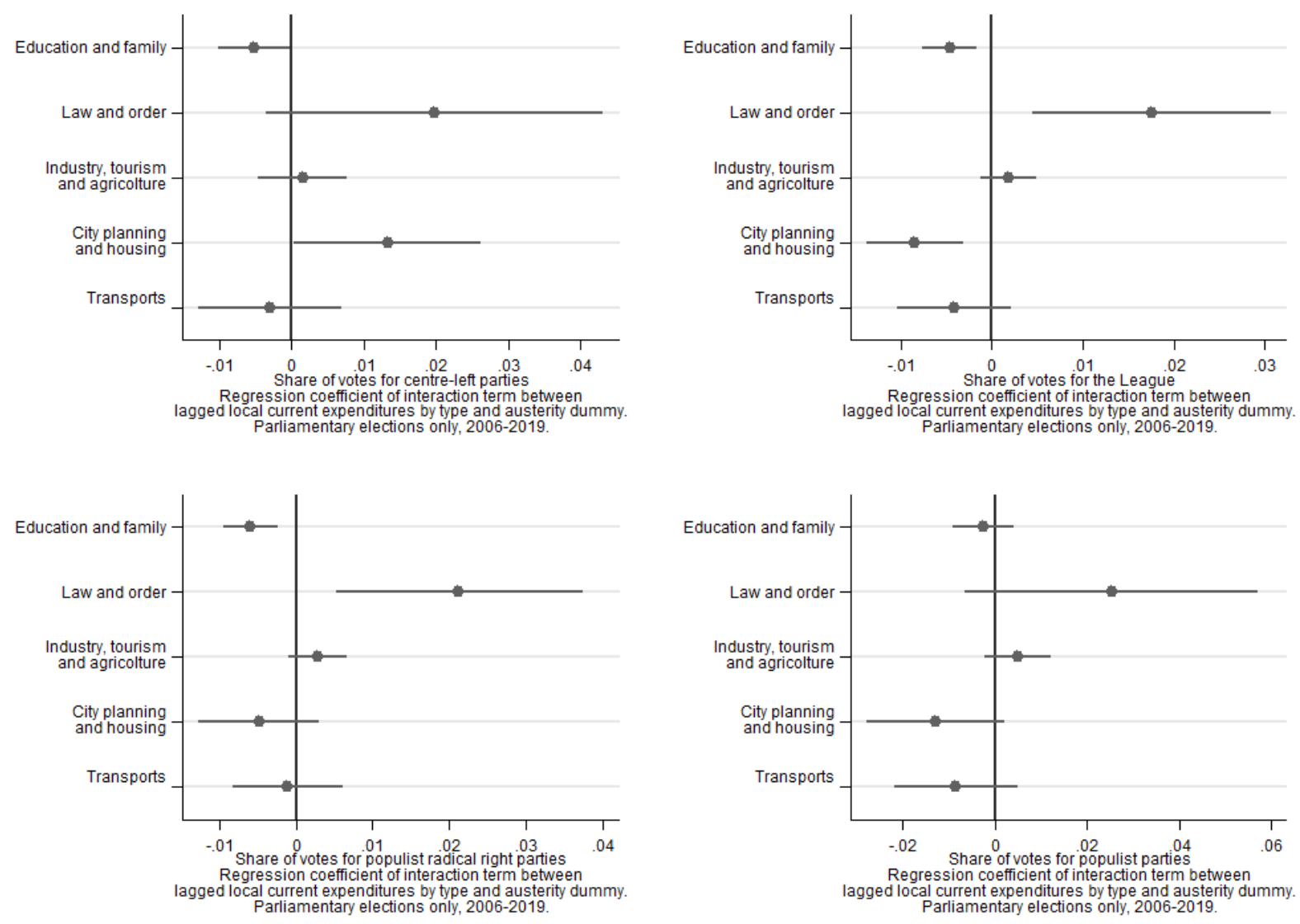

Fig. $8 b$ - Regression coefficients of the interaction term between lagged local welfare expenditures and austerity dummy. Parliamentary elections only.

\section{Hypotheses $4 a-4 b$ : inequality}

Hypotheses $4 \mathrm{a}$ and $4 \mathrm{~b}$ suggest that local inequality enhanced the national austerity shock, thus improving the scores for populist parties and worsening the crisis of center-left parties. As before, we focus on the interaction term between the Gini coefficient and a lagged austerity dummy. In this case, the interaction term is significant and positive for populist parties in different forms, while it is not significant for the center-left. An increase of 0.01 points in the Gini coefficient of the SLL, after 2011, would lead to an increase of $0.37 \%$ [95\% CI: $0.13 \%-0.62 \%$ ] in the vote share of all populist parties combined. Again, only part of the variation can be explained by local inequality. ${ }^{21}$

\footnotetext{
${ }^{21}$ For these hypotheses, we do not estimate the disaggregated effect for Parliamentary and European elections because data on the Gini coefficient starts from the year 2008: as such the lagged coefficient can only be used from the 2013 Parliamentary election, after the economic crisis.
} 


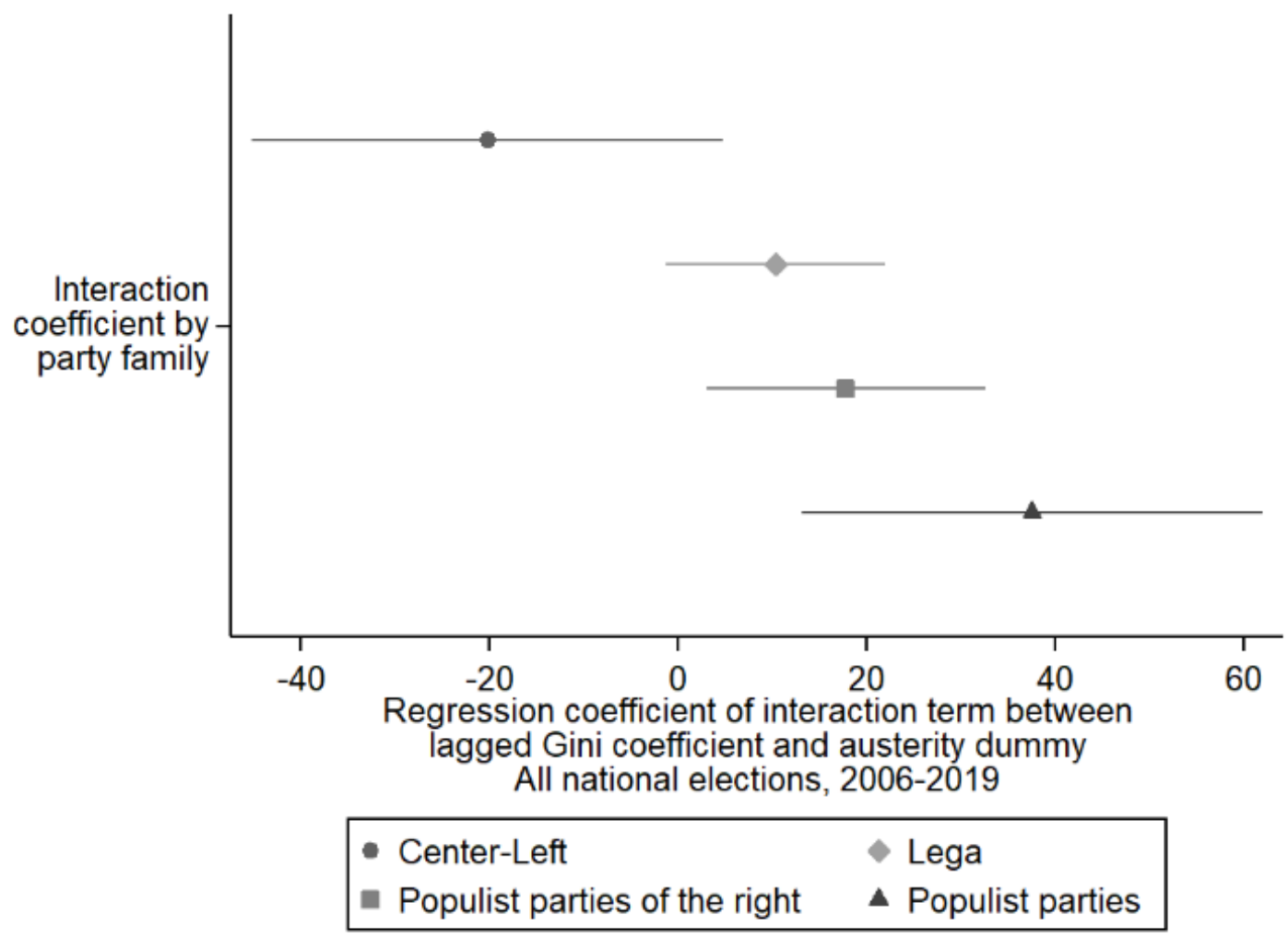

Fig. 9 - Regression coefficients of the interaction term between lagged inequality and austerity dummy.

\section{Hypotheses 5a-5b: the economy to cultural mechanism}

We conclude our analysis by moving away from aggregate data to check what the individuallevel mechanism might be. We do so by focusing on the results of a survey study, in order to see if the local economic environment influences voters' choice via a respondent's position on economic or non-economic issues. We start testing our hypothesis 5a, that stated that a voter's position on non-economic issues is a better predictor of a populist preference than a voter's position on economic topics. If we adopted a purely cultural reading of the phenomenon, we would expect the economic dimension to be insignificant once we controlled for the other dimensions and education. However, the picture is less clear than what we expected in Hypotheses 5a. Figure 10 shows the average marginal effects following a multinomial logit model where the party vote in the 2019 European Election was the dependent variable and four main dimensions of political conflict are the main independent variables. Results are quite unexpected: indeed, the average marginal effect on the probability of voting for center-left parties is significantly influenced by one's opinion on economic issues, although the coefficient is fairly low and center-left voters appear to mobilize mostly on the transnational cleavage. However, this is not the case for populist parties: as the dimension goes from more state to more market, it would seem that the economic dimension works in dividing the 'populist' camp in two: a more neo-liberal part (the League) and a more pro-state part (the M5S), rather than not having an effect at all. 
This indicates a more complex relationship than what may be expected by purely cultural readings of the populist phenomenon. This is not to say that the other dimensions are not relevant; on the contrary. But they are so in their own way. While the transnational cleavage clearly divides between the center-left and the League, the populist cleavage instead distinguishes a political space with the M5S on one pole and the Center-left on the other. Finally, the cultural dimension unifies the electorates of the center-left and the M5S juxtaposing them to those of the League and the other parties of the center-right. Overall, we see that at least in the context of a multiparty system with more than one populist party, there actually is a place for economic issues in explaining an individual's voting preference.

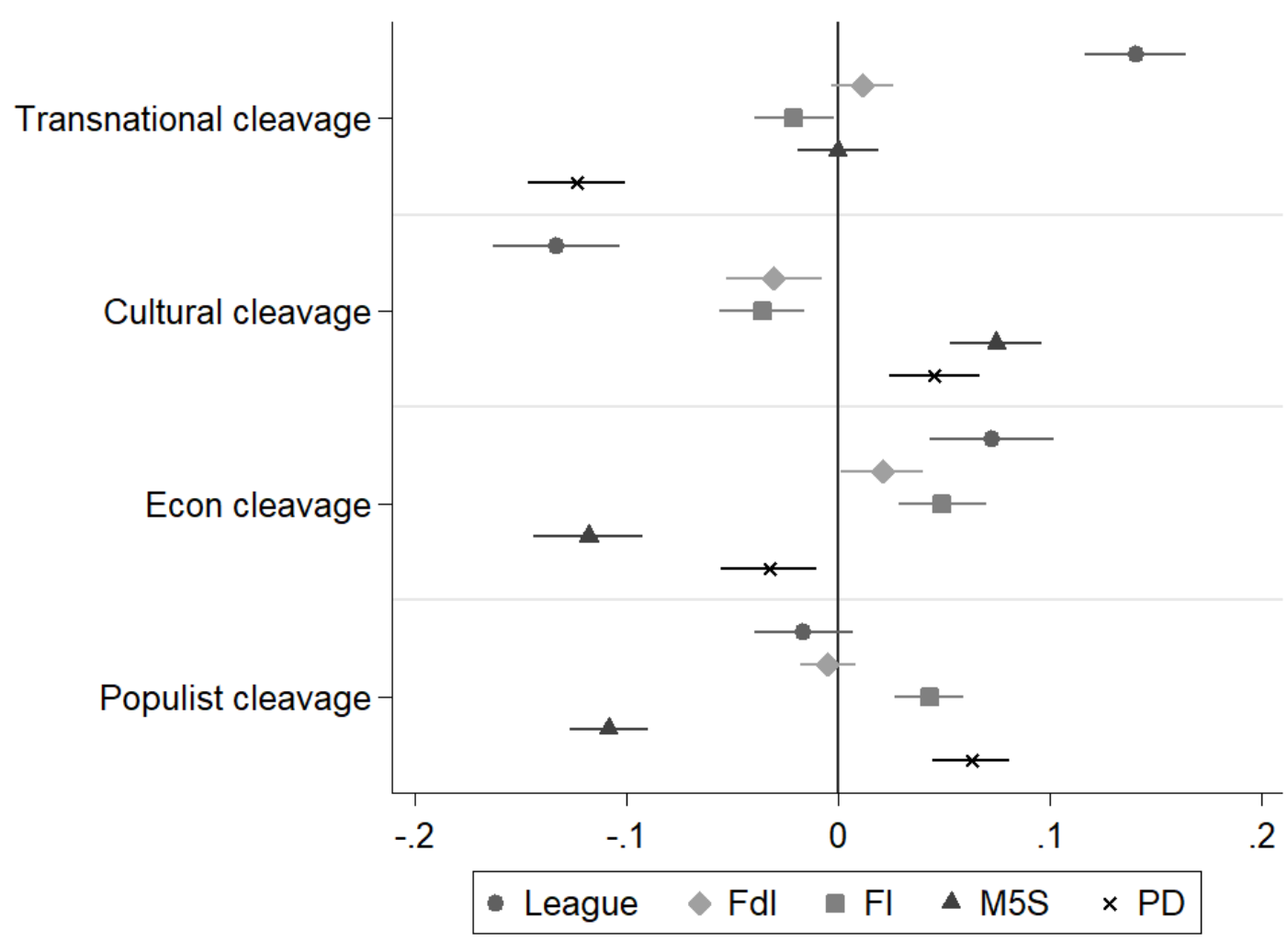

Fig. 10 - Average Marginal Effects of each cleavage on the probability of voting for the Center-Right, the League, the Center-Left or M5S.

Finally, with hypothesis $5 \mathrm{~b}$ we wish to ground our previous results that show a significant effect of the local economic environment in moderating the crisis of the center-left and the rise of populist parties in post-2011 Italy at the individual level. We look for a mechanism and we argue that the local economy, in terms of welfare and inequality, of a respondent's place of living could help steer his/her positions on different issues. Figure 11 reports our results and show that our tests were inconclusive. None of the provincial-level variables included in the OLS turns out to be significant: whether inequality or local current expenditures, in 2018 or their variation, none of what we thought could influence these dimensions seem to have a significant relationship with them. The mechanism stays hidden. 

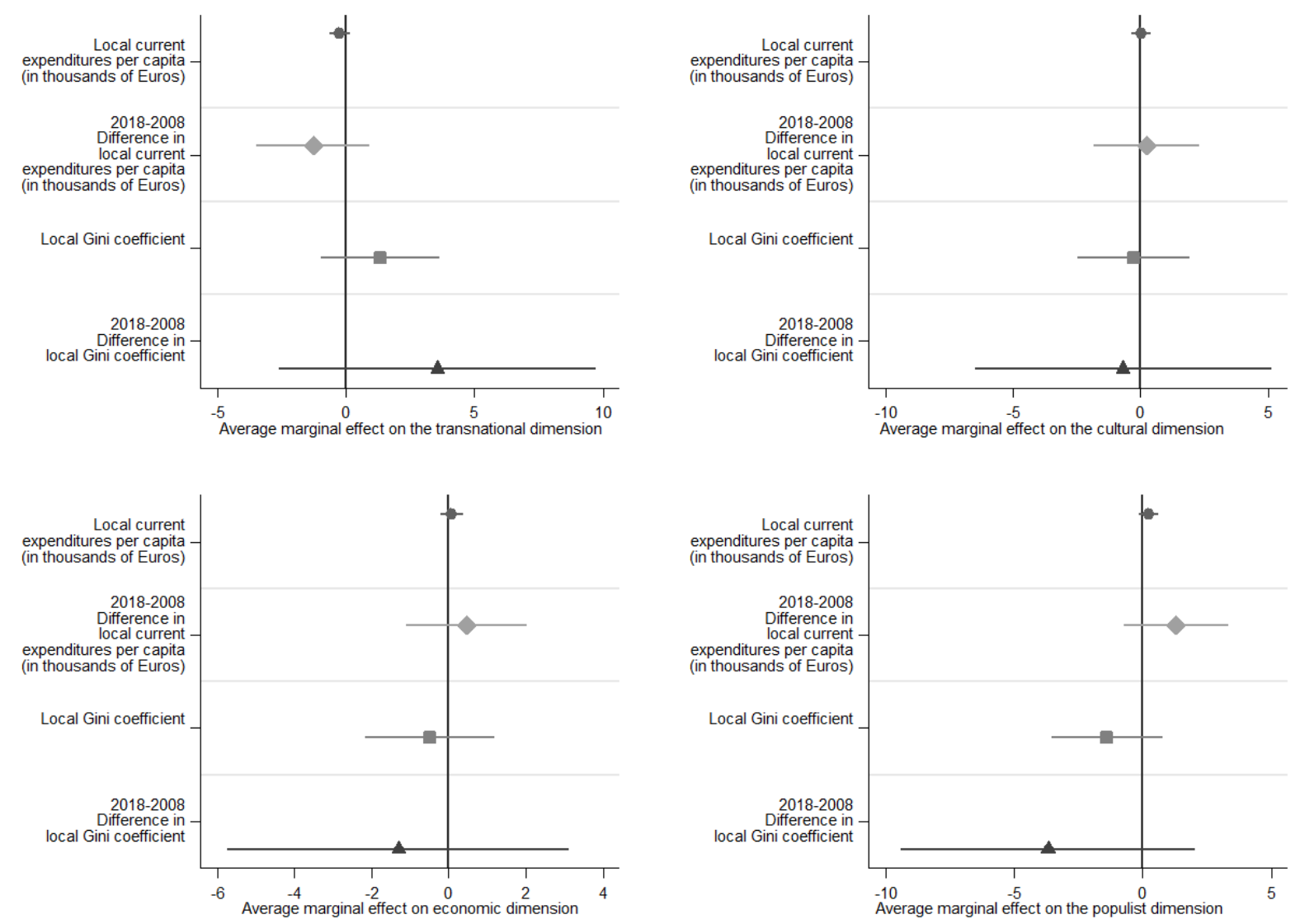

Fig. 11 - Average Marginal Effects of local current expenditures and local inequality on each dimension of political conflict.

\section{Conclusion}

In this paper we focused on the role of local level spending, particularly on local welfare, and local inequality as moderators for the Italian political crisis following the adoption of more radical national austerity measures in 2011. The theory that we wanted to test considered austerity as a national shock after which the Italian political system of the Second Republic crumbled, replaced by an unstable populist ascendency. Available data does not allow us to test the extent of the impact of national austerity. However, we can show using publicly available data that even the lowest level of welfare, the one offered by Italian municipalities, despite it being affected by austerity too, was still able to modulate this national shock. As such, municipalities with higher levels of expenditures following 2011 reforms were expected to see better results for center-left parties and worse scores for populist parties compared to pre-2011 elections. We applied the same reasoning to another possible mechanism of diffusion for populist votes: inequality, once again measured at the local level. In order to verify this idea, we built a dataset with data aggregated at the SLLlevel, as this unit better represents the area where voters live and interact than other (less meaningful in voters' life) administrative divisions. 
Our results indicate that there is a significant moderating role for both local welfare and inequality, although on different levels. Municipal current expenditures, particularly social spending, act as a significant moderator for center-left vote shares, increasing the post-2011 shares of the progressive coalition. We then, unsuccessfully, tried to understand if certain public services acted as better mediators than others, but obtained no significant result for the center left. Social spending, in particular on education, emerged instead as a significant moderator for the scores of populist radical right parties, while no significant results appeared for populist parties in general. Local inequality, instead, appears to significantly enhance scores for populist radical right parties and populist parties in general.

The overall magnitude of the effect is low and, given the extent of populist rise and the center-left decline in Italy one could easily argue that not much would have changed. But we think this is not the main lesson that one should take from our results. We explicitly looked at a David versus Goliath situation. We tested the role of the lowest level of welfare in slowing down the effect of the biggest electoral changes in the history of the Italian Republic, with the highest voting shares ever registered for populist parties and the worst result ever scored by progressive forces, following a clear acceleration in austerity policies and the largest GDP contraction since the end of the second world war. With such giant challenges, it seemed improbable that subsidies to local public transportation or kindergartens might have swayed significant numbers of people towards the center-left, or that living in a more equal area in terms of income might have influenced some people in not voting for the evergrowing populist parties. While we cannot claim causality, our results do indicate that at least in terms of correlation analysis there is instead a significant relationship between those things. And all of that at David's level.

In the second part of the paper, we looked for a possible mechanism and tested whether the local economic environment translated into different attitudes on four dimensions of conflict that structure the Italian political system: the role of the state (the economic dimension); openness to international organizations and migration (the transnational dimension); opinions on civil rights and morality (the cultural dimension); and trust in institutions and anti-establishment feelings (the populist dimension). As there is a debate in the literature on the role of economic and non-economic, i.e. cultural issues in influencing voting preferences for populist parties, we first ascertained the importance of economy-related topics in the Italian debate. We saw that economic issues in the Italian context distinguish between two types of populism: that of M5S and that of the League. This testifies to a more complex role for attitudes on economic issues than what one would expect in a purely cultural reading of populism. Still, other dimensions, too, played a role in shaping our respondents' voting preferences.

We then sought to connect the two levels, the individual and the local, by linking attitudes to the economic context. There, however, our study failed as we found no significant result. This could be due to limitations in our methodology because: a) in analysing survey data we move from the SLL to the province, an aggregation that is a less accurate depiction of the local environment where a respondent lives, and b) we only have data for 2019, meaning that we check if expenditures and inequality (or their variation) correlate with today's voters' 
opinion in the context of a single election, while the approach in the first part related to the capacity of absorbing the 2011 political shock across multiple elections. Unfortunately, Italy does not offer enough large longitudinal political surveys to test for attitudinal changes compared to pre-2011.

Overall, our study shows that even local authorities have a role to play in a globalized political world. If they actively pursue more solidarity and a more egalitarian society, they can intervene in slowing down the diffusion of populism, notably right-wing populism. Although we are still uncertain on how the channel of transmission between economics and politics works, we know it is there. As a corollary, however, we should also add that in extreme situations slowing down is not enough. In post-crisis Italy, David's small stone was not enough to kill the giant. 


\section{BIBLIOGRAPHY}

Abou-Chadi, Tarik, and Markus Wagner. 2020. 'Electoral Fortunes of Social Democratic Parties: Do Second Dimension Positions Matter?' Journal of European Public Policy 27 (2): 246-72. https://doi.org/10.1080/13501763.2019.1701532.

Albanese, Giuseppe, Guglielmo Barone, and Guido de Blasio. 2019. 'Populist Voting and Losers' Discontent: Does Redistribution Matter'. Dipartimento di Scienze Economiche" Marco Fanno".

Algan, Yann, Sergei Guriev, Elias Papaioannou, and Evgenia Passari. 2017. 'The European Trust Crisis and the Rise of Populism'. Brookings Papers on Economic Activity 2017 (2): 309-400.

Anderson, Joel, Ioannis Andreadis, Patrick Dumont, Andrea De Angelis, Jan Fivas, Thomas Fossen, Kostas Gemenis, Carolien Van Ham, Raphaël Kies, and André Krouwel. 2014. Matching Voters with Parties and Candidates: Voting Advice Applications in Comparative Perspective. Ecpr Press.

Ball, Laurence M., LBall@imf.org, Davide Furceri, DFurceri@imf.org, Daniel Leigh, DLeigh@imf.org, Prakash Loungani, and PLoungani@imf.org. 2013. 'The Distributional Effects of Fiscal Consolidation'. IMF Working Papers 13 (151): 1.

https://doi.org/10.5089/9781475551945.001.

Bergmann, Michael. 2011. IPFWEIGHT: Stata Module to Create Adjustment Weights for Surveys. Statistical Software Components. Boston College Department of Economics. https://ideas.repec.org/c/boc/bocode/s457353.html.

Bloise, Francesco, Daniela Chironi, and Mario Pianta. 2019. 'Inequality and Elections in Italian Regions'.

Bolgherini, Silvia. 2014. 'Can Austerity Lead to Recentralisation? Italian Local Government during the Economic Crisis'. South European Society and Politics 19 (2): 193-214. https://doi.org/10.1080/13608746.2014.895086.

Bordignon, Fabio, and Luigi Ceccarini. 2013. 'Five Stars and a Cricket. Beppe Grillo Shakes Italian Politics'. South European Society and Politics 18 (4): 427-49. https://doi.org/10.1080/13608746.2013.775720.

Bordignon, Fabio, Luigi Ceccarini, and Ilvo Diamanti. 2018. Le Divergenze Parallele. L'Italia: Dal Voto Devoto al Voto Liquido. Gius. Laterza \& Figli spa.

Bornschier, Simon. 2010. Cleavage Politics and the Populist Right. The New Cultural Conflict in Western Europe. Philadelphia: Temple University Press.

- - - 2018. 'Globalization, Cleavages, and the Radical Right'. The Oxford Handbook of the Radical Right, 212-38.

Caiani, Manuela, and Paolo R. Graziano. 2016. 'Varieties of Populism: Insights from the Italian Case'. Italian Political Science Review/Rivista Italiana Di Scienza Politica 46 (02): 243-67. https://doi.org/10.1017/ipo.2016.6.

Caselli, Mauro, Andrea Fracasso, and Silvio Traverso. 2020. 'Globalization and Electoral Outcomes: Evidence from Italy’. Economics \& Politics 32 (1): 68-103. 
Cataldi, Matteo, and Vincenzo Emanuele. 2013. 'Lo Tsunami Cambia La Geografia e Strappa 50 Province a Pd e Pdl'.

Cavaille, Charlotte, and Jeremy Ferwerda. 2018. 'How Distributional Conflict over In-Kind Benefits Generates Support for Anti-Immigrant Parties'. Working Paper.

Cavallaro, Matteo, Giovanni Diamanti, and Lorenzo Pregliasco. 2018. Una Nuova Italia. Castelvecchi Editore. Roma.

Cavallaro, Matteo, Davide Policastro, Guido Salza, and Massimo Angelo Zanetti. 2018.

'Le Fratture Socio-Politiche Alle Elezioni Politiche Del 2018: Preferenze Di Voto e

Posizionamento Tematico Delle Categorie Sociali'. In Le Elezioni Del 2018 : Partiti-

Candidati-Regole e Risultati, 112-36. Firenze: SISE.

https://www studielettorali.it/2018/DOMENICO\%20FRUNCILLO $\% 20 \mathrm{e} \% 20$ FELICE\%20

ADDEO-Le\%20elezioni\%20del\%202018-Partiti-candidati-regole\%20e\%20risultati-Sise2018.pdf.

Chiaramonte, Alessandro, and Lorenzo De Sio. 2019. Il Voto Del Cambiamento. Le Elezioni Politiche Del 2018. Il mulino.

Chiaramonte, Alessandro, and Vincenzo Emanuele. 2013. 'Volatile e tripolare: il nuovo sistema partitico italiano'. In Le elezioni politiche 2013, edited by Lorenzo De Sio, Matteo Cataldi, and Federico de Lucia, CISE, 95-100. Dossier CISE 4. Centro Italiano Studi Elettorali. https://cise.luiss.it/cise/2013/05/21/dossier-cise-le-elezioni-politiche-2013-isingoli-capitoli-in-pdf/.

Chiaramonte, Alessandro, Vincenzo Emanuele, Nicola Maggini, and Aldo Paparo. 2018. 'Populist Success in a Hung Parliament: The 2018 General Election in Italy'. South European Society and Politics 23 (4): 479-501. https://doi.org/10.1080/13608746.2018.1506513.

Colantone, Italo, and Piero Stanig. 2018. 'The Trade Origins of Economic Nationalism: Import Competition and Voting Behavior in Western Europe'. American Journal of Political Science. https://doi.org/10.1111/ajps.12358.

Conti, Nicolò, and Vincenzo Memoli. 2015. 'The Emergence of a New Party in the Italian Party System: Rise and Fortunes of the Five Star Movement'. West European Politics 38 (3): 516-34. https://doi.org/10.1080/01402382.2014.996377.

De Sio, Lorenzo. 2018. 'Il ritorno del voto di classe, ma al contrario (ovvero: se il PD è il partito delle élite)'. CISE (blog). 6 March 2018. https://cise.luiss.it/cise/2018/03/06/ilritorno-del-voto-di-classe-ma-al-contrario-ovvero-se-il-pd-e-il-partito-delle-elite/.

Del Pino, Eloisa, and Emmanuele Pavolini. 2015. 'Decentralization at a Time of Harsh Austerity: Multilevel Governance and the Welfare State in Spain and Italy Facing the Crisis'. European Journal of Social Security 17 (2): 246-70.

Di Feliciantonio, Cesare. 2016. 'Subjectification in Times of Indebtedness and Neoliberal/Austerity Urbanism'. Antipode 48 (5): 1206-27.

Diamanti, Ilvo. 2016. 'Mappe - Comunali 2016, Schemi Saltati e Confronti Incerti: Ecco Il Tripolarismo Imperfetto'. La Repubblica, 7 June 2016. http://www .demos.it/a01275.php. 
Dustmann, Christian, Barry Eichengreen, Sebastian Otten, André Sapir, Guido Tabellini, and Gylfi Zoega. 2017. 'Europe's Trust Deficit'. Causes and Remedies. London: Center for Economic Policy Research.

Eatwell, Roger, and Matthew Goodwin. 2018. National Populism: How Liberal Democracy Was Trumped (and What We Can Do about It). Penguin Books, Limited.

Eichengreen, Barry J. 2018. The Populist Temptation: Economic Grievance and Political Reaction in the Modern Era. London: Oxford University Press.

Elchardus, Mark, and Bram Spruyt. 2012. 'The Contemporary Contradictions of Egalitarianism: An Empirical Analysis of the Relationship between the Old and New Left/Right Alignments'. European Political Science Review: EPSR 4 (2): 217.

Ferguson, Thomas, Benjamin I. Page, Jacob Rothschild, Arturo Chang, and Jie Chen. 2020. 'The Roots of Right-Wing Populism: Donald Trump in 2016'. International Journal of Political Economy 49 (2): 102-23. https://doi.org/10.1080/08911916.2020.1778861.

Ferraresi, Massimiliano, Giuseppe Migali, Francesca Nordi, and Leonzio Rizzo. 2016. 'Spatial Interaction in Local Expenditures among Italian Municipalities: Evidence from Italy 2001-2011'.

Ferry, Laurence, Thomas Ahrens, and Rihab Khalifa. 2019. 'Public Value, Institutional Logics and Practice Variation during Austerity Localism at Newcastle City Council'. Public Management Review 21 (1): 96-115.

Fetzer, Thiemo. 2018. 'Did Austerity Cause Brexit?' 1170. Warwick Economics Research Papers Series. University of Warwick.

- - . 2019. 'Austerity Caused Brexit'. VoxEU.Org (blog). 8 April 2019. https://voxeu.org/article/austerity-caused-brexit.

Foster, Chase, and Jeffry Frieden. 2017. 'Crisis of Trust: Socio-Economic Determinants of Europeans' Confidence in Government'. European Union Politics 18 (4): 511-35.

- - . 2019. 'Compensation, Austerity, and Populism."'.

Furceri, Davide. 2015. Capital Account Liberalization and Inequality. International Monetary Fund.

Garzia, Diego, and Stefan Marschall. 2016. 'Research on Voting Advice Applications: State of the Art and Future Directions'. Policy \& Internet 8 (4): 376-90.

GIMBE. 2019. 'Il Definanziamento 2010-2019 Del Servizio Sanitario Nazionale'. 7. https://www.gimbe.org/osservatorio/Report_Osservatorio_GIMBE_2019.07_Definanziame nto_SSN.pdf.

Gray, Mia, and Anna Barford. 2018. 'The Depths of the Cuts: The Uneven Geography of Local Government Austerity'. Cambridge Journal of Regions, Economy and Society 11 (3): 541-63.

Guiso, Luigi, Helios Herrera, Massimo Morelli, and Tommaso Sonno. 2017. Demand and Supply of Populism. Center for Economic Policy Research London, UK. 
Hooghe, Liesbet, and Gary Marks. 2018. 'Cleavage Theory Meets Europe's Crises: Lipset, Rokkan, and the Transnational Cleavage'. Journal of European Public Policy 25 (1): 10935. https://doi.org/10.1080/13501763.2017.1310279.

Im, Zhen Jie, Nonna Mayer, Bruno Palier, and Jan Rovny. 2019. 'The "Losers of Automation": A Reservoir of Votes for the Radical Right?' Research \& Politics 6 (1): 2053168018822395. https://doi.org/10.1177/2053168018822395.

Inglehart, Ronald F., and Pippa Norris. 2016. 'Trump, Brexit, and the Rise of Populism: Economic Have-Nots and Cultural Backlash'. RWP16-026. Faculty Research Working Paper Series. Harvard.

ISTAT. 2015. 'Sistemi Locali Del Lavoro - Nota Metodologica'. https://www.istat.it/it/files//2014/12/nota-metodologica_SLL2011_rev20150205.pdf.

Ivaldi, Gilles, Maria Elisabetta Lanzone, and Dwayne Woods. 2017. 'Varieties of Populism across a Left-Right Spectrum: The Case of the Front National, the Northern League, Podemos and Five Star Movement'. Swiss Political Science Review 23 (4): 354-76.

Jaumotte, Florence, Subir Lall, and Chris Papageorgiou. 2013. 'Rising Income Inequality: Technology, or Trade and Financial Globalization?' IMF Economic Review 61 (2): 271-309. https://doi.org/10.1057/imfer.2013.7.

Jesuit, David K., Piotr R. Paradowski, and Vincent A. Mahler. 2009. 'Electoral Support for Extreme Right-Wing Parties: A Sub-National Analysis of Western European Elections'. Electoral Studies 28 (2): 279-90. https://doi.org/10.1016/j.electstud.2009.01.009.

Johnston, Ron, Charles Pattie, Kelvyn Jones, and David Manley. 2017. 'Was the 2016 United States' Presidential Contest a Deviating Election? Continuity and Change in the Electoral Map - or "Plus Ça Change, plus ç'est La Mème Géographie". Journal of Elections, Public Opinion and Parties 27 (4): 369-88. https://doi.org/10.1080/17457289.2017.1354004.

Johnston, Ron, David Rossiter, David Manley, Charles Pattie, Todd Hartman, and Kelvyn Jones. 2018. 'Coming Full Circle: The 2017 UK General Election and the Changing Electoral Map'. The Geographical Journal 184 (1): 100-108. https://doi.org/10.1111/geoj.12240.

Kennett, Patricia, Gerwyn Jones, Richard Meegan, and Jacqui Croft. 2015. 'Recession, Austerity and the "Great Risk Shift": Local Government and Household Impacts and Responses in Bristol and Liverpool'. Local Government Studies 41 (4): 622-44.

Kim, Yunji, and Mildred E. Warner. 2020. 'Pragmatic Municipalism or Austerity Urbanism? Understanding Local Government Responses to Fiscal Stress'. Local Government Studies, February, 1-19. https://doi.org/10.1080/03003930.2020.1729751.

Levi, Eugenio, and Fabrizio Patriarca. 2020. 'An Exploratory Study of Populism: The Municipality-Level Predictors of Electoral Outcomes in Italy'. Economia Politica, July. https://doi.org/10.1007/s40888-020-00191-8.

Lipset, Seymour M, and Stein Rokkan. 1967. 'Cleavage Structures, Party Systems, and Voter Alignments: An Introduction'.

Lucassen, G., and M. Lubbers. 2011. 'Who Fears What? Explaining Far-Right-Wing Preference in Europe by Distinguishing Perceived Cultural and Economic Ethnic Threats'. Comparative Political Studies 45 (5): 547-74. https://doi.org/10.1177/0010414011427851. 
Malgouyres, Clément. 2017. 'Trade Shocks and Far-Right Voting: Evidence from French Presidential Elections'. SSRN Scholarly Paper ID 2942173. Rochester, NY: Social Science Research Network. https://doi.org/10.2139/ssrn.2942173.

MEF. 2019. 'Commento Ai Principal Dati Del Conto Annuale Del Periodo 2009-2018'. Ministero dell'Economia e delle Finanze.

https://www.contoannuale.mef.gov.it/ext/Documents/ANALISI\%20E\%20COMMENTI\%2 02009-2018.pdf.

Morris, Jonathan, John Harrison, Andrea Genovese, Liam Goucher, and SCL Koh. 2017. 'Energy Policy under Austerity Localism: What Role for Local Authorities?' Local Government Studies 43 (6): 882-902.

Mudde, Cas. 2007. Populist Radical Right Parties in Europe. Cambridge: Cambridge Univ. Press.

Mudde, Cas, and Cristóbal Rovira Kaltwasser. 2017. Populism: A Very Short Introduction. Oxford University Press.

Oesch, Daniel, and Line Rennwald. 2018. 'Electoral Competition in Europe's New Tripolar Political Space: Class Voting for the Left, Center-Right and Radical Right'. European Journal of Political Research. https://doi.org/10.1111/1475-6765.12259.

Pastor, Lubos, and Pietro Veronesi. 2018. 'Inequality Aversion, Populism, and the Backlash against Globalization’. 0898-2937. National Bureau of Economic Research.

Peck, Jamie. 2014. 'Pushing Austerity: State Failure, Municipal Bankruptcy and the Crises of Fiscal Federalism in the USA'. Cambridge Journal of Regions, Economy and Society 7 (1): 17-44.

Perrineau, Pascal, and Nonna Mayer. 1996. Le Front national à découvert, $2 e$ édition. Paris: Presses de la Fondation nationale des sciences politiques.

Pianzola, Joëlle. 2014. 'Selection Biases in Voting Advice Application Research'. Electoral Studies 36: 272-80.

Piketty, Thomas. 2018. 'Brahmin Left vs Merchant Right: Rising Inequality \& the Changing Structure of Political Conflict'. 2018/7. WID WP Series.

Pol, Jasper van de, Bregje Holleman, Naomi Kamoen, André Krouwel, and Claes de Vreese. 2014. 'Beyond Young, Highly Educated Males: A Typology of VAA Users'. Journal of Information Technology \& Politics 11 (4): 397-411. https://doi.org/10.1080/19331681.2014.958794.

Pollio, Andrea. 2016. 'Technologies of Austerity Urbanism: The "Smart City" Agenda in Italy (2011-2013)'. Urban Geography 37 (4): 514-34.

Rennwald, Line. 2020. 'Renewing Social Democracy by Re-Mobilising the Working Class?' In Social Democratic Parties and the Working Class: New Voting Patterns, edited by Line Rennwald, 89-101. Challenges to Democracy in the 21st Century. Cham: Springer International Publishing. https://doi.org/10.1007/978-3-030-46239-0_6.

Rodrik, Dani. 1997. 'Trade, Social Insurance, and the Limits to Globalization' . 5905. NBER Working Paper Series. National Bureau of Economic Research. 
- - - . 2020. 'Why Does Globalization Fuel Populism? Economics, Culture, and the Rise of Right-Wing Populism'. 0898-2937. National Bureau of Economic Research.

Rooduijn, Matthijs, Stijn Van Kessel, Caterina Froio, Andrea Pirro, Sarah L. De Lange, Daphne Halikiopoulou, Paul Lewis, Cas Mudde, and Paul Taggart. 2019. 'The PopuList: An Overview of Populist, Far Right, Far Left and Eurosceptic Parties in Europe'. https://populist.org/.

Rydgren, Jens. 2007. 'The Sociology of the Radical Right'. Annu. Rev. Sociol. 33: 241-262. - - - ed. 2012. Class Politics and the Radical Right. London: Routledge.

Saraceno, Francesco. 2020. La Riconquista. LUISS University Press. https://www.luissuniversitypress.it/pubblicazioni/la-riconquista.

Sheppard, Jill. 2018. Measuring Social Attitudes with Voter Advice Application Data. ANU Center for Social Research \& Methods.

Storm, Servaas. 2019. 'Lost in Deflation: Why Italy's Woes Are a Warning to the Whole Eurozone'. International Journal of Political Economy 48 (3): 195-237. https://doi.org/10.1080/08911916.2019.1655943.

Tarchi, Marco. 2008. 'Italy: A Country of Many Populisms'. In Twenty-First Century Populism, 84-99. Springer.

Truglia, Francesco Giovanni, and Alessandro Zeli. 2020. 'Spatial Analysis of Economic and Social Determinants of Vote: The Case of the European Parliament and Constitutional Referendum Votes in Italy'. Italian Political Science Review / Rivista Italiana Di Scienza Politica 50 (2): 173-90. https://doi.org/10.1017/ipo.2019.29.

Van Hamme, Gilles, Christian Vandermotten, and Pablo Medina Lockhart. 2018. 'The Electoral Geography of the Left in Western Europe Since 1945: Permanencies and Changes'. Tijdschrift Voor Economische En Sociale Geografie 109 (2): 274-94. https://doi.org/10.1111/tesg.12280.

Verbeek, Bertjan, and Andrej Zaslove. 2015. 'Italy: A Case of Mutating Populism?' Democratization 0 (0): 1-20. https://doi.org/10.1080/13510347.2015.1076213.

Vlandas, Tim, and Daphne Halikiopoulou. 2016. 'Why Far Right Parties Do Well at Times of Crisis: The Role of Labor Market Institutions'.

https://papers.ssrn.com/sol3/papers.cfm?abstract_id=2854926.

Wheatley, Jonathan. 2016. 'Cleavage Structures and Dimensions of Ideology in English Politics: Evidence from Voting Advice Application Data'. Policy \& Internet 8 (4): 457-77.

Wheatley, Jonathan, and Micha Germann. 2014. 'Adjusting for Sample Bias in VAA Datasets: Can It Be Done and Does It Matter?' In . Glasgow.

Woo, Jaejoon, Elva Bova, Tidiane Kinda, Prepared Jaejoon Woo, Elva Bova, Tidiane Kinda, Y. Sophia Zhang, et al. 2013. Fiscal Affairs Department Distributional Consequences of Fiscal Consolidation and the Role of Fiscal Policy: What Do the Data Say? *.

Wurthmann, L. Constantin, Stefan Marschall, Vasiliki Triga, and Vasilis Manavopoulos. 2020. 'Many Losers - One Winner? An Examination of Vote Switching to the AfD in the 
2017 German Federal Election Using VAA Data'. Party Politics, April, 1354068820914959. https://doi.org/10.1177/1354068820914959. 


\section{APPENDIX}

Table 1 . Spending by category.

\begin{tabular}{|c|c|c|c|c|}
\hline Pre-2015 version & Harmonized version & $\begin{array}{l}\text { English translation } \\
\text { (Harm. Version) }\end{array}$ & $\begin{array}{l}\text { Social } \\
\text { Spending? }\end{array}$ & Category \\
\hline $\begin{array}{l}\text { Funzioni generali di amministrazione di } \\
\text { gestione e di controllo }\end{array}$ & $\begin{array}{l}\text { MISSIONE } 1 \text { - Servizi istituzionali, generali e } \\
\text { di gestione }\end{array}$ & Management & NO & OTHER \\
\hline Funzioni relative alla giustizia & MISSIONE 2 - Giustizia & Justice & NO & LAW AND JUSTICE \\
\hline Funzioni di polizia locale & MISSIONE 3 - Ordine pubblico e sicurezza & Public order & NO & LAW AND JUSTICE \\
\hline Funzioni di istruzione pubblica & MISSIONE 4 - Istruzione e diritto allo studio & Education & YES & EDUCATION \\
\hline $\begin{array}{l}\text { Funzioni relative alla cultura ed ai beni } \\
\text { culturali }\end{array}$ & $\begin{array}{l}\text { MISSIONE } 5 \text { - Tutela e valorizzazione dei } \\
\text { beni e delle attività culturali }\end{array}$ & Culture & YES & EDUCATION \\
\hline Funzioni nel settore sportivo e ricreativo & $\begin{array}{l}\text { MISSIONE } 6 \text { - Politiche giovanili, sport e } \\
\text { tempo libero }\end{array}$ & Sport and Youth & YES & EDUCATION \\
\hline Funzioni nel campo turistico & MISSIONE 7 - Turismo & Tourism & NO & $\begin{array}{l}\text { PRODUCTION } \\
\text { AND TOURISM }\end{array}$ \\
\hline $\begin{array}{l}\text { Funzioni nel campo della viabilità e dei } \\
\text { trasporti }\end{array}$ & $\begin{array}{l}\text { MISSIONE } 10 \text { - Trasporti e diritto alla } \\
\text { mobilità }\end{array}$ & Public Transport & YES & TRANSPORT \\
\hline Urbanistica e gestione del territorio & $\begin{array}{l}\text { MISSIONE } 8 \text { - Assetto del territorio ed } \\
\text { edilizia abitativa }\end{array}$ & $\begin{array}{l}\text { Land use and } \\
\text { housing }\end{array}$ & NO & $\begin{array}{l}\text { CITY PLANNING } \\
\text { AND HOUSING }\end{array}$ \\
\hline $\begin{array}{l}\text { Edilizia residenziale pubblica e locale e } \\
\text { piani di edilizia economica-popolare }\end{array}$ & $\begin{array}{l}\text { MISSIONE } 8 \text { - Assetto del territorio ed } \\
\text { edilizia abitativa }\end{array}$ & $\begin{array}{l}\text { Land use and } \\
\text { housing }\end{array}$ & YES & $\begin{array}{l}\text { CITY PLANNING } \\
\text { AND HOUSING }\end{array}$ \\
\hline Servizio di protezione civile & MISSIONE 11 - Soccorso civile & Civil protection & NO & OTHER \\
\hline Servizio idrico integrato & $\begin{array}{l}\text { MISSIONE } 8 \text { - Assetto del territorio ed } \\
\text { edilizia abitativa }\end{array}$ & $\begin{array}{l}\text { Land use and } \\
\text { housing }\end{array}$ & NO & $\begin{array}{l}\text { CITY PLANNING } \\
\text { AND HOUSING }\end{array}$ \\
\hline Servizio smaltimento rifiuti & $\begin{array}{l}\text { MISSIONE } 9 \text { - Sviluppo sostenibile e tutela } \\
\text { del territorio e dell'ambiente }\end{array}$ & $\begin{array}{l}\text { Sustainable } \\
\text { development and } \\
\text { environmental } \\
\text { protection }\end{array}$ & NO & $\begin{array}{l}\text { SUSTAINABLE } \\
\text { DEVELOPMENT } \\
\text { AND } \\
\text { ENVIRONMENTAL } \\
\text { PROTECTION }\end{array}$ \\
\hline $\begin{array}{l}\text { Parchi e servizi per la tutela ambientale } \\
\text { del verde. altri servizi relativi al territorio } \\
\text { ed all'ambiente }\end{array}$ & $\begin{array}{l}\text { MISSIONE } 9 \text { - Sviluppo sostenibile e tutela } \\
\text { del territorio e dell'ambiente }\end{array}$ & $\begin{array}{l}\text { Sustainable } \\
\text { development and } \\
\text { environmental } \\
\text { protection }\end{array}$ & NO & $\begin{array}{l}\text { SUSTAINABLE } \\
\text { DEVELOPMENT } \\
\text { AND } \\
\text { ENVIRONMENTAL } \\
\text { PROTECTION }\end{array}$ \\
\hline Funzioni nel settore sociale & $\begin{array}{l}\text { MISSIONE } 12 \text { - Diritti sociali, politiche } \\
\text { sociali e famiglia }\end{array}$ & Social policy & YES & EDUCATION \\
\hline - & MISSIONE 13 - Tutela della salute & Healthcare & YES & OTHER \\
\hline $\begin{array}{l}\text { Funzioni nel campo dello sviluppo } \\
\text { economico }\end{array}$ & $\begin{array}{l}\text { MISSIONE } 14 \text { - Sviluppo economico e } \\
\text { competitività }\end{array}$ & $\begin{array}{l}\text { Competitiveness } \\
\text { and growth }\end{array}$ & NO & $\begin{array}{l}\text { PRODUCTION } \\
\text { AND TOURISM }\end{array}$ \\
\hline - & $\begin{array}{l}\text { MISSIONE } 15 \text { - Politiche per il lavoro e la } \\
\text { formazione professionale }\end{array}$ & $\begin{array}{l}\text { Labor market and } \\
\text { vocational training }\end{array}$ & YES & EDUCATION \\
\hline Funzioni relative a servizi produttivi & $\begin{array}{l}\text { MISSIONE } 16 \text { - Agricoltura, politiche } \\
\text { agroalimentari e pesca }\end{array}$ & Agriculture & NO & $\begin{array}{l}\text { PRODUCTION } \\
\text { AND TOURISM }\end{array}$ \\
\hline - & $\begin{array}{l}\text { MISSIONE } 17 \text { - Energia e diversificazione } \\
\text { delle fonti energetiche }\end{array}$ & Energy & NO & OTHER \\
\hline
\end{tabular}




\begin{tabular}{|l|l|l|l|l|}
\hline- & $\begin{array}{l}\text { MISSIONE 18 - Relazioni con le altre } \\
\text { autonomie territoriali e locali }\end{array}$ & $\begin{array}{l}\text { Interterritorial } \\
\text { relations }\end{array}$ & NO & OTHER \\
\hline- & MISSIONE $19-$ Relazioni internazionali & $\begin{array}{l}\text { International } \\
\text { relations }\end{array}$ & NO & OTHER \\
\hline- & MISSIONE 20 - Fondi e accantonamenti & $\begin{array}{l}\text { Funds and } \\
\text { provisions }\end{array}$ & NO & OTHER \\
\hline- & MISSIONE 50 - Debito pubblico & Public debt & NO & OTHER \\
\hline- & MISSIONE 60 - Anticipazioni finanziarie & Down-payments & NO & OTHER \\
\hline
\end{tabular}


Table 2. Descriptive statistics of local data.

\begin{tabular}{l|rrr} 
Variable & Mean & $\begin{array}{c}\text { Standard } \\
\text { Deviation }\end{array}$ & Observations \\
\hline Center-left & $33,2 \%$ & $11,3 \%$ & 4255 \\
League & $11,6 \%$ & $14,0 \%$ & 4255 \\
Populist parties of the right & $14,0 \%$ & $15,6 \%$ & 4255 \\
All populist & $27,7 \%$ & $22,6 \%$ & 4255 \\
Per-capita local current spending & $902,3 €$ & $361,9 €$ & 4270 \\
Per-capita local social spending & $305,7 €$ & $136,0 €$ & 4270 \\
Per capita local spending on education & $228,5 €$ & $112,3 €$ & 4270 \\
Per capita local spending on justice & $44,4 €$ & $18,7 €$ & 4270 \\
Per capita local spending on production and tourism & $33,1 €$ & $62,0 €$ & 4270 \\
Per capita local spending on city planning and housing & $35,9 €$ & $37,7 €$ & 4270 \\
Per capita local spending on environment and garbage disposal & $145,0 €$ & $87,8 €$ & 4270 \\
Per capita spending on transports & $74,7 €$ & $45,1 €$ & 4270 \\
Local gini coefficient & 0,3 & 0,0 & 3050 \\
Local per-capita taxable income & $16.996,8 €$ & $3.577,1 €$ & 3050 \\
Share of over-65 population & $22,1 \%$ & $3,7 \%$ & 4270 \\
Population density & 205,5 & 293,6 & 4270 \\
Rate of unemployment & $10,2 \%$ & $5,8 \%$ & 4270 \\
Share of population with a tertiary degree & $10,3 \%$ & $3,3 \%$ & 4263 \\
Share of foreign population & $5,5 \%$ & $3,7 \%$ & 4270
\end{tabular}


Table 3. Comparing weighted samples for CATI and VAA survey.

\begin{tabular}{|l|l|l|l|l|l|l|}
\hline Question & $\begin{array}{l}\text { Average } \\
\text { (CATI) }\end{array}$ & $\begin{array}{l}\text { Average } \\
\text { (VAA) }\end{array}$ & $\begin{array}{l}\text { St. Dev. } \\
\text { (CATI) }\end{array}$ & $\begin{array}{l}\text { St. Dev. } \\
\text { (VAA) }\end{array}$ & $\begin{array}{l}\text { Extreme } \\
\text { replies } \\
\text { (1 or 5) CATI }\end{array}$ & $\begin{array}{l}\text { Extreme } \\
\text { replies } \\
\text { (10r 5) VAA }\end{array}$ \\
\hline $\begin{array}{l}\text { Immigration has had a positive impact on the Italian } \\
\text { economy. }\end{array}$ & 2.4 & 2.5 & 1.1. & 1.3 & $24.9 \%$ & $38.2 \%$ \\
\hline $\begin{array}{l}\text { European states should cede more sovereignty to the } \\
\text { European Union. }\end{array}$ & 2.6 & 2.8 & 1.0 & 1.4 & $18.4 \%$ & $38.8 \%$ \\
\hline $\begin{array}{l}\text { The government should take steps to reduce } \\
\text { differences in income levels. }\end{array}$ & 3.8 & 3.8 & 1.0 & 1.2 & $28.2 \%$ & $43.3 \%$ \\
\hline Italy should quit the Euro and return to the Lira. & 2.3 & 2.1 & 1.1 & 1.5 & $31.4 \%$ & $70 . \% 2$ \\
\hline EU membership did to Italy more harm than good. & 3.2 & 3 & 1.1 & 1.4 & $19.9 \%$ & $41.9 \%$ \\
\hline $\begin{array}{l}\text { Italian culture is threatened by the presence of people } \\
\text { who come to live here from other countries. }\end{array}$ & 2.9 & 2.5 & 1.2 & 1.6 & $22.5 \%$ & $61.1 \%$ \\
\hline
\end{tabular}




\begin{tabular}{|c|c|c|c|c|}
\hline Italian wording & Translation & Dimension & Avg. & Std. Dev. \\
\hline L'appartenenza all'Unione Europea ha portato all'Italia più svantaggi che vantaggi & The EU membership has brought to Italy more harm than good & Transnat. & 3,0 & 1,4 \\
\hline La globalizzazione rappresenta un'opportunità per la crescita dell'economia italiana & Globalization represents an opportunity for the Italian economic growth & Transnat. & 3,2 & 1,3 \\
\hline L'Italia dovrebbe investire sulla difesa in maniera autonoma ed uscire dalla NATO & Italy should invest autonomously on defense and leave the NATO & Transnat. & 2,1 & 1,3 \\
\hline $\begin{array}{l}\text { La cultura italiana è minacciata dalla presenza di persone che vengono a vivere qui da } \\
\text { altri Paesi }\end{array}$ & $\begin{array}{l}\text { Italian culture is threatened by the presence of people coming here from } \\
\text { other countries }\end{array}$ & Transnat. & 2,5 & 1,6 \\
\hline Gli stati europei dovrebbero cedere maggiore sovranità all'Unione Europea & European states should cede more sovereignty to the EU & Transnat. & 2,8 & 1,4 \\
\hline L'Italia dovrebbe abbandonare l'Euro e tornare alla Lira & Italy should leave the Euro and go back to the Lira & Transnat. & 2,1 & 1,5 \\
\hline L'immigrazione ha avuto un impatto positivo sull'economia italiana & Immigration had a positive impact on the Italian economy & Transnat. & 2,5 & 1,3 \\
\hline Ė compito dei Paesi occidentali promuovere il rispetto dei diritti umani in tutto il mondo & $\begin{array}{l}\text { It is up to Western Countries to promote the respect of human rights around } \\
\text { the world }\end{array}$ & Transnat. & 3,8 & 1,3 \\
\hline L'età pensionabile è troppo alta e dovrebbe essere abbassata & The legal pension age is too high and should be lowered & Econ & 3,9 & 1,2 \\
\hline Minore è l'intervento dello stato nell'economia, meglio è per l'Italia & The less the state intervenes in the economy, the better is for Italy & Econ & 2,8 & 1,3 \\
\hline $\begin{array}{l}\text { I lavoratori hanno bisogno di sindacati forti per proteggere le loro condizioni di lavoro e } \\
\text { i loro salari }\end{array}$ & $\begin{array}{l}\text { Employees need strong trade unions to protect their working conditions and } \\
\text { wages }\end{array}$ & Econ & 3,5 & 1,4 \\
\hline Le imprese private sono più capaci di creare lavoro che quelle pubbliche & Private enterprises are more capable of creating jobs than public enterprises & Econ & 3,7 & 1,2 \\
\hline L'adozione di misure per ridurre il debito e il deficit italiano non è più rimandabile & $\begin{array}{l}\text { The adoption of measures to reduce the Italian debt and deficit is no longer } \\
\text { avoidable }\end{array}$ & Econ & 3,9 & 1,2 \\
\hline Bisogna semplificare la tassazione con una aliquota singola, uguale per tutti & We need to simplify taxation with a single tax rate for all & Econ & 2,7 & 1,5 \\
\hline II salario minimo legale è una misura prioritaria & The adoption of a legal minimum wage is a priority measure & Econ & 3,8 & 1,2 \\
\hline $\begin{array}{l}\text { II governo dovrebbe prendere provvedimenti per ridurre le differenze nei livelli di } \\
\text { reddito. }\end{array}$ & The government should act to reduce income differences & Econ & 3,8 & 1,2 \\
\hline II consumo di droghe leggere andrebbe fortemente depenalizzato & The consumption of "light" drugs should be depenalized & Cultural & 3,1 & 1,6 \\
\hline Proteggere l'ambiente è una priorità, anche a costo di ridurre la crescita economica & $\begin{array}{l}\text { Protecting the environment is a priority, even at cost of reducing economic } \\
\text { growth }\end{array}$ & Cultural & 3,9 & 1,2 \\
\hline La pedofilia dovrebbe essere punita con il ricorso alla castrazione chimica & Pedophilia should be punished by chemical castration & Cultural & 3,3 & 1,6 \\
\hline il femminicidio deve essere punito come aggravante rispetto a un omicidio & Feminicide should be considered as an aggravation compared to a homicide & Cultural & 3,5 & 1,5 \\
\hline $\begin{array}{l}\text { Le coppie omosessuali dovrebbero avere lo stesso diritto di adottare un figlio delle } \\
\text { coppie eterosessuali }\end{array}$ & $\begin{array}{l}\text { Same-sex couples should have the same right of adopting a child as } \\
\text { heterosexual couples }\end{array}$ & Cultural & 3,1 & 1,7 \\
\hline Bisogna rivedere la legge sull'aborto, per limitare $i$ casi in cui è lecito & We should review the law on abortion, to limit the cases when it is legal & Cultural & 2,2 & 1,4 \\
\hline $\begin{array}{l}\text { Se una persona trova dei ladri in casa ha sempre il diritto di difendersi anche usando } \\
\text { delle armi }\end{array}$ & $\begin{array}{l}\text { If a person finds a burglar in their home they have the right to defend } \\
\text { themselves, even by using guns }\end{array}$ & Cultural & 3,5 & 1,5 \\
\hline $\begin{array}{l}\text { Per combattere il terrorismo in maniera più efficace dobbiamo accettare limiti alla } \\
\text { privacy e alle libertà civili }\end{array}$ & $\begin{array}{l}\text { To fight terrorism efficiently we need to accept limits to our privacy and civic } \\
\text { freedoms }\end{array}$ & Cultural & 2,7 & 1,3 \\
\hline L'ascesa di partiti populisti è un rischio per la democrazia & The rise of populist parties is a threat to democracy & Populism & 3,2 & 1,5 \\
\hline Dovrebbe esserci un limite al numero di volte che una persona può essere eletta & There should be a limit to the number of times someone can be elected & Populism & 3,7 & 1,4 \\
\hline $\begin{array}{l}\text { Se devo scegliere, in un politico preferisco la capacità di rappresentare la gente } \\
\text { rispetto alla competenza }\end{array}$ & $\begin{array}{l}\text { If I must choose, I prefer for a politician to be capable of representing the } \\
\text { people rather than be competent }\end{array}$ & Populism & 2,5 & 1,4 \\
\hline
\end{tabular}


Table 4. VAA items and descriptive statistics 
Table 5: Regression results for hypotheses 1a-1b (all national elections).

\begin{tabular}{|c|c|c|c|c|}
\hline & $\begin{array}{c}\text { (1) } \\
\text { Center-left }\end{array}$ & $\begin{array}{c}\text { (2) } \\
\text { League }\end{array}$ & $\begin{array}{c}\text { (3) } \\
\text { Populist } \\
\text { radical right }\end{array}$ & $\begin{array}{c}\text { (4) } \\
\text { Populist } \\
\text { parties }\end{array}$ \\
\hline $\begin{array}{l}\text { Austerity } \\
\text { dummy=1 \# Per- } \\
\text { capita local current } \\
\text { spending }\end{array}$ & $\begin{array}{l}0.00^{* * *} \\
(0.00)\end{array}$ & $\begin{array}{l}-0.00 \\
(0.00)\end{array}$ & $\begin{array}{c}0.00 \\
(0.00)\end{array}$ & $\begin{array}{l}-0.00 \\
(0.00)\end{array}$ \\
\hline $\begin{array}{l}\text { Austerity } \\
\text { dummy=1 \# Share } \\
\text { of } 65+\end{array}$ & $\begin{array}{l}-0.06 \\
(0.06)\end{array}$ & $\begin{array}{c}0.18^{* * *} \\
(0.04)\end{array}$ & $\begin{array}{l}0.20^{* * *} \\
(0.05)\end{array}$ & $\begin{array}{l}-0.00 \\
(0.08)\end{array}$ \\
\hline $\begin{array}{l}\text { Austerity } \\
\text { dummy=1 \# } \\
\text { Population density }\end{array}$ & $\begin{array}{c}0.00 \\
(0.00)\end{array}$ & $\begin{array}{c}-0.00^{* * *} \\
(0.00)\end{array}$ & $\begin{array}{l}-0.00^{*} \\
(0.00)\end{array}$ & $\begin{array}{c}0.00 \\
(0.00)\end{array}$ \\
\hline $\begin{array}{l}\text { Austerity } \\
\text { dummy }=1 \# \\
\text { Unemployment rate }\end{array}$ & $\begin{array}{c}-0.33^{* * *} \\
(0.09)\end{array}$ & $\begin{array}{c}0.14^{* * *} \\
(0.04)\end{array}$ & $\begin{array}{l}0.15^{*} \\
(0.06)\end{array}$ & $\begin{array}{l}0.39^{* * *} \\
(0.09)\end{array}$ \\
\hline $\begin{array}{l}\text { Austerity } \\
\text { dummy=1 \# Share } \\
\text { of pop. with tertiary } \\
\text { degree }\end{array}$ & $\begin{array}{c}-0.54^{* * *} \\
(0.08)\end{array}$ & $\begin{array}{c}0.43^{* * *} \\
(0.05)\end{array}$ & $\begin{array}{l}0.36^{* * * *} \\
(0.06)\end{array}$ & $\begin{array}{l}0.53^{* * * *} \\
(0.10)\end{array}$ \\
\hline $\begin{array}{l}\text { Austerity } \\
\text { dummy=1 \# Share } \\
\text { of foreign pop. }\end{array}$ & $\begin{array}{c}0.02 \\
(0.07)\end{array}$ & $\begin{array}{c}0.01 \\
(0.05)\end{array}$ & $\begin{array}{c}0.04 \\
(0.07)\end{array}$ & $\begin{array}{c}0.00 \\
(0.11)\end{array}$ \\
\hline $\begin{array}{l}\text { Per-capita local } \\
\text { current spending }\end{array}$ & $\begin{array}{l}-0.00^{* *} \\
(0.00)\end{array}$ & $\begin{array}{l}-0.00 \\
(0.00)\end{array}$ & $\begin{array}{l}-0.00 \\
(0.00)\end{array}$ & $\begin{array}{c}0.00 \\
(0.00)\end{array}$ \\
\hline Share of $65+$ & $\begin{array}{c}0.12 \\
(0.17)\end{array}$ & $\begin{array}{c}0.03 \\
(0.13)\end{array}$ & $\begin{array}{c}0.02 \\
(0.17)\end{array}$ & $\begin{array}{l}0.83^{* * *} \\
(0.22)\end{array}$ \\
\hline Population density & $\begin{array}{l}0.02^{* *} \\
(0.01)\end{array}$ & $\begin{array}{c}0.00 \\
(0.00)\end{array}$ & $\begin{array}{c}0.00 \\
(0.00)\end{array}$ & $\begin{array}{l}-0.01 \\
(0.01)\end{array}$ \\
\hline Unemployment rate & $\begin{array}{c}0.23 \\
(0.16)\end{array}$ & $\begin{array}{l}-0.04 \\
(0.09)\end{array}$ & $\begin{array}{l}-0.03 \\
(0.11)\end{array}$ & $\begin{array}{l}-0.27 \\
(0.14)\end{array}$ \\
\hline $\begin{array}{l}\text { Share of pop. with } \\
\text { tertiary degree } \\
\text { Share of foreign } \\
\text { pop. }\end{array}$ & $\begin{array}{l}3.56^{* * *} \\
(0.43) \\
-0.19 \\
(0.13) \\
\end{array}$ & $\begin{array}{c}-4.28^{* * * *} \\
(0.45) \\
0.41^{* * *} \\
(0.12) \\
\end{array}$ & $\begin{array}{c}-4.11^{* * *} \\
(0.49) \\
0.48^{* * *} \\
(0.14) \\
\end{array}$ & $\begin{array}{c}-4.40^{* * *} \\
(0.52) \\
0.76^{* * *} \\
(0.17) \\
\end{array}$ \\
\hline $\begin{array}{l}\mathrm{N} \\
\mathrm{r} 2\end{array}$ & $\begin{array}{l}3972 \\
0.94\end{array}$ & $\begin{array}{l}3972 \\
0.98\end{array}$ & $\begin{array}{l}3972 \\
0.98\end{array}$ & $\begin{array}{l}3972 \\
0.98\end{array}$ \\
\hline
\end{tabular}

Clustered standard errors in parenthesis

$* \mathrm{p}<0.05, * * \mathrm{p}<0.01, * * * \mathrm{p}<0.001$ 
Table 6: Regression results for hypotheses 1a-1b (parliamentary elections).

\begin{tabular}{|c|c|c|c|c|}
\hline & $\begin{array}{c}\text { (1) } \\
\text { Center-left }\end{array}$ & $\begin{array}{c}(2) \\
\text { League }\end{array}$ & $\begin{array}{c}\text { (3) } \\
\text { Populist } \\
\text { radical right }\end{array}$ & $\begin{array}{c}\text { (4) } \\
\text { Populist } \\
\text { parties }\end{array}$ \\
\hline $\begin{array}{l}\text { Austerity } \\
\text { dummy=1 \# Per- } \\
\text { capita local current } \\
\text { spending }\end{array}$ & $\begin{array}{c}0.00^{* * *} \\
(0.00)\end{array}$ & $\begin{array}{l}-0.00 \\
(0.00)\end{array}$ & $\begin{array}{c}0.00 \\
(0.00)\end{array}$ & $\begin{array}{l}-0.00^{*} \\
(0.00)\end{array}$ \\
\hline $\begin{array}{l}\text { Austerity } \\
\text { dummy=1 \# Share } \\
\text { of } 65+\end{array}$ & $\begin{array}{l}-0.04 \\
(0.07)\end{array}$ & $\begin{array}{c}0.18^{* * *} \\
(0.04)\end{array}$ & $\begin{array}{l}0.22^{* * *} \\
(0.05)\end{array}$ & $\begin{array}{c}0.05 \\
(0.09)\end{array}$ \\
\hline $\begin{array}{l}\text { Austerity } \\
\text { dummy } 1 \# \\
\text { Population density }\end{array}$ & $\begin{array}{l}-0.00 \\
(0.00)\end{array}$ & $\begin{array}{l}-0.00 \\
(0.00)\end{array}$ & $\begin{array}{l}-0.00 \\
(0.00)\end{array}$ & $\begin{array}{c}0.00 \\
(0.00)\end{array}$ \\
\hline $\begin{array}{l}\text { Austerity } \\
\text { dummy }=1 \# \\
\text { Unemployment rate }\end{array}$ & $\begin{array}{l}-0.25^{* *} \\
(0.09)\end{array}$ & $\begin{array}{c}0.11^{*} \\
(0.04)\end{array}$ & $\begin{array}{c}0.09 \\
(0.05)\end{array}$ & $\begin{array}{l}0.32^{* *} \\
(0.10)\end{array}$ \\
\hline $\begin{array}{l}\text { Austerity } \\
\text { dummy }=1 \text { \# Share } \\
\text { of pop. with tertiary } \\
\text { degree }\end{array}$ & $\begin{array}{c}-0.34^{* * *} \\
(0.08)\end{array}$ & $\begin{array}{c}0.32^{* * *} \\
(0.05)\end{array}$ & $\begin{array}{c}0.25^{* * *} \\
(0.06)\end{array}$ & $\begin{array}{c}0.43^{* * *} \\
(0.12)\end{array}$ \\
\hline $\begin{array}{l}\text { Austerity } \\
\text { dummy=1 \# Share } \\
\text { of foreign pop. }\end{array}$ & $\begin{array}{c}0.05 \\
(0.07)\end{array}$ & $\begin{array}{c}0.05 \\
(0.06)\end{array}$ & $\begin{array}{c}0.06 \\
(0.07)\end{array}$ & $\begin{array}{c}0.04 \\
(0.12)\end{array}$ \\
\hline $\begin{array}{l}\text { Per-capita local } \\
\text { current spending }\end{array}$ & $\begin{array}{l}-0.00 \\
(0.00)\end{array}$ & $\begin{array}{l}-0.00 \\
(0.00)\end{array}$ & $\begin{array}{l}-0.00 \\
(0.00)\end{array}$ & $\begin{array}{l}-0.00 \\
(0.00)\end{array}$ \\
\hline Share of $65+$ & $\begin{array}{l}-0.04 \\
(0.25)\end{array}$ & $\begin{array}{c}0.08 \\
(0.12)\end{array}$ & $\begin{array}{c}0.04 \\
(0.15)\end{array}$ & $\begin{array}{l}0.97^{* * *} \\
(0.26)\end{array}$ \\
\hline Population density & $\begin{array}{l}0.03^{* * *} \\
(0.00)\end{array}$ & $\begin{array}{l}-0.01 \\
(0.01)\end{array}$ & $\begin{array}{c}0.00 \\
(0.01)\end{array}$ & $\begin{array}{l}-0.01 \\
(0.01)\end{array}$ \\
\hline Unemployment rate & $\begin{array}{c}0.09 \\
(0.19)\end{array}$ & $\begin{array}{l}-0.03 \\
(0.07)\end{array}$ & $\begin{array}{l}-0.03 \\
(0.09)\end{array}$ & $\begin{array}{l}-0.27 \\
(0.16)\end{array}$ \\
\hline $\begin{array}{l}\text { Share of pop. with } \\
\text { tertiary degree } \\
\text { Share of foreign } \\
\text { pop. }\end{array}$ & $\begin{array}{l}2.53^{* * *} \\
(0.58) \\
-0.30 \\
(0.20)\end{array}$ & $\begin{array}{c}-2.67^{* * *} \\
(0.44) \\
0.27^{*} \\
(0.11)\end{array}$ & $\begin{array}{c}-2.50^{* * *} \\
(0.50) \\
0.27^{*} \\
(0.12)\end{array}$ & $\begin{array}{c}-2.74^{* * *} \\
(0.63) \\
0.62^{* *} \\
(0.20)\end{array}$ \\
\hline $\begin{array}{l}\mathrm{N} \\
\mathrm{r} 2\end{array}$ & $\begin{array}{l}2271 \\
0.96\end{array}$ & $\begin{array}{r}2271 \\
0.98\end{array}$ & $\begin{array}{l}2271 \\
0.98\end{array}$ & $\begin{array}{r}2271 \\
0.99\end{array}$ \\
\hline
\end{tabular}

Clustered standard errors in parenthesis

$* \mathrm{p}<0.05, * * \mathrm{p}<0.01, * * * \mathrm{p}<0.001$ 
Table 7: Regression results for hypotheses 2a-2b (all national elections).

\begin{tabular}{|c|c|c|c|c|}
\hline & $\begin{array}{c}\text { (1) } \\
\text { Center-left }\end{array}$ & $\begin{array}{c}\text { (2) } \\
\text { League }\end{array}$ & $\begin{array}{c}\text { (3) } \\
\text { Populist } \\
\text { radical right }\end{array}$ & $\begin{array}{c}\text { (4) } \\
\text { Populist } \\
\text { parties }\end{array}$ \\
\hline $\begin{array}{l}\text { Austerity } \\
\text { dummy=1 \# Per- } \\
\text { capita local social } \\
\text { spending }\end{array}$ & $\begin{array}{l}0.00^{*} \\
(0.00)\end{array}$ & $\begin{array}{c}-0.00^{* *} \\
(0.00)\end{array}$ & $\begin{array}{l}-0.00^{*} \\
(0.00)\end{array}$ & $\begin{array}{l}-0.00 \\
(0.00)\end{array}$ \\
\hline $\begin{array}{l}\text { Austerity } \\
\text { dummy=1 \# Share } \\
\text { of } 65+\end{array}$ & $\begin{array}{l}-0.00 \\
(0.06)\end{array}$ & $\begin{array}{l}0.21^{* * *} \\
(0.04)\end{array}$ & $\begin{array}{l}0.24^{* * *} \\
(0.05)\end{array}$ & $\begin{array}{l}-0.00 \\
(0.08)\end{array}$ \\
\hline $\begin{array}{l}\text { Austerity } \\
\text { dummy=1 \# } \\
\text { Population density }\end{array}$ & $\begin{array}{c}0.00 \\
(0.00)\end{array}$ & $\begin{array}{c}-0.00^{* *} \\
(0.00)\end{array}$ & $\begin{array}{l}-0.00^{*} \\
(0.00)\end{array}$ & $\begin{array}{c}0.00 \\
(0.00)\end{array}$ \\
\hline $\begin{array}{l}\text { Austerity } \\
\text { dummy }=1 \# \\
\text { Unemployment rate }\end{array}$ & $\begin{array}{c}-0.36^{* * *} \\
(0.09)\end{array}$ & $\begin{array}{l}0.13^{* *} \\
(0.04)\end{array}$ & $\begin{array}{c}0.13^{*} \\
(0.06)\end{array}$ & $\begin{array}{l}0.40^{* * *} \\
(0.09)\end{array}$ \\
\hline $\begin{array}{l}\text { Austerity } \\
\text { dummy=1 \# Share } \\
\text { of pop. with tertiary } \\
\text { degree }\end{array}$ & $\begin{array}{c}-0.56^{* * *} \\
(0.08)\end{array}$ & $\begin{array}{c}0.47^{* * *} \\
(0.05)\end{array}$ & $\begin{array}{l}0.40^{* * * *} \\
(0.07)\end{array}$ & $\begin{array}{l}0.57^{* * * *} \\
(0.10)\end{array}$ \\
\hline $\begin{array}{l}\text { Austerity } \\
\text { dummy=1 \# Share } \\
\text { of foreign pop. }\end{array}$ & $\begin{array}{c}0.03 \\
(0.07)\end{array}$ & $\begin{array}{l}-0.00 \\
(0.05)\end{array}$ & $\begin{array}{c}0.03 \\
(0.07)\end{array}$ & $\begin{array}{l}-0.01 \\
(0.11)\end{array}$ \\
\hline $\begin{array}{l}\text { Per-capita local } \\
\text { social spending }\end{array}$ & $\begin{array}{c}0.00 \\
(0.00)\end{array}$ & $\begin{array}{l}-0.00 \\
(0.00)\end{array}$ & $\begin{array}{l}-0.00 \\
(0.00)\end{array}$ & $\begin{array}{l}-0.00 \\
(0.00)\end{array}$ \\
\hline Share of $65+$ & $\begin{array}{c}0.16 \\
(0.18)\end{array}$ & $\begin{array}{c}0.01 \\
(0.13)\end{array}$ & $\begin{array}{c}0.02 \\
(0.18)\end{array}$ & $\begin{array}{l}0.81^{* * *} \\
(0.22)\end{array}$ \\
\hline Population density & $\begin{array}{l}0.02^{* *} \\
(0.01)\end{array}$ & $\begin{array}{c}0.00 \\
(0.00)\end{array}$ & $\begin{array}{c}0.00 \\
(0.00)\end{array}$ & $\begin{array}{l}-0.01 \\
(0.01)\end{array}$ \\
\hline Unemployment rate & $\begin{array}{c}0.23 \\
(0.16)\end{array}$ & $\begin{array}{l}-0.03 \\
(0.09)\end{array}$ & $\begin{array}{l}-0.02 \\
(0.11)\end{array}$ & $\begin{array}{l}-0.27 \\
(0.15)\end{array}$ \\
\hline $\begin{array}{l}\text { Share of pop. with } \\
\text { tertiary degree } \\
\text { Share of foreign } \\
\text { pop. }\end{array}$ & $\begin{array}{l}3.51^{* * *} \\
(0.43) \\
-0.15 \\
(0.13)\end{array}$ & $\begin{array}{c}-4.35^{* * *} \\
(0.45) \\
0.40^{* * *} \\
(0.11)\end{array}$ & $\begin{array}{c}-4.21^{* * *} \\
(0.50) \\
0.48^{* * *} \\
(0.14)\end{array}$ & $\begin{array}{c}-4.44^{* * *} \\
(0.52) \\
0.75^{* * *} \\
(0.17)\end{array}$ \\
\hline $\begin{array}{l}\mathrm{N} \\
\mathrm{r} 2\end{array}$ & $\begin{array}{l}3972 \\
0.94\end{array}$ & $\begin{array}{l}3972 \\
0.98\end{array}$ & $\begin{array}{l}3972 \\
0.98\end{array}$ & $\begin{array}{l}3972 \\
0.98\end{array}$ \\
\hline
\end{tabular}

Clustered standard errors in parenthesis

$* \mathrm{p}<0.05, * * \mathrm{p}<0.01, * * * \mathrm{p}<0.001$ 
Table 8: Regression results for hypotheses $2 \mathrm{a}-2 \mathrm{~b}$ (parliamentary elections).

\begin{tabular}{|c|c|c|c|c|}
\hline & $\begin{array}{c}\text { (1) } \\
\text { Center-left }\end{array}$ & $\begin{array}{c}(2) \\
\text { League }\end{array}$ & $\begin{array}{c}\text { (3) } \\
\text { Populist } \\
\text { radical right }\end{array}$ & $\begin{array}{c}\text { (4) } \\
\text { Populist } \\
\text { parties }\end{array}$ \\
\hline $\begin{array}{l}\text { Austerity } \\
\text { dummy=1 \# Per- } \\
\text { capita local current } \\
\text { spending }\end{array}$ & $\begin{array}{l}0.00^{* * *} \\
(0.00)\end{array}$ & $\begin{array}{c}-0.00 \\
(0.00)\end{array}$ & $\begin{array}{c}0.00 \\
(0.00)\end{array}$ & $\begin{array}{l}-0.00^{*} \\
(0.00)\end{array}$ \\
\hline $\begin{array}{l}\text { Austerity } \\
\text { dummy=1 \# Share } \\
\text { of } 65+\end{array}$ & $\begin{array}{l}-0.04 \\
(0.07)\end{array}$ & $\begin{array}{c}0.18^{* * *} \\
(0.04)\end{array}$ & $\begin{array}{c}0.22^{* * *} \\
(0.05)\end{array}$ & $\begin{array}{c}0.05 \\
(0.09)\end{array}$ \\
\hline $\begin{array}{l}\text { Austerity } \\
\text { dummy=1 \# } \\
\text { Population density }\end{array}$ & $\begin{array}{l}-0.00 \\
(0.00)\end{array}$ & $\begin{array}{l}-0.00 \\
(0.00)\end{array}$ & $\begin{array}{l}-0.00 \\
(0.00)\end{array}$ & $\begin{array}{c}0.00 \\
(0.00)\end{array}$ \\
\hline $\begin{array}{l}\text { Austerity } \\
\text { dummy }=1 \# \\
\text { Unemployment rate }\end{array}$ & $\begin{array}{l}-0.25^{* *} \\
(0.09)\end{array}$ & $\begin{array}{l}0.11^{*} \\
(0.04)\end{array}$ & $\begin{array}{c}0.09 \\
(0.05)\end{array}$ & $\begin{array}{l}0.32^{* *} \\
(0.10)\end{array}$ \\
\hline $\begin{array}{l}\text { Austerity } \\
\text { dummy=1 \# Share } \\
\text { of pop. with tertiary } \\
\text { degree }\end{array}$ & $\begin{array}{c}-0.34^{* * *} \\
(0.08)\end{array}$ & $\begin{array}{c}0.32^{* * *} \\
(0.05)\end{array}$ & $\begin{array}{c}0.25^{\text {**** }} \\
(0.06)\end{array}$ & $\begin{array}{c}0.43^{* * *} \\
(0.12)\end{array}$ \\
\hline $\begin{array}{l}\text { Austerity } \\
\text { dummy=1 \# Share } \\
\text { of foreign pop. }\end{array}$ & $\begin{array}{c}0.05 \\
(0.07)\end{array}$ & $\begin{array}{c}0.05 \\
(0.06)\end{array}$ & $\begin{array}{c}0.06 \\
(0.07)\end{array}$ & $\begin{array}{c}0.04 \\
(0.12)\end{array}$ \\
\hline $\begin{array}{l}\text { Per-capita local } \\
\text { current spending }\end{array}$ & $\begin{array}{l}-0.00 \\
(0.00)\end{array}$ & $\begin{array}{l}-0.00 \\
(0.00)\end{array}$ & $\begin{array}{l}-0.00 \\
(0.00)\end{array}$ & $\begin{array}{l}-0.00 \\
(0.00)\end{array}$ \\
\hline Share of $65+$ & $\begin{array}{l}-0.04 \\
(0.25)\end{array}$ & $\begin{array}{c}0.08 \\
(0.12)\end{array}$ & $\begin{array}{c}0.04 \\
(0.15)\end{array}$ & $\begin{array}{l}0.97^{* * * *} \\
(0.26)\end{array}$ \\
\hline Population density & $\begin{array}{l}0.03^{* * *} \\
(0.00)\end{array}$ & $\begin{array}{l}-0.01 \\
(0.01)\end{array}$ & $\begin{array}{c}0.00 \\
(0.01)\end{array}$ & $\begin{array}{l}-0.01 \\
(0.01)\end{array}$ \\
\hline Unemployment rate & $\begin{array}{c}0.09 \\
(0.19)\end{array}$ & $\begin{array}{l}-0.03 \\
(0.07)\end{array}$ & $\begin{array}{l}-0.03 \\
(0.09)\end{array}$ & $\begin{array}{l}-0.27 \\
(0.16)\end{array}$ \\
\hline $\begin{array}{l}\text { Share of pop. with } \\
\text { tertiary degree } \\
\text { Share of foreign } \\
\text { pop. }\end{array}$ & $\begin{array}{l}2.53^{* * * *} \\
(0.58) \\
-0.30 \\
(0.20)\end{array}$ & $\begin{array}{c}-2.67^{* * *} \\
(0.44) \\
0.27^{*} \\
(0.11)\end{array}$ & $\begin{array}{c}-2.50^{* * *} \\
(0.50) \\
0.27^{*} \\
(0.12)\end{array}$ & $\begin{array}{c}-2.74^{* * *} \\
(0.63) \\
0.62^{* *} \\
(0.20)\end{array}$ \\
\hline $\begin{array}{l}\mathrm{N} \\
\mathrm{r} 2\end{array}$ & $\begin{array}{r}2271 \\
0.96\end{array}$ & $\begin{array}{r}2271 \\
0.98\end{array}$ & $\begin{array}{l}2271 \\
0.98\end{array}$ & $\begin{array}{l}2271 \\
0.99\end{array}$ \\
\hline
\end{tabular}

Clustered standard errors in parenthesis

$* \mathrm{p}<0.05, * * \mathrm{p}<0.01, * * * \mathrm{p}<0.001$ 
Table 9: Regression results for hypothesis 3 (all national elections).

\begin{tabular}{|c|c|c|c|c|}
\hline & $\begin{array}{c}\text { (1) } \\
\text { Center-left }\end{array}$ & $\begin{array}{c}(2) \\
\text { League }\end{array}$ & $\begin{array}{c}\text { (3) } \\
\text { Populist } \\
\text { radical right }\end{array}$ & $\begin{array}{c}\text { (4) } \\
\text { Populist } \\
\text { parties }\end{array}$ \\
\hline $\begin{array}{l}\text { Austerity } \\
\text { dummy=1 \# } \\
\text { Education and } \\
\text { family }\end{array}$ & $\begin{array}{l}-0.00 \\
(0.00)\end{array}$ & $\begin{array}{l}-0.00^{*} \\
(0.00)\end{array}$ & $\begin{array}{c}-0.00^{* *} \\
(0.00)\end{array}$ & $\begin{array}{l}-0.00 \\
(0.00)\end{array}$ \\
\hline $\begin{array}{l}\text { Austerity } \\
\text { dummy=1 \# Law } \\
\text { and order }\end{array}$ & $\begin{array}{c}0.01 \\
(0.01)\end{array}$ & $\begin{array}{l}0.02^{* *} \\
(0.00)\end{array}$ & $\begin{array}{l}0.02^{* *} \\
(0.01)\end{array}$ & $\begin{array}{l}0.03^{*} \\
(0.01)\end{array}$ \\
\hline $\begin{array}{l}\text { Austerity } \\
\text { dummy=1 \# } \\
\text { Industry, tourism } \\
\text { and agriculture }\end{array}$ & $\begin{array}{l}-0.00 \\
(0.00)\end{array}$ & $\begin{array}{c}0.00 \\
(0.00)\end{array}$ & $\begin{array}{l}0.00^{*} \\
(0.00)\end{array}$ & $\begin{array}{c}0.00 \\
(0.00)\end{array}$ \\
\hline $\begin{array}{l}\text { Austerity } \\
\text { dummy=1 \# City } \\
\text { planning and } \\
\text { housing }\end{array}$ & $\begin{array}{c}0.01 \\
(0.01)\end{array}$ & $\begin{array}{c}-0.01^{* * *} \\
(0.00)\end{array}$ & $\begin{array}{l}-0.00 \\
(0.00)\end{array}$ & $\begin{array}{l}-0.01 \\
(0.01)\end{array}$ \\
\hline $\begin{array}{l}\text { Austerity } \\
\text { dummy }=1 \# \text { other }\end{array}$ & $\begin{array}{l}0.00^{* *} \\
(0.00)\end{array}$ & $\begin{array}{c}0.00 \\
(0.00)\end{array}$ & $\begin{array}{l}-0.00 \\
(0.00)\end{array}$ & $\begin{array}{l}-0.00^{*} \\
(0.00)\end{array}$ \\
\hline $\begin{array}{l}\text { Austerity } \\
\text { dummy=1 \# Share } \\
\text { of } 65+\end{array}$ & $\begin{array}{c}0.04 \\
(0.06)\end{array}$ & $\begin{array}{l}0.16^{* * *} \\
(0.03)\end{array}$ & $\begin{array}{l}0.20^{* * *} \\
(0.04)\end{array}$ & $\begin{array}{l}-0.01 \\
(0.08)\end{array}$ \\
\hline $\begin{array}{l}\text { Austerity } \\
\text { dummy }=1 \text { \# } \\
\text { Population density }\end{array}$ & $\begin{array}{l}-0.00 \\
(0.00)\end{array}$ & $\begin{array}{l}-0.00 \\
(0.00)\end{array}$ & $\begin{array}{l}-0.00 \\
(0.00)\end{array}$ & $\begin{array}{c}0.00 \\
(0.00)\end{array}$ \\
\hline $\begin{array}{l}\text { Austerity } \\
\text { dummy }=1 \# \\
\text { Unemployment rate }\end{array}$ & $\begin{array}{l}-0.27^{* *} \\
(0.09)\end{array}$ & $\begin{array}{l}0.10^{* *} \\
(0.03)\end{array}$ & $\begin{array}{l}0.10^{*} \\
(0.04)\end{array}$ & $\begin{array}{l}0.32^{* * *} \\
(0.09)\end{array}$ \\
\hline $\begin{array}{l}\text { Austerity } \\
\text { dummy=1 \# Share } \\
\text { of pop. with tertiary } \\
\text { degree }\end{array}$ & $\begin{array}{c}-0.50^{* * *} \\
(0.08)\end{array}$ & $\begin{array}{l}0.31^{* * *} \\
(0.05)\end{array}$ & $\begin{array}{l}0.28^{* * *} \\
(0.06)\end{array}$ & $\begin{array}{l}0.40^{* * *} \\
(0.11)\end{array}$ \\
\hline $\begin{array}{l}\text { Austerity } \\
\text { dummy=1 \# Share } \\
\text { of foreign pop. }\end{array}$ & $\begin{array}{c}0.01 \\
(0.06)\end{array}$ & $\begin{array}{l}-0.03 \\
(0.04)\end{array}$ & $\begin{array}{l}-0.00 \\
(0.05)\end{array}$ & $\begin{array}{c}0.01 \\
(0.11)\end{array}$ \\
\hline other & $\begin{array}{l}-0.00 \\
(0.00)\end{array}$ & $\begin{array}{l}-0.00 \\
(0.00)\end{array}$ & $\begin{array}{l}-0.00 \\
(0.00)\end{array}$ & $\begin{array}{c}0.00 \\
(0.00)\end{array}$ \\
\hline $\begin{array}{l}\text { Education and } \\
\text { family }\end{array}$ & $\begin{array}{c}0.00 \\
(0.00)\end{array}$ & $\begin{array}{l}0.00 \\
(0.00)\end{array}$ & $\begin{array}{c}0.00 \\
(0.00)\end{array}$ & $\begin{array}{l}-0.00 \\
(0.00)\end{array}$ \\
\hline Law and order & $\begin{array}{l}-0.03^{*} \\
(0.01)\end{array}$ & $\begin{array}{l}-0.00 \\
(0.01)\end{array}$ & $\begin{array}{l}-0.01 \\
(0.01)\end{array}$ & $\begin{array}{c}0.00 \\
(0.01)\end{array}$ \\
\hline $\begin{array}{l}\text { Industry, tourism } \\
\text { and agriculture }\end{array}$ & $\begin{array}{c}0.00 \\
(0.00)\end{array}$ & $\begin{array}{l}-0.00 \\
(0.00)\end{array}$ & $\begin{array}{c}0.00 \\
(0.00)\end{array}$ & $\begin{array}{l}-0.01^{*} \\
(0.00)\end{array}$ \\
\hline $\begin{array}{l}\text { City planning and } \\
\text { housing }\end{array}$ & $\begin{array}{l}-0.01 \\
(0.01)\end{array}$ & $\begin{array}{l}0.00 \\
(0.00)\end{array}$ & $\begin{array}{c}0.00 \\
(0.00)\end{array}$ & $\begin{array}{c}0.01 \\
(0.01)\end{array}$ \\
\hline Share of $65+$ & $\begin{array}{l}-0.12 \\
(0.18)\end{array}$ & $\begin{array}{l}-0.07 \\
(0.10)\end{array}$ & $\begin{array}{l}-0.14 \\
(0.13)\end{array}$ & $\begin{array}{l}0.96^{* * *} \\
(0.26)\end{array}$ \\
\hline Population density & $\begin{array}{l}0.03^{* * *} \\
(0.01)\end{array}$ & $\begin{array}{l}-0.01 \\
(0.00)\end{array}$ & $\begin{array}{c}0.00 \\
(0.01)\end{array}$ & $\begin{array}{l}-0.02 \\
(0.01)\end{array}$ \\
\hline
\end{tabular}




\begin{tabular}{lcccc} 
Unemployment rate & 0.07 & -0.06 & -0.10 & -0.25 \\
& $(0.15)$ & $(0.06)$ & $(0.08)$ & $(0.15)$ \\
Share of pop. with & $3.11^{* * *}$ & $-2.55^{* * *}$ & $-2.57^{* * *}$ & $-2.78^{* * *}$ \\
tertiary degree & $(0.48)$ & $(0.40)$ & $(0.46)$ & $(0.59)$ \\
Share of foreign & $-0.28^{*}$ & $0.27^{* *}$ & $0.32^{* *}$ & $0.68^{* * *}$ \\
pop. & $(0.14)$ & $(0.09)$ & $(0.11)$ & $(0.17)$ \\
\hline $\mathrm{N}$ & 3427 & 3427 & 3427 & 3427 \\
r2 & 0.94 & 0.98 & 0.98 & 0.98 \\
\hline
\end{tabular}

Clustered standard errors in parenthesis

$* \mathrm{p}<0.05, * * \mathrm{p}<0.01, * * * \mathrm{p}<0.001$ 
Table 10: Regression results for hypothesis 3 (parliamentary elections).

\begin{tabular}{|c|c|c|c|c|}
\hline & $\begin{array}{c}\text { (1) } \\
\text { Center-left }\end{array}$ & $\begin{array}{c}\text { (2) } \\
\text { League }\end{array}$ & $\begin{array}{c}\text { (3) } \\
\text { Populist } \\
\text { radical right }\end{array}$ & $\begin{array}{c}\text { (4) } \\
\text { Populist } \\
\text { parties }\end{array}$ \\
\hline $\begin{array}{l}\text { Austerity } \\
\text { dummy=1 \# } \\
\text { Education and } \\
\text { family }\end{array}$ & $\begin{array}{l}-0.01^{*} \\
(0.00)\end{array}$ & $\begin{array}{c}-0.00^{* *} \\
(0.00)\end{array}$ & $\begin{array}{c}-0.01^{* *} \\
(0.00)\end{array}$ & $\begin{array}{l}-0.00 \\
(0.00)\end{array}$ \\
\hline $\begin{array}{l}\text { Austerity } \\
\text { dummy=1 \# Law } \\
\text { and order }\end{array}$ & $\begin{array}{l}0.02^{*} \\
(0.01)\end{array}$ & $\begin{array}{l}0.02^{*} \\
(0.01)\end{array}$ & $\begin{array}{l}0.02^{* *} \\
(0.01)\end{array}$ & $\begin{array}{l}0.03^{*} \\
(0.02)\end{array}$ \\
\hline $\begin{array}{l}\text { Austerity } \\
\text { dummy=1 \# } \\
\text { Industry, tourism } \\
\text { and agriculture }\end{array}$ & $\begin{array}{c}0.00 \\
(0.00)\end{array}$ & $\begin{array}{c}0.00 \\
(0.00)\end{array}$ & $\begin{array}{c}0.00 \\
(0.00)\end{array}$ & $\begin{array}{c}0.00 \\
(0.00)\end{array}$ \\
\hline $\begin{array}{l}\text { Austerity } \\
\text { dummy=1 \# other } \\
\text { Austerity } \\
\text { dummy=1 \# City } \\
\text { planning and } \\
\text { housing }\end{array}$ & $\begin{array}{l}0.00^{* *} \\
(0.00) \\
0.01^{*} \\
(0.01)\end{array}$ & $\begin{array}{c}0.00 \\
(0.00) \\
-0.01^{* *} \\
(0.00)\end{array}$ & $\begin{array}{c}0.00 \\
(0.00) \\
-0.00 \\
(0.00)\end{array}$ & $\begin{array}{l}-0.00 \\
(0.00) \\
-0.01 \\
(0.01)\end{array}$ \\
\hline $\begin{array}{l}\text { Austerity } \\
\text { dummy=1 \# } \\
\text { Transports }\end{array}$ & $\begin{array}{l}-0.00 \\
(0.01)\end{array}$ & $\begin{array}{l}-0.00 \\
(0.00)\end{array}$ & $\begin{array}{l}-0.00 \\
(0.00)\end{array}$ & $\begin{array}{l}-0.01 \\
(0.01)\end{array}$ \\
\hline $\begin{array}{l}\text { Austerity } \\
\text { dummy=1 \# Share } \\
\text { of } 65+\end{array}$ & $\begin{array}{l}-0.03 \\
(0.06)\end{array}$ & $\begin{array}{l}0.19^{* * *} \\
(0.04)\end{array}$ & $\begin{array}{c}0.23^{* * *} \\
(0.05)\end{array}$ & $\begin{array}{c}0.06 \\
(0.09)\end{array}$ \\
\hline $\begin{array}{l}\text { Austerity } \\
\text { dummy }=1 \text { \# } \\
\text { Population density }\end{array}$ & $\begin{array}{l}-0.00 \\
(0.00)\end{array}$ & $\begin{array}{l}-0.00 \\
(0.00)\end{array}$ & $\begin{array}{l}-0.00 \\
(0.00)\end{array}$ & $\begin{array}{c}0.00 \\
(0.00)\end{array}$ \\
\hline $\begin{array}{l}\text { Austerity } \\
\text { dummy }=1 \# \\
\text { Unemployment rate }\end{array}$ & $\begin{array}{l}-0.27^{* *} \\
(0.09)\end{array}$ & $\begin{array}{l}0.10^{*} \\
(0.04)\end{array}$ & $\begin{array}{c}0.07 \\
(0.05)\end{array}$ & $\begin{array}{l}0.31^{* *} \\
(0.10)\end{array}$ \\
\hline $\begin{array}{l}\text { Austerity } \\
\text { dummy=1 \# Share } \\
\text { of pop. with tertiary } \\
\text { degree }\end{array}$ & $\begin{array}{c}-0.30^{* * *} \\
(0.09)\end{array}$ & $\begin{array}{l}0.33^{* * *} \\
(0.05)\end{array}$ & $\begin{array}{l}0.26^{* * *} \\
(0.07)\end{array}$ & $\begin{array}{l}0.37^{* *} \\
(0.12)\end{array}$ \\
\hline $\begin{array}{l}\text { Austerity } \\
\text { dummy=1 \# Share } \\
\text { of foreign pop. }\end{array}$ & $\begin{array}{c}0.03 \\
(0.07)\end{array}$ & $\begin{array}{l}0.05 \\
(0.05)\end{array}$ & $\begin{array}{c}0.06 \\
(0.06)\end{array}$ & $\begin{array}{c}0.04 \\
(0.12)\end{array}$ \\
\hline other & $\begin{array}{l}-0.00 \\
(0.00)\end{array}$ & $\begin{array}{l}-0.00 \\
(0.00)\end{array}$ & $\begin{array}{l}-0.00 \\
(0.00)\end{array}$ & $\begin{array}{c}0.00 \\
(0.00)\end{array}$ \\
\hline $\begin{array}{l}\text { Education and } \\
\text { family }\end{array}$ & $\begin{array}{c}0.01 \\
(0.00)\end{array}$ & $\begin{array}{c}0.00 \\
(0.00)\end{array}$ & $\begin{array}{c}0.00 \\
(0.00)\end{array}$ & $\begin{array}{c}0.00 \\
(0.00)\end{array}$ \\
\hline Law and order & $\begin{array}{l}-0.04^{* *} \\
(0.01)\end{array}$ & $\begin{array}{l}-0.00 \\
(0.01)\end{array}$ & $\begin{array}{l}-0.01 \\
(0.01)\end{array}$ & $\begin{array}{c}0.01 \\
(0.02)\end{array}$ \\
\hline $\begin{array}{l}\text { Industry, tourism } \\
\text { and agriculture }\end{array}$ & $\begin{array}{c}0.00 \\
(0.00)\end{array}$ & $\begin{array}{c}0.00 \\
(0.00)\end{array}$ & $\begin{array}{c}0.00 \\
(0.00)\end{array}$ & $\begin{array}{l}-0.00 \\
(0.00)\end{array}$ \\
\hline $\begin{array}{l}\text { City planning and } \\
\text { housing }\end{array}$ & $\begin{array}{l}-0.01 \\
(0.01)\end{array}$ & $\begin{array}{c}0.00 \\
(0.00)\end{array}$ & $\begin{array}{c}0.00 \\
(0.01)\end{array}$ & $\begin{array}{c}0.01 \\
(0.01)\end{array}$ \\
\hline Transports & 0.01 & -0.00 & -0.01 & -0.01 \\
\hline
\end{tabular}




\begin{tabular}{lcccc} 
& $(0.01)$ & $(0.00)$ & $(0.01)$ & $(0.01)$ \\
Share of 65+ & -0.16 & 0.02 & -0.03 & $0.94^{* * *}$ \\
& $(0.18)$ & $(0.12)$ & $(0.15)$ & $(0.27)$ \\
Population density & $0.03^{* * *}$ & -0.00 & 0.00 & -0.01 \\
& $(0.01)$ & $(0.01)$ & $(0.01)$ & $(0.01)$ \\
Unemployment rate & 0.12 & -0.02 & -0.02 & -0.27 \\
& $(0.15)$ & $(0.07)$ & $(0.09)$ & $(0.16)$ \\
Share of pop. with & $2.42^{* * *}$ & $-2.57^{* * *}$ & $-2.44^{* * *}$ & $-2.41^{* * *}$ \\
tertiary degree & $(0.50)$ & $(0.44)$ & $(0.50)$ & $(0.65)$ \\
Share of foreign & -0.29 & $0.22^{*}$ & 0.22 & $0.55^{* *}$ \\
pop. & $(0.15)$ & $(0.10)$ & $(0.12)$ & $(0.20)$ \\
\hline $\mathrm{N}$ & 2271 & 2271 & 2271 & 2271 \\
$\mathrm{r} 2$ & 0.96 & 0.98 & 0.98 & 0.99 \\
\hline $\mathrm{Cl}$
\end{tabular}

Clustered standard errors in parenthesis

$* \mathrm{p}<0.05,{ }^{* *} \mathrm{p}<0.01, * * * \mathrm{p}<0.001$ 
Table 11: Regression results for hypotheses $4 \mathrm{a}$ and $4 \mathrm{~b}$ (all national elections).

\begin{tabular}{|c|c|c|c|c|}
\hline & $\begin{array}{c}(1) \\
\text { Center-left }\end{array}$ & $\begin{array}{c}(2) \\
\text { League }\end{array}$ & $\begin{array}{c}\text { (3) } \\
\text { Populist } \\
\text { radical right }\end{array}$ & $\begin{array}{c}\text { (4) } \\
\text { Populist } \\
\text { parties }\end{array}$ \\
\hline $\begin{array}{l}\text { Austerity } \\
\text { dummy=1 \# Local } \\
\text { Gini }\end{array}$ & $\begin{array}{l}-20.21 \\
(12.69)\end{array}$ & $\begin{array}{l}10.31 \\
(5.92)\end{array}$ & $\begin{array}{l}17.82^{*} \\
(7.52)\end{array}$ & $\begin{array}{l}37.55^{* *} \\
(12.41)\end{array}$ \\
\hline $\begin{array}{l}\text { Austerity } \\
\text { dummy=1 \# Per- } \\
\text { capita taxable } \\
\text { income }\end{array}$ & $\begin{array}{l}-0.00 \\
(0.00)\end{array}$ & $\begin{array}{c}0.00 \\
(0.00)\end{array}$ & $\begin{array}{l}-0.00 \\
(0.00)\end{array}$ & $\begin{array}{c}0.00 \\
(0.00)\end{array}$ \\
\hline $\begin{array}{l}\text { Austerity } \\
\text { dummy=1 \# Share } \\
\text { of } 65+\end{array}$ & $\begin{array}{c}0.05 \\
(0.08)\end{array}$ & $\begin{array}{l}0.25^{* * *} \\
(0.05)\end{array}$ & $\begin{array}{l}0.30^{* * *} \\
(0.06)\end{array}$ & $\begin{array}{c}0.12 \\
(0.09)\end{array}$ \\
\hline $\begin{array}{l}\text { Austerity } \\
\text { dummy }=1 \text { \# } \\
\text { Population density }\end{array}$ & $\begin{array}{c}0.00 \\
(0.00)\end{array}$ & $\begin{array}{l}-0.00 \\
(0.00)\end{array}$ & $\begin{array}{l}-0.00 \\
(0.00)\end{array}$ & $\begin{array}{c}0.00 \\
(0.00)\end{array}$ \\
\hline $\begin{array}{l}\text { Austerity } \\
\text { dummy }=1 \# \\
\text { Unemployment rate }\end{array}$ & $\begin{array}{c}-0.42^{* * *} \\
(0.12)\end{array}$ & $\begin{array}{l}0.14^{* *} \\
(0.04)\end{array}$ & $\begin{array}{l}0.15^{*} \\
(0.06)\end{array}$ & $\begin{array}{l}0.38^{* * *} \\
(0.11)\end{array}$ \\
\hline $\begin{array}{l}\text { Austerity } \\
\text { dummy=1 \# Share } \\
\text { of pop. with tertiary } \\
\text { degree }\end{array}$ & $\begin{array}{l}-0.38^{*} \\
(0.15)\end{array}$ & $\begin{array}{l}0.44^{* * *} \\
(0.08)\end{array}$ & $\begin{array}{l}0.38^{* * *} \\
(0.09)\end{array}$ & $\begin{array}{l}0.32^{*} \\
(0.15)\end{array}$ \\
\hline $\begin{array}{l}\text { Austerity } \\
\text { dummy=1 \# Share } \\
\text { of foreign pop. }\end{array}$ & $\begin{array}{l}-0.03 \\
(0.08)\end{array}$ & $\begin{array}{l}-0.04 \\
(0.06)\end{array}$ & $\begin{array}{l}-0.00 \\
(0.07)\end{array}$ & $\begin{array}{l}-0.04 \\
(0.11)\end{array}$ \\
\hline Local Gini & $\begin{array}{l}36.53^{* *} \\
(13.89)\end{array}$ & $\begin{array}{c}-21.64^{* * *} \\
(6.52)\end{array}$ & $\begin{array}{c}-32.71^{* * *} \\
(7.92)\end{array}$ & $\begin{array}{c}-58.52^{* * *} \\
(15.01)\end{array}$ \\
\hline $\begin{array}{l}\text { Per-capita taxable } \\
\text { income }\end{array}$ & $\begin{array}{l}0.00^{* * *} \\
(0.00)\end{array}$ & $\begin{array}{l}-0.00^{* *} \\
(0.00)\end{array}$ & $\begin{array}{l}-0.00^{*} \\
(0.00)\end{array}$ & $\begin{array}{c}-0.00^{* * *} \\
(0.00)\end{array}$ \\
\hline Share of $65+$ & $\begin{array}{c}0.09 \\
(0.22)\end{array}$ & $\begin{array}{l}-0.26 \\
(0.19)\end{array}$ & $\begin{array}{l}-0.29 \\
(0.23)\end{array}$ & $\begin{array}{c}0.31 \\
(0.24)\end{array}$ \\
\hline Population density & $\begin{array}{l}0.02^{*} \\
(0.01)\end{array}$ & $\begin{array}{c}0.00 \\
(0.00)\end{array}$ & $\begin{array}{c}0.00 \\
(0.00)\end{array}$ & $\begin{array}{l}-0.01 \\
(0.01)\end{array}$ \\
\hline Unemployment rate & $\begin{array}{c}0.35 \\
(0.19)\end{array}$ & $\begin{array}{l}-0.05 \\
(0.10)\end{array}$ & $\begin{array}{l}-0.05 \\
(0.13)\end{array}$ & $\begin{array}{l}-0.33^{*} \\
(0.16)\end{array}$ \\
\hline $\begin{array}{l}\text { Share of pop. with } \\
\text { tertiary degree } \\
\text { Share of foreign } \\
\text { pop. }\end{array}$ & $\begin{array}{l}3.07^{* * *} \\
(0.45) \\
-0.08 \\
(0.15) \\
\end{array}$ & $\begin{array}{c}-5.01^{* * *} \\
(0.51) \\
0.41^{* *} \\
(0.15) \\
\end{array}$ & $\begin{array}{c}-4.88^{* * *} \\
(0.55) \\
0.50^{* *} \\
(0.17) \\
\end{array}$ & $\begin{array}{c}-4.90^{* * *} \\
(0.54) \\
0.55^{* *} \\
(0.18) \\
\end{array}$ \\
\hline $\begin{array}{l}\mathrm{N} \\
\mathrm{r} 2\end{array}$ & $\begin{array}{l}2819 \\
0.94\end{array}$ & $\begin{array}{c}2819 \\
0.98\end{array}$ & $\begin{array}{c}2819 \\
0.98\end{array}$ & $\begin{array}{c}2819 \\
0.98\end{array}$ \\
\hline
\end{tabular}

Clustered standard errors in parenthesis

$* \mathrm{p}<0.05, * * \mathrm{p}<0.01, * * * \mathrm{p}<0.001$ 
Table 12: Regression results for hypothesis $5 b$ - Economic dimension

\begin{tabular}{|c|c|c|c|c|}
\hline & $\begin{array}{c}\text { (1) } \\
\text { Econ cleavage }\end{array}$ & $\begin{array}{c}(2) \\
\text { Econ cleavage }\end{array}$ & $\begin{array}{c}(3) \\
\text { Econ cleavage }\end{array}$ & $\begin{array}{c}\text { (4) } \\
\text { Econ cleavage }\end{array}$ \\
\hline Age & $\begin{array}{l}0.00^{* * *} \\
(0.00)\end{array}$ & $\begin{array}{l}0.00^{* * *} \\
(0.00)\end{array}$ & $\begin{array}{l}0.00^{* * *} \\
(0.00)\end{array}$ & $\begin{array}{l}0.00^{* * *} \\
(0.00)\end{array}$ \\
\hline Clerks & $\begin{array}{c}-0.23^{* * * *} \\
(0.04)\end{array}$ & $\begin{array}{c}-0.23^{* * * *} \\
(0.04)\end{array}$ & $\begin{array}{c}-0.23^{* * *} \\
(0.04)\end{array}$ & $\begin{array}{c}-0.23^{* * *} \\
(0.04)\end{array}$ \\
\hline Unemp/Prec. & $\begin{array}{c}-0.23^{* * *} \\
(0.04)\end{array}$ & $\begin{array}{c}-0.23^{* * *} \\
(0.04)\end{array}$ & $\begin{array}{c}-0.23^{* * *} \\
(0.04)\end{array}$ & $\begin{array}{c}-0.23^{* * *} \\
(0.04)\end{array}$ \\
\hline Homemaker & $\begin{array}{c}-0.16^{* * * *} \\
(0.05)\end{array}$ & $\begin{array}{l}-0.16^{* * *} \\
(0.05)\end{array}$ & $\begin{array}{c}-0.16^{* * *} \\
(0.05)\end{array}$ & $\begin{array}{c}-0.16^{* * * *} \\
(0.05)\end{array}$ \\
\hline Retired & $\begin{array}{c}-0.24^{* * *} \\
(0.04)\end{array}$ & $\begin{array}{l}-0.24^{* * *} \\
(0.04)\end{array}$ & $\begin{array}{c}-0.24^{* * *} \\
(0.04)\end{array}$ & $\begin{array}{c}-0.24^{* * *} \\
(0.04)\end{array}$ \\
\hline Employers & $\begin{array}{l}0.19^{* * *} \\
(0.05)\end{array}$ & $\begin{array}{l}0.19^{* * *} \\
(0.05)\end{array}$ & $\begin{array}{l}0.19^{* * *} \\
(0.05)\end{array}$ & $\begin{array}{l}0.19^{* * *} \\
(0.05)\end{array}$ \\
\hline Teachers & $\begin{array}{c}-0.30^{* * *} \\
(0.05)\end{array}$ & $\begin{array}{c}-0.30^{* * *} \\
(0.05)\end{array}$ & $\begin{array}{c}-0.30^{* * *} \\
(0.05)\end{array}$ & $\begin{array}{c}-0.30^{* * *} \\
(0.05)\end{array}$ \\
\hline Small B.O & $\begin{array}{l}0.11^{*} \\
(0.05)\end{array}$ & $\begin{array}{l}0.11^{*} \\
(0.05)\end{array}$ & $\begin{array}{l}0.11^{*} \\
(0.05)\end{array}$ & $\begin{array}{l}0.11^{*} \\
(0.05)\end{array}$ \\
\hline Students & $\begin{array}{c}-0.18^{* * *} \\
(0.04)\end{array}$ & $\begin{array}{c}-0.18^{* * *} \\
(0.04)\end{array}$ & $\begin{array}{c}-0.18^{* * *} \\
(0.04)\end{array}$ & $\begin{array}{c}-0.18^{* * *} \\
(0.04)\end{array}$ \\
\hline Manual workers & $\begin{array}{c}-0.35^{* * *} \\
(0.04)\end{array}$ & $\begin{array}{c}-0.35^{* * *} \\
(0.04)\end{array}$ & $\begin{array}{c}-0.35^{* * *} \\
(0.04)\end{array}$ & $\begin{array}{c}-0.35^{* * *} \\
(0.04)\end{array}$ \\
\hline Tertiary & $\begin{array}{l}0.06^{* *} \\
(0.02)\end{array}$ & $\begin{array}{l}0.06^{* *} \\
(0.02)\end{array}$ & $\begin{array}{l}0.06^{* *} \\
(0.02)\end{array}$ & $\begin{array}{l}0.06^{* *} \\
(0.02)\end{array}$ \\
\hline Primary & $\begin{array}{c}-0.12^{* * * *} \\
(0.02)\end{array}$ & $\begin{array}{c}-0.12^{* * * *} \\
(0.02)\end{array}$ & $\begin{array}{c}-0.13^{* * * *} \\
(0.02)\end{array}$ & $\begin{array}{c}-0.12^{* * * *} \\
(0.02)\end{array}$ \\
\hline Female & $\begin{array}{c}-0.14^{* * *} \\
(0.01)\end{array}$ & $\begin{array}{c}-0.14^{* * *} \\
(0.01)\end{array}$ & $\begin{array}{c}-0.14^{* * *} \\
(0.01)\end{array}$ & $\begin{array}{c}-0.14^{* * *} \\
(0.01)\end{array}$ \\
\hline $\begin{array}{l}\text { Per-capita local } \\
\text { current spending }\end{array}$ & $\begin{array}{l}-0.05 \\
(0.05)\end{array}$ & & & \\
\hline Unemployment rate & $\begin{array}{l}-0.00 \\
(0.00)\end{array}$ & $\begin{array}{l}-0.00 \\
(0.00)\end{array}$ & $\begin{array}{l}-0.00 \\
(0.00)\end{array}$ & $\begin{array}{l}-0.00 \\
(0.00)\end{array}$ \\
\hline $\begin{array}{l}\text { Share of foreign } \\
\text { pop. }\end{array}$ & $\begin{array}{c}0.45 \\
(0.47)\end{array}$ & $\begin{array}{c}0.40 \\
(0.46)\end{array}$ & $\begin{array}{c}0.32 \\
(0.45)\end{array}$ & $\begin{array}{c}0.35 \\
(0.45)\end{array}$ \\
\hline Population density & $\begin{array}{l}-0.00 \\
(0.00)\end{array}$ & $\begin{array}{l}-0.00^{*} \\
(0.00)\end{array}$ & $\begin{array}{l}-0.00^{*} \\
(0.00)\end{array}$ & $\begin{array}{l}-0.00^{*} \\
(0.00)\end{array}$ \\
\hline $\begin{array}{l}\text { Per-capita taxable } \\
\text { income }\end{array}$ & $\begin{array}{l}0.00^{*} \\
(0.00)\end{array}$ & $\begin{array}{l}0.00^{*} \\
(0.00)\end{array}$ & $\begin{array}{c}0.00 \\
(0.00)\end{array}$ & $\begin{array}{c}0.00 \\
(0.00)\end{array}$ \\
\hline $\begin{array}{l}\text { Per-capita local } \\
\text { current spending } \\
\text { (2008-2018 diff.) }\end{array}$ & & $\begin{array}{l}-0.07 \\
(0.09)\end{array}$ & & \\
\hline Local gini coeff. & & & $\begin{array}{c}0.00 \\
(0.05)\end{array}$ & \\
\hline $\begin{array}{l}\text { Local gini coeff. } \\
\text { (2008-2018 diff.) }\end{array}$ & & & & $\begin{array}{c}0.16 \\
(0.20)\end{array}$ \\
\hline $\begin{array}{l}\mathrm{N} \\
\mathrm{r} 2\end{array}$ & $\begin{array}{c}61869 \\
0.12 \\
\end{array}$ & $\begin{array}{c}61869 \\
0.12\end{array}$ & $\begin{array}{c}61869 \\
0.12\end{array}$ & $\begin{array}{c}61869 \\
0.12 \\
\end{array}$ \\
\hline
\end{tabular}

Clustered standard errors in parenthesis

$* \mathrm{p}<0.05,{ }^{* *} \mathrm{p}<0.01, * * * \mathrm{p}<0.001$ 
Table 12: Regression results for hypothesis $5 \mathrm{~b}-$ Cultural dimension

\begin{tabular}{|c|c|c|c|c|}
\hline & $\begin{array}{c}(1) \\
\text { Cultural } \\
\text { cleavage }\end{array}$ & $\begin{array}{c}(2) \\
\text { Cultural } \\
\text { cleavage }\end{array}$ & $\begin{array}{c}(3) \\
\text { Cultural } \\
\text { cleavage }\end{array}$ & $\begin{array}{c}\text { (4) } \\
\text { Cultural } \\
\text { cleavage }\end{array}$ \\
\hline Age & $-0.00^{* * * *}$ & $-0.00^{* * * *}$ & $-0.00^{* * * *}$ & $\begin{array}{l}-0.00^{* * *} \\
(000)\end{array}$ \\
\hline Clerks & $\begin{array}{l}0.11^{*} \\
(0.05)\end{array}$ & $\begin{array}{l}0.11^{*} \\
(0.05)\end{array}$ & $\begin{array}{l}0.11^{*} \\
(0.05)\end{array}$ & $0.11^{*}$ \\
\hline Unemp/Prec. & $\begin{array}{l}0.17^{* * *} \\
(0.05)\end{array}$ & $\begin{array}{l}0.17^{* * *} \\
(0.05)\end{array}$ & $\begin{array}{l}0.17^{* * *} \\
(0.05)\end{array}$ & $\begin{array}{l}0.16^{* *} \\
(0.05)\end{array}$ \\
\hline Homemaker & $\begin{array}{l}-0.04 \\
(0.06)\end{array}$ & $\begin{array}{l}-0.04 \\
(0.06)\end{array}$ & $\begin{array}{l}-0.04 \\
(0.06)\end{array}$ & $\begin{array}{l}-0.05 \\
(0.06)\end{array}$ \\
\hline Retired & $\begin{array}{l}0.19^{* * *} \\
(0.05)\end{array}$ & $\begin{array}{l}0.19^{* * *} \\
(0.05)\end{array}$ & $\begin{array}{l}0.19^{* * *} \\
(0.05)\end{array}$ & $\begin{array}{l}0.18^{* * *} \\
(0.05)\end{array}$ \\
\hline Employers & $\begin{array}{l}-0.11^{*} \\
(0.05)\end{array}$ & $\begin{array}{l}-0.11^{*} \\
(0.05)\end{array}$ & $\begin{array}{l}-0.11^{*} \\
(0.05)\end{array}$ & $\begin{array}{l}-0.11^{*} \\
(0.05)\end{array}$ \\
\hline Teachers & $\begin{array}{l}0.14^{*} \\
(0.06)\end{array}$ & $\begin{array}{l}0.14^{*} \\
(0.06)\end{array}$ & $\begin{array}{l}0.14^{*} \\
(0.06)\end{array}$ & $\begin{array}{l}0.14^{*} \\
(0.06)\end{array}$ \\
\hline Small B.O & $\begin{array}{l}-0.07 \\
(0.06)\end{array}$ & $\begin{array}{l}-0.07 \\
(0.06)\end{array}$ & $\begin{array}{l}-0.07 \\
(0.06)\end{array}$ & $\begin{array}{l}-0.07 \\
(0.06)\end{array}$ \\
\hline Students & $\begin{array}{l}0.19^{* * *} \\
(0.05)\end{array}$ & $\begin{array}{l}0.19^{* * *} \\
(0.05)\end{array}$ & $\begin{array}{l}0.19^{* * *} \\
(0.05)\end{array}$ & $\begin{array}{l}0.19^{* * *} \\
(0.05)\end{array}$ \\
\hline Manual workers & $\begin{array}{c}0.00 \\
(0.05)\end{array}$ & $\begin{array}{c}0.00 \\
(0.05)\end{array}$ & $\begin{array}{c}0.00 \\
(0.05)\end{array}$ & $\begin{array}{l}0.00 \\
(0.05)\end{array}$ \\
\hline Tertiary & $\begin{array}{l}0.16^{* * *} \\
(0.02)\end{array}$ & $\begin{array}{l}0.16^{* * *} \\
(0.02)\end{array}$ & $\begin{array}{l}0.16^{* * *} \\
(0.02)\end{array}$ & $\begin{array}{l}0.16^{* * *} \\
(0.02)\end{array}$ \\
\hline Primary & $\begin{array}{c}-0.11^{* * *} \\
(0.02)\end{array}$ & $\begin{array}{c}-0.11^{* * *} \\
(0.02)\end{array}$ & $\begin{array}{c}-0.11^{* * *} \\
(0.02)\end{array}$ & $\begin{array}{c}-0.11^{* * *} \\
(0.02)\end{array}$ \\
\hline Female & $\begin{array}{l}0.19^{* * *} \\
(0.02)\end{array}$ & $\begin{array}{l}0.19^{* * *} \\
(0.02)\end{array}$ & $\begin{array}{c}0.19^{* * *} \\
(0.02)\end{array}$ & $\begin{array}{l}0.19^{* * *} \\
(0.02)\end{array}$ \\
\hline $\begin{array}{l}\text { Per-capita local } \\
\text { current spending }\end{array}$ & $\begin{array}{c}0.01 \\
(0.07)\end{array}$ & & & \\
\hline Unemployment rate & $\begin{array}{l}-0.01^{*} \\
(0.00)\end{array}$ & $\begin{array}{l}-0.01^{*} \\
(0.00)\end{array}$ & $\begin{array}{l}-0.01^{*} \\
(0.00)\end{array}$ & $\begin{array}{c}-0.01^{* *} \\
(0.00)\end{array}$ \\
\hline $\begin{array}{l}\text { Share of foreign } \\
\text { pop. }\end{array}$ & $\begin{array}{l}-0.60 \\
(0.61)\end{array}$ & $\begin{array}{l}-0.61 \\
(0.60)\end{array}$ & $\begin{array}{l}-0.56 \\
(0.59)\end{array}$ & $\begin{array}{l}-0.68 \\
(0.59)\end{array}$ \\
\hline Population density & $\begin{array}{c}0.00 \\
(0.00)\end{array}$ & $\begin{array}{c}0.00 \\
(0.00)\end{array}$ & $\begin{array}{c}0.00 \\
(0.00)\end{array}$ & $\begin{array}{c}0.00 \\
(0.00)\end{array}$ \\
\hline $\begin{array}{l}\text { Per-capita taxable } \\
\text { income }\end{array}$ & $\begin{array}{c}0.00 \\
(0.00)\end{array}$ & $\begin{array}{c}0.00 \\
(0.00)\end{array}$ & $\begin{array}{l}0.00 \\
(0.00)\end{array}$ & $\begin{array}{c}0.00 \\
(0.00)\end{array}$ \\
\hline $\begin{array}{l}\text { Per-capita local } \\
\text { current spending } \\
\text { (2008-2018 diff.) }\end{array}$ & & $\begin{array}{c}0.04 \\
(0.11)\end{array}$ & & \\
\hline Local gini coeff. & & & $\begin{array}{l}-0.00 \\
(0.07)\end{array}$ & \\
\hline $\begin{array}{l}\text { Local gini coeff. } \\
\text { (2008-2018 diff.) }\end{array}$ & & & & $\begin{array}{l}-0.15 \\
(0.26)\end{array}$ \\
\hline $\begin{array}{l}\mathrm{N} \\
\mathrm{r} 2\end{array}$ & $\begin{array}{c}61869 \\
0.07\end{array}$ & $\begin{array}{c}61869 \\
0.07\end{array}$ & $\begin{array}{c}61869 \\
0.07\end{array}$ & $\begin{array}{c}61869 \\
0.07\end{array}$ \\
\hline
\end{tabular}

Clustered standard errors in parenthesis

$* \mathrm{p}<0.05, * * \mathrm{p}<0.01, * * * \mathrm{p}<0.001$ 
Table 14: Regression results for hypothesis $5 b-$ Populist dimension

\begin{tabular}{|c|c|c|c|c|}
\hline & $\begin{array}{c}\text { (1) } \\
\text { Populist } \\
\text { cleavage }\end{array}$ & $\begin{array}{c}\text { (2) } \\
\text { Populist } \\
\text { cleavage }\end{array}$ & $\begin{array}{c}(3) \\
\text { Populist } \\
\text { cleavage }\end{array}$ & $\begin{array}{c}\text { (4) } \\
\text { Populist } \\
\text { cleavage }\end{array}$ \\
\hline Age & $\begin{array}{l}-0.00 \\
(0.00)\end{array}$ & $\begin{array}{l}-0.00 \\
(0.00)\end{array}$ & $\begin{array}{l}-0.00 \\
(0.00)\end{array}$ & $\begin{array}{l}-0.00 \\
(0.00)\end{array}$ \\
\hline Clerks & $\begin{array}{l}-0.04 \\
(0.05)\end{array}$ & $\begin{array}{l}-0.04 \\
(0.05)\end{array}$ & $\begin{array}{l}-0.04 \\
(0.05)\end{array}$ & $\begin{array}{l}-0.04 \\
(0.05)\end{array}$ \\
\hline Unemp/Prec. & $\begin{array}{l}-0.09 \\
(0.05)\end{array}$ & $\begin{array}{l}-0.09 \\
(0.05)\end{array}$ & $\begin{array}{l}-0.09 \\
(0.05)\end{array}$ & $\begin{array}{l}-0.09 \\
(0.05)\end{array}$ \\
\hline Homemaker & $\begin{array}{l}-0.12^{*} \\
(0.06)\end{array}$ & $\begin{array}{l}-0.12^{*} \\
(0.06)\end{array}$ & $\begin{array}{l}-0.12^{*} \\
(0.06)\end{array}$ & $\begin{array}{l}-0.12^{*} \\
(0.06)\end{array}$ \\
\hline Retired & $\begin{array}{c}0.07 \\
(0.05)\end{array}$ & $\begin{array}{c}0.07 \\
(0.05)\end{array}$ & $\begin{array}{c}0.07 \\
(0.05)\end{array}$ & $\begin{array}{c}0.07 \\
(0.05)\end{array}$ \\
\hline Employers & $\begin{array}{l}-0.02 \\
(0.05)\end{array}$ & $\begin{array}{l}-0.03 \\
(0.05)\end{array}$ & $\begin{array}{l}-0.02 \\
(0.05)\end{array}$ & $\begin{array}{l}-0.03 \\
(0.05)\end{array}$ \\
\hline Teachers & $\begin{array}{l}-0.03 \\
(0.06)\end{array}$ & $\begin{array}{l}-0.03 \\
(0.06)\end{array}$ & $\begin{array}{l}-0.03 \\
(0.06)\end{array}$ & $\begin{array}{l}-0.03 \\
(0.06)\end{array}$ \\
\hline Small B.O & $\begin{array}{l}-0.15^{* *} \\
(0.06)\end{array}$ & $\begin{array}{l}-0.15^{* *} \\
(0.06)\end{array}$ & $\begin{array}{l}-0.15^{* *} \\
(0.06)\end{array}$ & $\begin{array}{l}-0.16^{* *} \\
(0.06)\end{array}$ \\
\hline Students & $\begin{array}{l}0.15^{* *} \\
(0.05)\end{array}$ & $\begin{array}{l}0.15^{* *} \\
(0.05)\end{array}$ & $\begin{array}{l}0.16^{* *} \\
(0.05)\end{array}$ & $\begin{array}{l}0.15^{* *} \\
(0.05)\end{array}$ \\
\hline Manual workers & $\begin{array}{c}-0.25^{* * *} \\
(0.05)\end{array}$ & $\begin{array}{c}-0.25^{* * *} \\
(0.05)\end{array}$ & $\begin{array}{c}-0.25^{* * *} \\
(0.05)\end{array}$ & $\begin{array}{c}-0.25^{* * *} \\
(0.05)\end{array}$ \\
\hline Tertiary & $\begin{array}{l}0.28^{* * *} \\
(0.02)\end{array}$ & $\begin{array}{l}0.28^{* * *} \\
(0.02)\end{array}$ & $\begin{array}{l}0.28^{* * *} \\
(0.02)\end{array}$ & $\begin{array}{l}0.28^{* * *} \\
(0.02)\end{array}$ \\
\hline Primary & $\begin{array}{c}-0.12^{* * * *} \\
(0.02)\end{array}$ & $\begin{array}{c}-0.12^{* * * *} \\
(0.02)\end{array}$ & $\begin{array}{c}-0.12^{* * *} \\
(0.02)\end{array}$ & $\begin{array}{c}-0.13^{* * *} \\
(0.02)\end{array}$ \\
\hline Female & $\begin{array}{l}-0.03 \\
(0.02)\end{array}$ & $\begin{array}{l}-0.03 \\
(0.02)\end{array}$ & $\begin{array}{l}-0.03 \\
(0.02)\end{array}$ & $\begin{array}{l}-0.03 \\
(0.02)\end{array}$ \\
\hline $\begin{array}{l}\text { Per-capita local } \\
\text { current spending }\end{array}$ & $\begin{array}{c}0.07 \\
(0.07)\end{array}$ & & & \\
\hline Unemployment rate & $\begin{array}{l}-0.01^{* *} \\
(0.00)\end{array}$ & $\begin{array}{l}-0.01^{* *} \\
(0.00)\end{array}$ & $\begin{array}{l}-0.01^{*} \\
(0.00)\end{array}$ & $\begin{array}{l}-0.01^{* *} \\
(0.00)\end{array}$ \\
\hline $\begin{array}{l}\text { Share of foreign } \\
\text { pop. }\end{array}$ & $\begin{array}{c}0.93 \\
(0.65)\end{array}$ & $\begin{array}{c}1.07 \\
(0.64)\end{array}$ & $\begin{array}{c}0.98 \\
(0.62)\end{array}$ & $\begin{array}{l}1.05 \\
(0.63)\end{array}$ \\
\hline Population density & $\begin{array}{l}-0.00 \\
(0.00)\end{array}$ & $\begin{array}{c}0.00 \\
(0.00)\end{array}$ & $\begin{array}{l}-0.00 \\
(0.00)\end{array}$ & $\begin{array}{c}0.00 \\
(0.00)\end{array}$ \\
\hline $\begin{array}{l}\text { Per-capita taxable } \\
\text { income }\end{array}$ & $\begin{array}{c}0.00 \\
(0.00)\end{array}$ & $\begin{array}{c}0.00 \\
(0.00)\end{array}$ & $\begin{array}{c}0.00 \\
(0.00)\end{array}$ & $\begin{array}{c}0.00 \\
(0.00)\end{array}$ \\
\hline $\begin{array}{l}\text { Per-capita local } \\
\text { current spending } \\
\text { (2008-2018 diff.) }\end{array}$ & & $\begin{array}{c}0.02 \\
(0.12)\end{array}$ & & \\
\hline Local gini coeff. & & & $\begin{array}{l}-0.12 \\
(0.07)\end{array}$ & \\
\hline $\begin{array}{l}\text { Local gini coeff. } \\
\text { (2008-2018 diff.) }\end{array}$ & & & & $\begin{array}{l}-0.27 \\
(0.26)\end{array}$ \\
\hline $\begin{array}{l}\mathrm{N} \\
\mathrm{r} 2\end{array}$ & $\begin{array}{c}61869 \\
0.07\end{array}$ & $\begin{array}{c}61869 \\
0.07\end{array}$ & $\begin{array}{c}61869 \\
0.07\end{array}$ & $\begin{array}{c}61869 \\
0.07\end{array}$ \\
\hline
\end{tabular}

Clustered standard errors in parenthesis

$* \mathrm{p}<0.05, * * \mathrm{p}<0.01, * * * \mathrm{p}<0.001$ 
Table 14: Regression results for hypothesis $5 b$ - Transnational dimension

\begin{tabular}{|c|c|c|c|c|}
\hline & $\begin{array}{c}(1) \\
\text { Transnational } \\
\text { cleavage }\end{array}$ & $\begin{array}{c}(2) \\
\text { Transnational } \\
\text { cleavage }\end{array}$ & $\begin{array}{c}(3) \\
\text { Transnational } \\
\text { cleavage }\end{array}$ & $\begin{array}{c}(4) \\
\text { Transnational } \\
\text { cleavage }\end{array}$ \\
\hline Age & $0.00^{* * *}$ & $0.00^{* * *}$ & $0.00^{* * *}$ & $0.00^{* * *}$ \\
\hline Clerks & $\begin{array}{c}(0.00) \\
0.05 \\
(0.05)\end{array}$ & $\begin{array}{c}(0.00) \\
0.05 \\
(0.05)\end{array}$ & $\begin{array}{c}(0.00) \\
0.05 \\
(0.05)\end{array}$ & $\begin{array}{c}(0.00) \\
0.05 \\
(0.05)\end{array}$ \\
\hline Unemp/Prec. & $\begin{array}{c}0.07 \\
(0.05)\end{array}$ & $\begin{array}{c}0.07 \\
(0.05)\end{array}$ & $\begin{array}{c}0.07 \\
(0.05)\end{array}$ & $\begin{array}{c}0.07 \\
(0.05)\end{array}$ \\
\hline Homemaker & $\begin{array}{l}0.15^{*} \\
(0.06)\end{array}$ & $\begin{array}{l}0.15^{*} \\
(0.06)\end{array}$ & $\begin{array}{l}0.15^{*} \\
(0.06)\end{array}$ & $\begin{array}{l}0.15^{*} \\
(0.06)\end{array}$ \\
\hline Retired & $\begin{array}{l}-0.14^{*} \\
(0.06)\end{array}$ & $\begin{array}{l}-0.14^{*} \\
(0.06)\end{array}$ & $\begin{array}{l}-0.14^{*} \\
(0.06)\end{array}$ & $\begin{array}{l}-0.14^{*} \\
(0.06)\end{array}$ \\
\hline Employers & $\begin{array}{c}0.05 \\
(0.06)\end{array}$ & $\begin{array}{c}0.05 \\
(0.06)\end{array}$ & $\begin{array}{c}0.05 \\
(0.06)\end{array}$ & $\begin{array}{c}0.06 \\
(0.06)\end{array}$ \\
\hline Teachers & $\begin{array}{l}-0.04 \\
(0.06)\end{array}$ & $\begin{array}{l}-0.04 \\
(0.06)\end{array}$ & $\begin{array}{l}-0.04 \\
(0.06)\end{array}$ & $\begin{array}{l}-0.04 \\
(0.06)\end{array}$ \\
\hline Small B.O & $\begin{array}{l}0.20^{* *} \\
(0.06)\end{array}$ & $\begin{array}{l}0.20^{* *} \\
(0.06)\end{array}$ & $\begin{array}{l}0.20^{* *} \\
(0.06)\end{array}$ & $\begin{array}{l}0.20^{* *} \\
(0.06)\end{array}$ \\
\hline Students & $\begin{array}{c}-0.22^{* * *} \\
(0.06)\end{array}$ & $\begin{array}{c}-0.22^{* * * *} \\
(0.06)\end{array}$ & $\begin{array}{c}-0.22^{* * *} \\
(0.06)\end{array}$ & $\begin{array}{c}-0.22^{* * *} \\
(0.06)\end{array}$ \\
\hline Manual workers & $\begin{array}{l}0.22^{* * *} \\
(0.06)\end{array}$ & $\begin{array}{l}0.22^{* * *} \\
(0.06)\end{array}$ & $\begin{array}{l}0.22^{* * * *} \\
(0.06)\end{array}$ & $\begin{array}{l}0.22^{* * * *} \\
(0.06)\end{array}$ \\
\hline Tertiary & $\begin{array}{c}-0.25^{* * *} \\
(0.02)\end{array}$ & $\begin{array}{c}-0.25^{* * * *} \\
(0.02)\end{array}$ & $\begin{array}{c}-0.25^{* * *} \\
(0.02)\end{array}$ & $\begin{array}{c}-0.25^{* * *} \\
(0.02)\end{array}$ \\
\hline Primary & $\begin{array}{l}0.16^{* * *} \\
(0.02)\end{array}$ & $\begin{array}{l}0.16^{* * *} \\
(0.02)\end{array}$ & $\begin{array}{l}0.16^{* * * *} \\
(0.02)\end{array}$ & $\begin{array}{l}0.16^{* * *} \\
(0.02)\end{array}$ \\
\hline Female & $\begin{array}{c}-0.08^{* * *} \\
(0.02)\end{array}$ & $\begin{array}{c}-0.08^{* * *} \\
(0.02)\end{array}$ & $\begin{array}{c}-0.08^{* * *} \\
(0.02)\end{array}$ & $\begin{array}{c}-0.09^{* * *} \\
(0.02)\end{array}$ \\
\hline $\begin{array}{l}\text { Per-capita local } \\
\text { current spending }\end{array}$ & $\begin{array}{l}-0.04 \\
(0.08)\end{array}$ & & & \\
\hline Unemployment rate & $\begin{array}{c}0.01^{*} \\
(0.00)\end{array}$ & $\begin{array}{c}0.01^{*} \\
(0.00)\end{array}$ & $\begin{array}{l}0.01^{* *} \\
(0.00)\end{array}$ & $\begin{array}{l}0.01^{* *} \\
(0.00)\end{array}$ \\
\hline $\begin{array}{l}\text { Share of foreign } \\
\text { pop. }\end{array}$ & $\begin{array}{c}0.95 \\
(0.67)\end{array}$ & $\begin{array}{c}0.92 \\
(0.65)\end{array}$ & $\begin{array}{c}0.80 \\
(0.64)\end{array}$ & $\begin{array}{c}0.95 \\
(0.64)\end{array}$ \\
\hline Population density & $\begin{array}{l}-0.00 \\
(0.00)\end{array}$ & $\begin{array}{l}-0.00 \\
(0.00)\end{array}$ & $\begin{array}{l}-0.00 \\
(0.00)\end{array}$ & $\begin{array}{l}-0.00 \\
(0.00)\end{array}$ \\
\hline $\begin{array}{l}\text { Per-capita taxable } \\
\text { income }\end{array}$ & $\begin{array}{l}-0.00 \\
(0.00)\end{array}$ & $\begin{array}{l}-0.00 \\
(0.00)\end{array}$ & $\begin{array}{l}-0.00 \\
(0.00)\end{array}$ & $\begin{array}{l}-0.00 \\
(0.00)\end{array}$ \\
\hline $\begin{array}{l}\text { Per-capita local } \\
\text { current spending } \\
\text { (2008-2018 diff.) }\end{array}$ & & $\begin{array}{l}-0.05 \\
(0.12)\end{array}$ & & \\
\hline Local gini coeff. & & & $\begin{array}{l}-0.06 \\
(0.07)\end{array}$ & \\
\hline $\begin{array}{l}\text { Local gini coeff. } \\
\text { (2008-2018 diff.) }\end{array}$ & & & & $\begin{array}{c}0.51 \\
(0.26)\end{array}$ \\
\hline $\begin{array}{l}\mathrm{N} \\
\mathrm{r} 2\end{array}$ & $\begin{array}{c}61869 \\
0.08\end{array}$ & $\begin{array}{c}61869 \\
0.08\end{array}$ & $\begin{array}{c}61869 \\
0.08\end{array}$ & $\begin{array}{c}61869 \\
0.08\end{array}$ \\
\hline
\end{tabular}

Clustered standard errors in parenthesis

$* \mathrm{p}<0.05, * * \mathrm{p}<0.01, * * * \mathrm{p}<0.001$ 